\title{
Political Leadership after the British: A Study of Jomo Kenyatta and Julius Nyerere
}

\author{
By James Baigent
}

A thesis submitted to Victoria University of Wellington in fulfilment of the requirements for the degree of Master of Arts in Political Science

Victoria University of Wellington

2013 
Contents

Introduction 6.

Chapter One - Literature Review 10.

Chapter Two - Jomo Kenyatta 45.

Chapter Three - Julius Nyerere 97.

Conclusion 142.

Bibliography 149. 


\section{Abstract}

In the post-World War Two era, political decolonisation swept across Africa. In the wake of decolonisation a wide variety of political leadership outcomes have emerged. In many national contexts indigenous political stakeholders were required to wrest political control from colonial powers. This study will compare the progress of the post-colonial political leadership experiences in Kenya and Tanzania - in order to ascertain the nature of the unique pressures and constraints placed upon first generation post-colonial political leaders. This will be framed and informed through the lens of contemporary and historical theories of leadership. Developing a greater understanding of the leadership experiences of these first-generation post decolonisation leaders will provide greater insight into the nature of post decolonisation leadership in sub-Saharan Africa. 
Abbreviations

FDI - Foreign Direct Investment

KANU - Kenya African National Union

KAU - Kenya African Union

KCA - Kikuyu Central Association

KPU - Kenya People's Union

RDA - Ruvuma Development Association

TAA - Tanganyikan African Association

TANU - Tanganyikan African National Union

TAWA - Tanganyikan African Welfare Association

UN - United Nations

UNDP - United Nations Development Programme UTP - United Tanganyika Party 


\section{Figures and Tables}

1.1 - The intersection of relevant literature to this thesis (Page 10)

4.1 - The imagined spectrum of political choices vs. the actual spectrum of choices available to leaders at independence (Page 147) 


\section{Introduction}

'Governments set up overnight, like everything in nature whose growth is forced, lack strong roots and ramifications. So they are destroyed in the first bad spell. This is inevitable unless those who have suddenly become princes are of such prowess that overnight they can learn how to preserve what fortune has suddenly tossed in their laps, and unless they can lay foundations such as other princes would have already been building on.' - Niccolo Machiavelli ${ }^{1}$

In the 1960s and 70's, a new generation of 'princes' inherited Africa. They inherited their political kingdoms from a raft of spent and retiring colonial powers. The British, French, Belgians and Portuguese were the last to retreat from Africa; Germany and Italy's retreat had been secured earlier. During the 'Scramble for Africa', commencing around a century before, the European powers laid claim to almost the entire continent. During the 'scramble', the various 'halls of power' in Western Europe saw the construction of crudely drawn maps of the continent, and the wholesale 'carving up' of one of the last frontiers of imperialism. Martin Meredith asserts that 'by the time the Scramble for Africa was over, some 10,000 African polities had been amalgamated into forty European colonies and protectorates. Thus were born the modern states of Africa. ${ }^{2}$

As the age of imperialism drew to a close, the colonial-state was to be replaced by the self-determined African nation-state. At the apex of these new states were the 'princes' referenced above. This thesis is a study not only of these 'princes', but the institutions and context that formed around them. It is a study of leadership; which is a dynamic relationship between the leader and their context. This is not a 'systems analysis' or a study of the unique institutional framework arising in Africa during the period of decolonisation - it is a study of the lead actors within the institutions. It also

\footnotetext{
${ }^{1}$ Machiavelli, Niccolo, The Prince, 1513, in Jackson, R., and Rosberg, C., Personal Rule in Black Africa, Berkeley, 1982, p. v.

${ }^{2}$ Meredith, Martin, The State of Africa - A History of Fifty Years of Independence, London, 2006, p. 2
} 
a study of the dynamic relationship between the actor's leadership and the wider political context or environment within which they operated. This environment or milieu was distinctively and powerfully framed by the colonial experience. The cases employed in this thesis are the leadership experiences of Jomo Kenyatta and Julius Nyerere. Both leaders were East African, and both inherited their leadership from the proud and expansive British Empire. The British approach to colonial establishment and governance did much to frame the leadership environment in which the selected actors operated. This thesis is therefore titled 'Political Leadership after the British: A Study of Jomo Kenyatta and Julius Nyerere.'

Untrained musings on African independence leadership can often conjure up crude references to the emergence of one party-states; or dictatorship, corruption, tribalism, civil conflict and a general plunder of the state's resources for enrichment of a few elites. In several cases there is a body of evidence that supports such accusations, however, to generalise on the state of all African political leadership, using these crude terms is inherently misguided and unhelpful. Joseph Mobutu can legitimately be referred to as 'the great plunderer,' in reference to his outrageous mismanagement of what is referred to today as the Democratic Republic of the Congo. ${ }^{3}$ The hubris of Ghana's Kwame Nkrumah also provides the untrained eye with evidence to support such generalisations; as could the bizarre and tyrannical leadership of Hastings Banda in Malawi. ${ }^{4}$ Whilst cases of significant political mismanagement were unfortunately recurrent among the cohort of independence leaders in Africa, this thesis finds no evidence to support any assertion that this was a continent-wide phenomenon. This

\footnotetext{
${ }^{3}$ Meredith, pp. $293-308$

${ }^{4}$ Ibid, p. 165
} 
thesis instead seeks to address the unique strengths and weaknesses of the leadership of the specific cases, within in their specific environments.

The British Empire manifested itself in a variety of ways depending on the location of operation. Analysis of the impact of British colonial practice on independence leadership must be measured in a way that acknowledges the significant variance and contradictions that existed within the British imperial system. This thesis analyses the political leadership of Jomo Kenyatta and Julius Nyerere, as impacted upon by their unique preceding British colonial systems. This analysis is done with a view to test the applicability of the political leadership theories advanced by James McGregor Burns and Frederick Greenstein. Both theorists have written extensively on political leadership at transitional moments in history, and advance different frameworks for the analysis of leadership behaviour. Both theorists place substantial emphasis on context, a bias that fits this thesis superbly well - as it is a study of leadership in context. Burns' contextual approach focuses heavily on the orientation of what he calls 'the followership'- that is the citizenry, the recipients of leadership. Greenstein's contextual analysis is broader. He calls for the researcher to assess the 'stability' of the entire environment that surrounds the leader. Greenstein also advises the researcher to look to the 'strategic location' of the actor as an important indicator of likely leadership outcomes. These ideas, and their relationship to British colonialism in Africa, will be developed much more thoroughly in the following chapter.

As noted, the British Empire forms much of the backdrop for this study. Generalisations about the nature of the British Empire can be as equally misguided and unhelpful as the aforementioned and inaccurate musings about independence governance. The British Empire cannot be analysed as a single unit. The following 
chapters dedicate considerable analysis to how the Empire manifested itself within different contexts; the forces that drove the differences, and how these manifestations subsequently framed the leadership equation. The body of literature available on the British Empire is of remarkable size, and within the large body there are a wide variety of perspectives that are often conflicting. A significant portion of the following chapter is therefore assigned to reviewing perspectives on the British Empire, so as to ensure it is represented accurately within the leadership equation that is projected to emerge from this thesis.

Following the analysis of literature on empire and the theoretical discussion on leadership, this thesis will then turn in subsequent chapters to the cases of Jomo Kenyatta and Julius Nyerere. The leadership experiences of the two individuals will be exposed in as much detail as possible so as to further illuminate the theoretical discussion on political leadership after the British in Africa. The narrative of their own political development and leadership practice is overlaid with the narrative of the British colonial operations in their own unique contexts. This should provide the necessary discussion of the inputs and outputs that make up the leadership equation this thesis seeks to expose. This will enable conclusions to be drawn on the dynamic nature of political leadership after the British in Africa; conclusions arising from the experiences of Jomo Kenyatta and Julius Nyerere. 


\section{Chapter One - Literature Review}

The most effective method for conceptualising the raft of literature that feeds into this thesis is to envisage a 'T-Intersection' where the three major channels are; literature on the British Empire, applicable political leadership theory and literature on independence African political leadership.

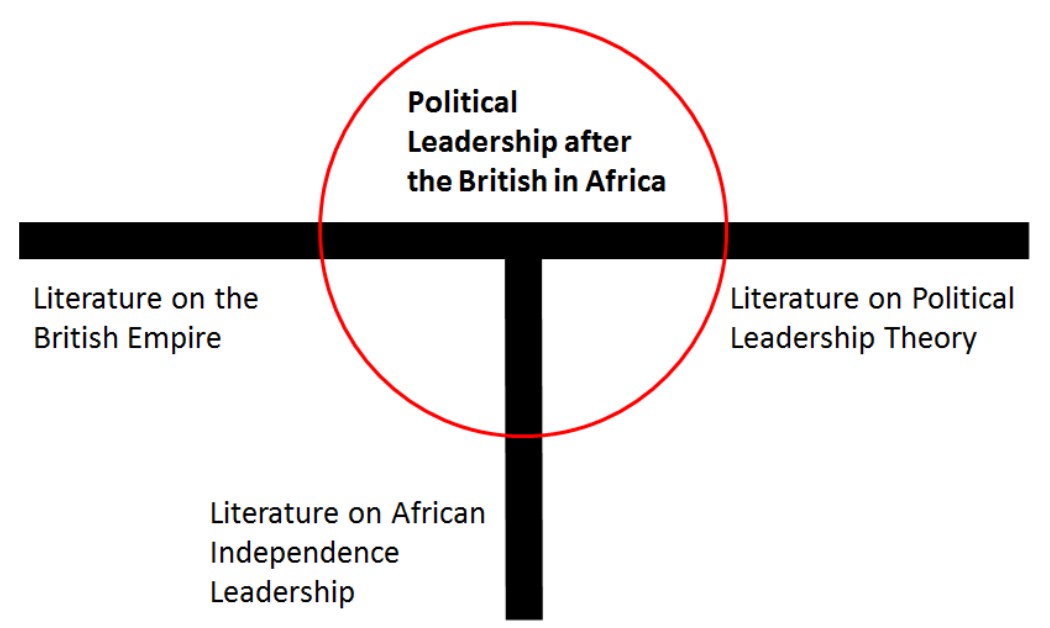

\section{Figure 1.1 - The intersection of relevant literature to this thesis}

Within these three major subject areas there are obviously a myriad of sub-groups of literature, for example specific biographies of subjects, studies of specific features of Empire, or different sub-strata of political leadership theory.

This literature review will commence with a review of the literature relevant to the subject's British Empire elements. This is the literature that focuses on British Imperial operations in Africa (with major reference to the subject countries). It covers everything from ideologies and theories of Empire to the plain statistics that articulate the story of British imperial activity. Useful starting points for this process are the general histories of Empire - such as Niall Ferguson's 'Empire - How Britain Made the Modern World,' or John Darwin's 'The Empire Project - The Rise and Fall of the British World System, 1830 - 1970.' Following the review of the generalist literature on the 
subject, detailed accounts on British imperial operations in the subject countries will be reviewed. Special attention will be paid to literature that focuses on the intersection between empire and indigenous leadership.

The subsequent phase of the review will be focused on the relevant political leadership theory. Frederick Greenstein's thesis on leadership in environments of high levels of restructuring has been deemed directly applicable to this subject - so therefore will be an important piece of theoretical literature to be reviewed. James McGregor Burns' analysis also provides a wealth of assistance to this thesis.

\section{Literature on the British Empire}

\section{The precursor to global capitalism}

One of the most prolific writers on this subject in recent times is Niall Ferguson. His two major texts on the subject are Empire - The Rise and Demise of the British World Order and the Lessons for Global Power and Empire- How Britain Made the Modern World. Ferguson is an economic historian with a specific focus on the history of financial markets. This naturally frames a considerable portion of his work within the parameters of economic thought. Ferguson's thesis rests on the principle that British Imperial success was in large part a result of the strength of the British Government's financial institutions - inherited and developed from the Dutch Imperial model that preceded them. ${ }^{5}$ Expanding from this premise Ferguson makes continual assertion that the financial paradigms which governed British Imperial thinking - established the context for the subsequent ascendency of modern global capitalism.

\footnotetext{
${ }^{5}$ Ferguson, Niall, Empire - How Britain Made the Modern World, London 2004, pp. 1 - 29
} 


\section{Ferguson and the 'night watchman' state}

Ferguson also displays a considerable amount of sympathy for an idea that the Viceroy of India Lord Curzon, articulated over one hundred years ago, that, 'the British Empire was the greatest force for good the world had ever seen ${ }^{6}$. Ferguson argues the British Empire was responsible for the dissemination of ideas of liberty, representative assemblies, the limited 'night watchman' state, Common Law and civilised forms of land tenure ${ }^{7}$ - among Britain's vast array of dominions, colonies, protectorates and spheres of influence. Ferguson's claims are buttressed by arguments around improvements in the health, education and infrastructural development in colonial society, when compared with pre-colonial times. This particular justification of Empire is naturally challenged by a multitude of authors. John Cartwright, author of Political Leadership in Africa, for example identifies the limited 'night watchman' state as one of the key contributing forces in the drift toward leadership problems that have been observed in the post-independence period. ${ }^{8}$ This theme has proven to be a major contributor to this thesis. Presumably because of Ferguson's affiliation to the economic theories of natural markets, he seems to believe that the limited 'night watchman' state was a positive British contribution to the nations of the Empire. Cartwright, however, asserts;

'Not only did the small size... of the civil service restrict its ability to generate and process the information that a [post-independence] ruler would need in order to canvass effectively a range of policy options, but the sheer mass of dayto-day demands meant that few leaders or their lieutenants had the time to take a long-range look at where they were going ${ }^{\prime}{ }^{9}$

\footnotetext{
${ }^{6}$ Schama, Simon, A History of Britain - The Fate of Empire 1776 - 2000, Volume Three, London, 2002

${ }^{7}$ Ferguson, p xxiii

${ }^{8}$ Cartwright, John, Political Leadership in Africa, Kent, 1983, p 58

${ }^{9}$ Ibid, p. 54
} 
Essentially Cartwright advances an alternative view to Ferguson's, that British policy makers did not bequeath the inheritors of their Empire an economically efficient and limited state apparatus -rather they handed them geographic colonial units with high levels of institutional weakness and deficit, which could be considered a contributor in any drift toward leadership problems.

\section{An evolving empire}

A key contribution of Ferguson to scholarship on the British Empire, in the same vein as Simon Schama and other Empire historians, is the identifying of different phases of ideology that informed and governed British Imperial policy. An example of this is the contrast between 'the Hanoverian' approach of 'grabbing power in Asia, land in America and slaves in Africa,' and the subsequent Victorian 'elevated aspirations. ${ }^{10}$ This is an essential consideration for this thesis as the ideology of the day in London went a long way to determining colonial practices in the subject cases. Ferguson does well to articulate the uniquely Victorian belief that British imperial conquest was not about 'ruling the world, but redeeming it,' that is 'to bring to light what they called the Dark Continent. ${ }^{11}$ Understanding the Victorian ideal of a global civilising mission is central to this topic as it was during the Victorian era that the British colonisation of Africa took place - and the subsequent establishment of the colonial state occurred.

\section{The Victorian mission - Maxim gun evangelism}

Historian Denis Judd shows a less idealistic side of Victorian era colonialism in Africa, by focusing on the activities of the multi-millionaire Cecil Rhodes. In 1877, Rhodes set about to establish a 'secret society, the aim of which was the extension of British rule

\footnotetext{
${ }^{10}$ Ferguson, p. 113

11 Ibid.
} 
throughout the world. ${ }^{12}$ Judd writes that Rhodes envisioned 'the establishment of a power so great as to hereafter render wars impossible and [therefore] promote the best interests of humanity. ${ }^{13}$ Judd articulates the view, shared by historian Martin Meredith in Diamonds, Gold and War, that Cecil Rhodes had an insatiable appetite for British domination of Africa - which was well reflected throughout his career. ${ }^{14}$ Ferguson weighs in on this idea also - by referencing Rhode's statement of intent when establishing the Rhode's Scholarship, 'Jesuits if attainable, and insert English Empire for Roman Catholic Religion. ${ }^{15}$ Considering that Rhodes was arguably one the most significant agents of empire in Africa during the colonisation period - one can observe a cleavage from the 'missionary' colonialism articulated above. These conflicting notions of Empire and its purpose are essential contributors to understanding the landscape of this subject. These philosophies inform the manner in which the British Government approached indigenous political leadership within the colonies - which is at fulcrum of this subject.

Staunchly critical of British Imperial operations in Africa is historian Richard Gott. This author writes on the subject from a passionately anti-colonial perspective in Britain's Empire: Resistance, Repression and Revolt. Gott argues that the British Empire was essentially an institution of violence, murder and the subsequent excise of domination of vanquished colonial peoples - an argument directly counter to the thesis of the

\footnotetext{
12 Judd, Dennis, Empire - The British Imperial Experience from 1765 to the Present, Scotland, 1996, p. 117

${ }^{13} \mathrm{lbid}$

${ }^{14}$ Meredith, Martin Diamonds Gold and War - The Making of South Africa, London, 2007, p. 311

${ }^{15}$ Ferguson, p. 221
} 
more apologetic historians who focus on the 'civilising mission' features of British colonial management. ${ }^{16}$

\section{A chaotic conglomerate}

John Darwin, another pre-eminent author on the British Empire, makes the assertion that:

'Far from being the 'designer empire' whose links and connections could be neatly traced from imperial centre to colonial periphery, it looked like a halffinished 'project of an Empire' (in Adam Smith's phrase) bound loosely together by a maze of wiring of uncertain age and untested strength. The questions that matter are why this was so, and how it was possible for this chaotic conglomerate to survive for so long into the age of global war after 1914? ${ }^{17}$

This inference by Darwin alludes to the idea the British Empire took very different forms in the multitude of contexts it was active. A significant moral disjunction that demonstrates this variance is that at the same time the Royal Navy was enforcing the abolition of the Atlantic slave trade, that same Navy was forcing open Chinese ports in order to further advance the interests of the Opium Trade. This study is therefore obliged to analyse the manner in which the British Empire manifested itself in the subject environments to gain a true understanding of how the Empire intersects with indigenous political leadership.

\section{In-built racism?}

Ambe J. Njoh delivers a sharpened focus, in Colonial Philosophies, Urban Space and Racial Segregation in British and French Colonial Africa. Njoh initiates his discussion by articulating the racial constructs prevalent in Britain and France in the late $19^{\text {th }}$ century, referencing the British equation of contemporary scientific findings on race as 'gospel truth.' Njoh argues that the British viewed themselves as Caucasians, therefore

\footnotetext{
${ }^{16}$ Drayton, Richard, 'Review of Richard Gott - Britain's Empire' in The Guardian, 2011, http://www.guardian.co.uk/books/2011/dec/07/britains-empire-richard-gott-review (Accessed 4th July 2012)

${ }^{17}$ Darwin John, in Stockwell, Sarah, The British Empire - Themes and Perspectives, Massachusetts, 2008, p. 3
} 
a 'race superior to all other races' - a premise which he asserts framed the colonial approach:

'It is important to note that Western racism and imperialism were heightened during the late $19^{\text {th }}$ and early $20^{\text {th }}$ centuries. This period coincided with the heyday of the European colonial project in Africa. As I show in this discussion, this negative development in race relations had far-reaching implications. ${ }^{18}$

Shortly after making this assertion Njoh moves to his main argument in the area of 'Racial Spatial Segregation in French, then subsequently, British Colonial Africa.' Njoh succinctly articulates that the British colonial operation of racial spatial segregation was inspired by the rationale of 'protecting the health of Europeans. ${ }^{19}$ Whether this was a delicate justification for institutional racism or not - the consequences of the pursuit of this policy were same - a racial pecking order emerged based on the way the British colonial authorities physically structured their communities. This literature is a crucial contributor this thesis - as this legacy feeds directly into the post-colonial leadership equation.

Piers Brendon articulates the savage realities of British activity in The Decline and Fall of the British Empire - 1781 - 1997. Brendon notes a heightened level of racism in Rhodesia, which could easily be attributed to the unique attitudes of the 'vociferous and powerful' white settler minority. He articulates this through the following anecdote;

'...the Chief Native Commissioner got so furious at the sight of a "raw native" wearing boots that he had the man flogged. As Milner himself acknowledged, the usage of the blacks was a scandal and "cannot be defended". 20

\footnotetext{
${ }^{18}$ Njoh, Ambe J., 'Colonial Philosophies, Urban Space and Racial Segregation in British and French Colonial Africa, in Journal of Black Studies, Volume 38, 2007, p. 581

${ }^{19}$ Njoh, p. 588

${ }^{20}$ Brendon, Piers, The Decline and Fall of the British Empire - 1781 - 1997, London, 2007, p. 569
} 


\section{Her Majesty's Colonial Service in Africa}

For an even sharper focus on British Imperial operations relevant to this subject, one can investigate the individual histories of the case-study colonial/post-colonial states. A useful starting point is A. H. M. Kirk-Greene's The Thin White Line: The Size of the British Colonial Service in Africa. This article quantitatively and qualitatively presents the historical realities of the British Colonial Service in Africa, with references to specific colonial states and regions. Kirk-Greene raises critically relevant points to this subject, such as the 'crash-programmes for Africanising the administrative cadres [that were] introduced into nearly every territory between 1957 and $1962 .^{.21}$ Kirk-Greene also effectively equips his readers to fully understand the role of 'the DistrictCommissioner' within British Africa - something equally crucial to the subject of African political leadership during decolonisation.

\section{Imperial policy spheres}

In Coping with the Contradictions: The Development of the Colonial State in Kenya, 1895 - 1914, John Lonsdale and Bruce Berman analyse the historical processes that formed the colonial political economy in Kenya. They argue Kenya is a worthy case study as it was subject to London's two major policy approaches to Africa; the 'West Coast' policy was based on the concept of a 'peasant political economy,' and a 'South African' policy with an emphasis on the settler political economy. Lonsdale and Berman make several conclusions in their paper. They assert that the political economy that was welded together in Kenya provided 'the internal dynamic of economic growth and political conflict over the next half century [post 1914]. ${ }^{22}$ An

\footnotetext{
${ }^{21}$ Kirk-Greene, A. H. M., 'The Thin White Line: The Size of the British Colonial Service in Africa, in African Affairs, Volume 79. No. 314, 1980, p. 30

${ }^{22}$ Lonsdale, John, and Berman, Bruce, 'Coping with the Contradictions: The Development of the Colonial State in Kenya, 1895-1914, in The Journal of African History, Volume 20, Number 4. 1979, p. 504
} 
important distinction that this article makes is the importance of 'the colonial state' as a major feature of decolonised political leadership equation.

Matthew Lange picks up this thread in British Colonial Legacies and Political Development. He asserts 'while most works analyse the long term effects of colonialism on economic development, several others consider democratisation, health and education. Regardless of the outcome variable, however, nearly all these scholars acknowledge the colonial state was the primary extension of foreign domination and investigate how its form and persistence over time have shaped future development.' $^{23}$ This is an acknowledgement that the colonial state is a fundamental unit of analysis when analysing the relationship between British imperial policy and independence political leadership outcomes. Building on this rationale, Lange identifies two broad categories of colonial state within the British Empire - Settlement colonies and extractive colonies. This distinction is important when analysing the impact of colonial policy.

There is a discernible theme emerging from the above texts on the nature of Britain's African policy during the colonial era. Authors reference distinctive differences in the British approach to African colonies. Historian Martin Meredith notes in The State of Africa - A History of Fifty Years of Independence; 'each of Britain's fourteen African territories was governed separately... Britain's West African Territories were the most advanced... In Britain's colonies in east and central Africa, political activity revolved around the demands of white settlers. ${ }^{24}$

\footnotetext{
${ }^{23}$ Lange, Matthew K, 'British Colonial Legacies and Political Development, in World Development, Volume 32, Number 6, 2004, p. 905

${ }^{24}$ Meredith, Martin, The State of Africa - A History of Fifty Years of Independence, London, 2006 p. 11
} 
It has already been noted that there was a distinction between a 'West African' and a 'Southern African' colonial policy. Matthew Lange adds more policy distinction by articulating the differences in approach to settlement colonies and extractive colonies. It is therefore critically important to attempt to locate the subjects of this study within these categories.

As noted earlier, the Kenya case straddles the policy categories. Lonsdale and Berman, assert that British imperial designs were, in fact, paralysed by the opposing demands of the 'West Coast,' and 'Southern African' policy in Kenya. ${ }^{25}$ This meant that the colonial state apparatus in Kenya was consistently drawn in opposite directions - one toward the primary focus on settler interests (mainly residing in the 'White Highlands'), and the other toward a peasant political economy with high emphasis on extraction. It is important to note that these policy paradigms, while useful for understanding the British approach, are not definitive. As referenced earlier, the views and approach of autonomous and powerful 'District Commissioners' acting under the authority of even more powerful Governors had as much to do with colonial state management as the policy frameworks mentioned above. This idea is also consistent throughout the literature.

'For God's sake don't worry headquarters' - the unique role of the Governor and District Commissioner

Niall Ferguson tells us that in Tanzania, or Tanganyika as it was referred to during the colonial era, the roll of the 'District Commissioner' or 'District Officer' was of amplified importance. ${ }^{26}$ The Tanganyikan colonial state is interesting in that the imperial policies of two different empires fed into its creation and construction. During the 'Scramble

\footnotetext{
${ }^{25}$ Lonsdale and Berman, p. 487

${ }^{26}$ Ferguson, Niall, p. 210
} 
for Africa' in the late $19^{\text {th }}$ century, Tanganyika was claimed by Germany, and held as a Germany colony until the First World War when Britain obtained a mandate to govern the East African state. This factor, coupled with the reality that Tanganyika offered it's colonial rulers no high value resources to extract, could be reasonably argued to have generated the ad-hoc nature in which Britain managed and developed this colony. Justin Willis argues in The Administration of Bonde, 1920 - 1960: A Study of the Implementation of Indirect Rule in Tanganyika that indirect rule was indeed the order of the day. ${ }^{27}$ Indirect rule meant a considerable amount of indigenous participation in their colonial governance, which contrasts directly with the Kenyan experience.

David Killingray argues that within the context of 'indirect rule' there were two basic pillars that colonial government in Africa rested upon. In The Maintenance of Law and Order in British Colonial Africa, Killingray argues that 'effective colonial government' relied upon; the maintenance of law and order to uphold the authority of the administration as one pillar, and the collection of adequate revenue with which to finance the running of the colony as the other. ${ }^{28}$ This creates a paradox for the Governors and District Commissioners, as on the one hand they were charged with operating in a minimalistic, 'indirect' manner, yet were also charged with preserving law and order and the collection of revenue. Killingray does, however, make the concession that conceptions of 'law and order' in the colonial context were somewhat different to that of the metropolitan milieu; 'In all colonies a dual system of laws was established, an alien law based on the system then pertaining in England, and

\footnotetext{
${ }^{27}$ Willis, Justin, 'The Administration of the Bonde - 1920 - 60: A Study of the Implementation of Indirect Rule in Tanganyika,' in African Affairs, Volume 92, Number 366, 1993

${ }^{28}$ Killingray, David, 'The Maintenance of Law and Order in British Colonial Africa,' in African Affairs, Volume 85, Number 340, 1986, p. 411
} 
customary law.' ${ }^{29}$ Killingray also argues that 'indirect rule was not concerned with the rule of law but with supporting the colonial structure.' ${ }^{30}$ The assertion that 'law and order meant different things to different people at different times,' is an important one as it highlights a much broader idea. The reality is that generalisations on the nature of British colonial rule in Africa are problematic. They are problematic because so much of British colonial activity was framed by the wildly variable interpretations the colonial agents had of British policy. This point does, however, serve to buttress the importance of the individual character of Governor or District Commissioner in understanding British colonial operations in Africa.

A discernible theme is therefore the amplified importance of the District Commissioner, and the paradoxical nature of that office. Understanding this is important to cultivating an understanding of how the British model of colonial governance in Africa impacted upon political leadership during the decolonisation phase. Another is the precarious balance these colonial agents were obliged to maintain between appeasing various interests including; preserving the colonial power structure, maintaining quasi-law and order, ensuring a favourable distribution of resources to settlers, keeping indigenous populations at peace with the Crown, collecting revenue and constantly trying to achieve 'more with less' in terms of political resources. The extent to which this historical reality feeds into the post-colonial leadership equation will be developed further in this work. Meredith remarked;

'A veteran native commissioner in Southern Rhodesia remembered being told that his duties as a District Officer were to: Get to know your district, and your

\footnotetext{
${ }^{29}$ Killingray, p. 413
}

30 lbid. 
people. Keep an eye on them, collect tax if possible, but for God's sake, don't worry headquarters. ${ }^{31}$

\section{The 'Winds of Change' - the British withdrawal from Africa}

The simple fact is that British global hegemony saw nearly a quarter of the world's population governed directly and indirectly by the political elites of Westminster. Ferguson notes in his introduction that the British Empire occupied roughly a similar proportion of the world's land surface - and had complete ascendancy on nearly all oceans around the globe, 'the British Empire was the biggest Empire ever, bar none. ${ }^{32}$ For this reason alone the raft of literature on the subject is overwhelming. To comprehensively analyse it all would significantly detract from the major theme of this this; which is leadership. This chapter therefore shifts focus to literature that focuses on the process of decolonisation in the subject environments - which established the context of leadership.

Martin Meredith's The State of Africa - A History of Fifty Years of Independence delivers and effective survey of the process of decolonisation in the subject colonies. In Meredith's 'Winds of Change' chapter, the historical narrative of this process in Africa is effectively laid out. Meredith notes the British desire for a 'long apprenticeship' for indigenous political leadership prior to the attainment of full self-rule; 'to give the colonies their independence,' said one senior Labour politician, Herbert Morrison, 'would be like giving a child a latch-key, a bank account and a shot gun.'33

The implementation of this 'long apprenticeship' was, however, severely challenged. In the post-World War Two era, there was open international disdain for the surviving

\footnotetext{
${ }^{31}$ Meredith, p. 6

${ }^{32}$ Ferguson, p. xi

${ }^{33}$ Meredith, p. 11
} 
Empire's and their trappings. This disdain communicated on the international diplomatic stage by representatives of the world's two new super powers, the United States of America and the Union of Soviet Socialist Republics. The implementation of the 'long apprenticeship' for African self-government was further challenged by the 'game changing' diplomatic defeat of Britain and France by Gamal Abdul Nasser in Egypt, regarding the Suez Canal in 1956. In Meredith's chapter Revolt on the Nile, he references the substantial shift in the British policy for the African colonies, especially with regard to the process and timeline for African self-governance. ${ }^{34}$

In Britain and Decolonisation, John Darwin asserts that because 'Britain's legendary financial resources were devastated by the costs of war and the ravages of depression... the subject peoples of empire became more recalcitrant and in some places their resistance was more effective. ${ }^{35}$ In Meredith's aforementioned The State of Africa - A History of Fifty Years of Independence, there is a catalogue of examples of the extent to which British 'Imperial Fatigue' dictated the timeline for independence especially when local 'recalcitrance' was involved. A survey of the literature therefore allows the researcher to infer that despite the noble ambitions of 'long apprenticeships' for the self-government, the reality was that with a few notable exceptions, the British Empire was quick to retreat in the twin faces of nationalist movements and international pressure. The realities of how imperial fatigue dictated the decolonisation process in Africa are of critical importance to the subject of political leadership after the British in Africa.

\footnotetext{
${ }^{34}$ Meredith, pp. 30-44

${ }^{35}$ Darwin, John, Britain and Decolonisation - The Retreat from Empire and the Post-War World, 1988, p. 
It can therefore be contended that an important force in the process of decolonisation was how financially devastated Britain was, and the extent to which this framed policy and decision making regarding the African colonies. The substantial depletion of imperial resources, coupled with the humiliation of the Suez Affair in 1956, meant that Britain's lust for any further African imperial development was gutted. The final nail in the coffin of British interests in Africa was arguably the 'Mau Mau' rebellion in Kenya.

\section{Britain, the Mau Mau, and decolonisation in Kenya}

'No other revolt against British rule in Africa gained such notoriety as the Mau Mau rebellion in Kenya. ${ }^{36}$

Historian Piers Brendon argues that the seeds of the 'Mau Mau' rebellion had been sown during the decades before as a consequence of the British appropriation of land. Brendon asserts that to the Kikuyu people of Kenya 'land was life.'37 The Kenyan discontent emerged from the radically disproportionate appropriation of land between the settlers, numbering around three thousand and over a million Kikuyu - the largest ethnic group in Kenya. As mentioned above, Kenya awkwardly straddles both major colonial policy approaches that the British had for Africa. The settler population was just big enough to exact demands on the colonial state, yet not so big that it could be self-sufficient in subjugating the indigenous peoples (as in Rhodesia or South Africa for example). This meant the colonial state was torn between appeasing two highly distinct and opposing sets of interests, as well as the need to maintain 'law and order' in the East African colony. The British attempted to mitigate this by pursuing 'multiracialism';

'...because of the presence of vociferous and powerful white minorities, a different timetable [for independence] was envisaged. Britain's aim in post-war years was to develop what it called 'multiracial' societies'... a 'partnership'

\footnotetext{
${ }^{36}$ Meredith, p. 85

${ }^{37}$ Brendon, Piers, The Decline and Fall of the British Empire - 1781 - 1997, London, 2007, p. 545
} 
between white and black albeit under white leadership.' White leadership was regarded as indispensable for economic development. ${ }^{38}$

This dichotomy was unsustainable considering the shear numerical discrepancy between the races.

With the speeding up of land appropriations from Kenya's indigenous peoples to make way for British ex-servicemen from World War One, and the subsequent expulsions of 'African squatters' from 'White' land - tensions soon began to boil over into physical confrontation and conflict. The drift toward this conflict, Brendon argues, was amplified by the settlers "visceral determination to control the "raw savages" who could turn Kenya into a "second Liberia". ${ }^{39}$ This settler activity, and the permission of it by the colonial authorities, was a key contextual force in the subsequent independence leadership environment. Brendon notes that this exercise in control and subjugation was achieved through the establishment of 'district councils' - which were soon stacked with settlers, or seconded administrators sympathetic to the settler cause. This meant that 'the Nairobi government, which had previously maintained a façade of impartiality, became much more closely identified with the interests of the settlers. ${ }^{40}$ This established the pretext for civil conflict, as Kenyan nationalists became aware that they were not going to achieve 'uhuru' (freedom) through Kenya's civic institutions. Brendon's account then moves swiftly into articulating his historical assessment of the drift to uprising - and the eventual Mau Mau uprising itself.

This literature is fundamental to this study as it grows an understanding of the environmental dynamics that surrounded the first of the leadership cases on which this study will focus. The historical forces that Brendon articulates above are what

\footnotetext{
${ }^{38}$ Meredith, p. 78

${ }^{39}$ Ibid, p. 546

${ }^{40}$ Ibid, p. 78
} 
framed Jomo Kenyatta's political milieu. D. George Boyce is another imperial historian who assists the researcher in conceptualising how British activity worked to create the political world in Kenya - of which Kenyatta would soon rise to the apex. In Decolonisation and the British Empire, 1775 - 1997 D. George Boyce approaches decolonisation and the 'Mau Mau' from a more holistic perspective. He focuses on an awkward disjunction that colonial policy makers had to deal with during the civil unrest of 1950's Kenya. Boyce writes that while colonial authorities were obliged to try and restore some semblance of law and order in Kenya, they were incredibly careful not to alienate the 'black political elites.' This was because, Boyce argues, the British Government still maintained a policy of gradual enfranchisement then eventual handover of political affairs to the African majority, despite the differing goals of the settlers. $^{41}$

\section{In Search of Ujaama - The British retreat from Tanganyika/Tanzania}

Scholarship on the nature of British operations in Tanzania, or Tanganyika as it was formerly known, is more limited than that focusing on Kenya. The colony of Tanganyika was only acquired by Britain as a League of Nations 'Mandate,' post-World War One. After a period of 'caretaker governance,' one can discern from the writings of John Darwin, that British policy makers envisioned that the colony of Tanganyika would be amalgamated into a 'federal East Africa. ${ }^{42}$ Darwin interestingly notes;

'settler influence in Kenya predominated, and Kenya was still a 'white-man's country.' Uganda on the other hand, had only a handful of European permanent residents... [and] was plainly a 'black man's country.' Tanganyika, formally a trusteeship territory, stood halfway between the two. ${ }^{43}$

\footnotetext{
${ }^{41}$ Boyce, D. George, Decolonisation and the British Empire, 1775 - 1997, London, 1999, pp. 198 - 204

${ }^{42}$ Darwin, John, Britain and Decolonisation : The Retreat from Empire in the Post-War World, 1988, $\mathrm{p}$. 189

${ }^{43}$ Ibid, pp. 189-190
} 
For British policy makers, this generated the disjunction that is referenced above between pursuing the settler policy approach, or the alternative, peasant based 'West African approach' in Tanganyika. Darwin argues that the British pursuit of a federal scheme for East Africa - therefore including Tanganyika, could solve some of the political management problems London policy makers were facing. The establishment of a federation, it was hoped, would create a political environment where settlers and the indigenous population would work more cooperatively. Establishing such a federation was also in line with the general British approach referenced above, of 'indirect rule.' Darwin notes that the federalist intentions of the British had an unseen side-effect of fermenting Tanganyikan nationalism. ${ }^{44}$ Out of this nationalist movement springs this thesis' second leadership subject, Julius Nyerere.

\section{Conclusions on literature relevant to British imperial operations in the subject colonies.}

There are several discernible themes from the literature reviewed above - on the nature of British imperial operations in the subject colonies. One of the most important to this study is that of 'indirect rule' and the British policy culture of minimalistic governance. This extent to which this approach framed the independence political experience remains to be exposed throughout this thesis. John Cartwright argues in Political Leadership in Africa, that 'a wide range of political, social and economic forces encouraged the new rulers to eliminate rivals and to close off channels for direct challenges to their position' - thus augmenting the drift toward some of the more spectacular leadership failures in modern history. A major force in Cartwright's 'wide range' was the British appetite for a minimalistic government apparatus. This is a recurring theme in all of the literature surveyed above. Within this

\footnotetext{
${ }^{44}$ Darwin, pp. $189-190$
} 
minimalistic apparatus, the role of the District Commissioner was so empowered that they were essentially given absolute power - within their dominions. This essentially meant the 'colonial state' was in practice a collection of miniature fiefdoms led by the District Commissioner, under the loose over-lordship of a governor, who was subject to an even more loose over-lordship from London. This subsequently meant, as referenced above, that the manifestations of Empire in the subject colonies vary as widely as the personalities of the District Commissioners and Governors.

\section{Literature on Political Leadership Theory}

Having surveyed literature that explains the nature of the British contribution to the political leadership equation that this project seeks to expose, if not solve, the next critical input to the equation is theories that seek to explain the behaviour of the actors themselves. This leads this scholar to focus on applicable theories for actor behaviour in relation to the interplay between the leader and leadership context. Frederick Greenstein's theoretical approach to the situational relationship and the action dispensability delivers quality insight into the context of this thesis. James McGregor Burns' prism for analysing leadership is also a significant contributor to this study.

\section{$\underline{\text { James McGregor Burns and the transformational leader }}$}

James McGregor Burns' approach to political leadership rests on the theoretical pillar that a great leader is transformational in their interactions and relationships with followers. Burns asserts 'transforming leadership, while more complex, is more potent. ${ }^{, 45}$ Burns' conceptions of transformational leadership centre on an assertion that successful leadership occurs when a leader raises the moral deportment of the

\footnotetext{
${ }^{45}$ Burns, James McGregor, Leadership, New York, 1979, p. 4
} 
followership - through the mobilisation of shared ideas, values and myths. Burns' argues that the study of leadership has been hampered by a 'bifurcation between the literature on leadership and the literature on followership,' and therefore seeks to bring the two literary traditions together, seeing the roles of leader and follower 'united conceptually. ${ }^{46}$ As a consequence of this conceptual unification - Burns arrives at the position that 'transforming leadership is a relationship of mutual stimulation and elevation that converts followers into leaders and may convert leaders into moral agents. $^{, 47}$

Burns raises a clarion warning to interested scholars that an analysis of political power remains perennially unbalanced until that analysis acknowledges the forces that limit power - and thus force leadership to take place as a dynamic interaction. This warning is vital to this thesis, as in many of the cases studied leaders appear to be endowed with absolute power. Heeding this warning - this thesis looks to engage with the leadership-followership interaction as it took place in Kenya, and Tanzania.

Continuing this theoretical trajectory, Burns makes clear distinctions between leaders and 'power wielders. ${ }^{48}$ 'To control things - tools, mineral resources, money, energy is an act of power, not leadership, for things have no motives. Power wielders may treat people as things. Leaders may not. ${ }^{49}$ This demonstrates how Burns' thesis is grounded in the idea that 'true leadership' is a relationship based interaction. 'I define leadership as leaders inducing followers to act for certain goals that represent the values and the motivations - the wants and needs, the aspirations and expectations of

\footnotetext{
${ }^{46}$ Burns p. 3

${ }^{47}$ Ibid p. 4

${ }^{48}$ Ibid, p. 18

${ }^{49}$ Ibid, p. 18
} 
both leaders and followers. ${ }^{50}$ The application of these relationship based conceptions of leadership to the case studies of this thesis will be a challenging and complex process. Understanding the unique tapestry of inter-relationships, however, in the post-colonial African contexts will yield critical elements of the leadership equation.

Burns' asserts that 'the essential strategy of leadership in mobilising power is to recognise the array of motives and goals in potential followers, to appeal to those motives by words and action, and to strengthen those motives and goals in order to increase the power of leadership, thereby changing the environment within which both followers and leaders act. ${ }^{51} \mathrm{~A}$ leader then subsequently undertakes the 'fundamental act' of raising the followership's awareness of what they are feeling - to the extent that they meaningfully define their values and 'can be moved in purposeful action. $^{52}$

Burns uses different classifications of 'followers,' varying from the totally activated and engaged to the 'apathetics, the anomics, the alienated and excluded... latent followers, unrealised, dormant. ${ }^{53}$ Burns' emphasis on classifying followers or followership will be implemented in this thesis. The unique nature of the 'followership,' in each of the given contexts, is a critical force in conceptualising post-colonial political leadership in Africa. Burns acknowledges that followers must be 'activated' by leaders - thus beginning the leadership interaction. ${ }^{54}$ 'The activated followers are generally even more diverse than the activators (leaders); indeed, it is the contrary assumption - that one follower is necessarily like another... that has led to so much attempted activation

\footnotetext{
${ }^{50}$ Burns, p. 19

${ }^{51}$ Ibid, p. 40

52 lbid, p. 44

${ }^{53}$ Ibid, pp. 132 - 135

54 Ibid, p. 130
} 
that finds either no response or unanticipated responses. ${ }^{, 55}$ Burns' method for the classification of followers uses analysis of their 'psychological, social and political settings. ${ }^{56}$ He refers to a 'five nation study' ${ }^{57}$ undertaken by Norman Nie, Bingham Powell and Kenneth Prewitt, in which five attitude sets were identified as relevant to the classification of followership. These were; a sense of citizen duty, basic information about politics, a perceived stake in political outcomes, a sense of political efficacy and attentiveness to political matters. ${ }^{58}$

Burns' theoretical approach to leadership as a relationship, whereby leader and follower dynamically interplay by either transformation or transaction - requires some assumptions to be accepted. Burns' identifies that one of the most critical of these is the existence of universal and uniform human 'needs. ${ }^{.59}$ This is to say that across culture, gender, ethnicity, resource endowment, physiological disposition, and myriad more divides, there are common motivations and purposes. These common motivations and purposes are fundamental to the theory as they provide grounding for understanding followership, as Burns defines it:

'If we define leadership as not merely a property or activity of leaders but as a relationship between leaders and a multitude of followers of many types, if we see leaders as interacting with followers in a great merging of motivations and purposes of both, and if in turn we find that many of these motivations and purposes are common to vast numbers of human kind in many cultures, then we could expect to identify patterns of leadership behaviour permitting plausible generalisations about the ways in which leaders generally behave. ${ }^{60}$

This thesis rests heavily on Burns' consideration here. Without this justification, the research that supports this thesis would be obliged to extend to undertaking extensive

\footnotetext{
${ }^{55}$ Burns, pp. $130-131$

56 Ibid.

${ }^{57}$ Ibid, p. 131 (Germany, Italy, Mexico, the United States, and the United Kingdom)

${ }^{58}$ Ibid.

59 Ibid, p. 30

${ }^{60}$ Ibid, p. 30
} 
political-psychological surveys of surviving citizens (or followers) from Tanzania and Kenya. Burns asserts, that '[research] in the field of moral development [has] uncovered remarkable uniformities in hierarchies of moral reasoning across a number of cultures. ${ }^{61}$ Burns however notes that identification of leadership patterns does not depend of finding absolutely universal motives and values. Universal patterns simply assume strong probabilities that most leaders in interacting with followers will behave in similar ways most of the time. ${ }^{62}$ To buttress this consideration, this thesis will also employ Abraham Maslow's Hierarchy of Needs - a theoretical framework which will be reviewed subsequently.

On understanding the leader's psychological predisposition, Burns' makes another important warning to the interested scholar. Burns articulates concerns about the validity of 'early life' analysis of political leaders. 'Memories of the early years are woefully, even perversely limited and distorted. ${ }^{, 63}$ This is not to say analysis of early life is not important, only that it is the task of 'the trained analyst to sift through [the] dross. ${ }^{64}$ He nevertheless asserts that 'psychobiography... can be an indispensable tool in analysing the shaping influences on leadership. Like all tools, it must be used cautiously, and adjusted to the task at hand. ${ }^{65}$ This warning is also heeded by this thesis- with regard to the examination of the early lives of the chosen subjects. Burns engages in great depth, with the psychological processes involved with this analysis.

Burns' ultimate conception of a political leader is the 'transformational' leader who mobilises their political resources to engage with the morality of the followership in

\footnotetext{
${ }^{61}$ Burns, p. 30

62 Ibid.

${ }^{63}$ Ibid, p. 51

64 Ibid.

65 lbid, p. 53
} 
such a way that it is elevated beyond basic human want and need - into the higher purposes. Burns also acknowledges the existence and importance of 'transactional leadership.' This style of leadership is less focused on raising the moral deportment of the followership through a relationship of mutual understanding, and rather gravitates around bargaining and exchange between leader and follower as the critical dynamic of the leadership interaction. The 'transactional' theory of leadership interaction holds that the relationship revolves around the exchanging of gratifications in the political marketplace. ${ }^{66}$ The transactional approach holds that leader and follower are 'bargainers seeking to maximise their political and psychic profits. ${ }^{67}$ Burns' believes that this leadership approach must lead to 'short lived relationships,' because the participants in the exchange cannot continue to exchange identical items, 'both must move on to new types and levels of gratifications. ${ }^{, 68}$ If the researcher extrapolates this assertion onto the post-colonial African leadership context, a wealth of insight becomes available into possible the break down in leader-follower relations.

Burns uses the example of Mao Zedong as one of his archetypical 'transformational' leaders. He argues that Mao had an 'uncanny insight into the... motivations of the Chinese people. ${ }^{69}$ Wielding this insight, Mao was able to tap into the motives of his followership - 'he opened the floodgates to an outpouring of supressed resentments and grievances; he channelled the protest to serve his own ends and, to varying degrees, the ends of his followers. ${ }^{, 70}$ Burns asserts that Mao's leadership delivered such epic success as consequence of his ability to be 'far more attuned' to the needs of

\footnotetext{
${ }^{66}$ Burns, p. 258

${ }^{67}$ Ibid.

${ }^{68} \mathrm{Ibid}$

${ }^{69}$ Ibid, p. 404

${ }^{70}$ Ibid.
} 
China's rural population - when compared with his rivals. ${ }^{71}$ Mao Zedong was also Burns' keystone example of a 'revolutionary leader' - a sub-category of transformation leadership which he brands as 'passionate, dedicated, single-minded, ruthless, selfassured, courageous, tireless, usually humourless, often cruel. ${ }^{72}$ Burns also asserts that it arises from a 'chiliastic political theology'; however it remains flexible in regard to the practical application of this theology. ${ }^{73}$ Burns also argues it centres on conflict and is sourced from the leader's ability to ignite the passions of the followership that arise from their wants and needs. ${ }^{74}$

Contrasting with revolutionary leadership is reform leadership. Burns' employs a H.M. Kallen quote to articulate this contrast: "the reformer seeks modifications harmonious with existing trends and consistent with prevailing principles and movements. The revolutionist seeks redirections, arrest or reversal of movements and mutation of principles... It is this insistent exclusive particularism which distinguished the reformer from the revolutionary as a psychological type. ${ }^{, 75}$ Burns argues that the efforts of reform leadership can often be frustrated and compromised as a consequence of the leader accepting the social and political structures within which they act - and are therefore 'inhibited by the tenacious inertia of the existing institutions. ${ }^{76}$ There is considerable potential for the application of these considerations and classifications to the cases used in this thesis. Burns asserts revolutionary leadership 'requires a prophet

\footnotetext{
${ }^{71}$ Burns, p. 234

72 Ibid, p. 239

${ }^{73}$ Ibid.

74 Ibid.

${ }^{75}$ Ibid, p. 170

${ }^{76}$ Ibid, p. 200
} 
but it needs institutional support and collective leadership to survive. ${ }^{, 77}$ This idea lies at the heart of the Tanzanian case of Julius Nyerere.

Burns also advances the idea of 'heroic leadership' as another brand of leadership under the transformational umbrella. ${ }^{78}$ He asserts 'Heroic leadership plays a vital role in transitional or developing societies, where even the more idolatrous form of heroic leadership may meet the special needs of both leaders and followers. ${ }^{, 79}$ This assertion and consideration is also crucial to this thesis. The sub-Saharan post-colonial political and social environment provided incredibly fertile ground for the emergence of Burns' brand of heroic leadership. 'The idolatrous form of heroic leadership can serve, in Robert C. Tucker's words, as "essentially a fulcrum of the transition from colonial-ruled traditional society to politically independent modern society" , ${ }^{80}$

Burns' approach to political leadership is invaluable for developing an understanding of post-colonial political leadership in Tanzania and Kenya. Following Burns' lead, this thesis will continuously seek to understand the needs and motives of the 'followership' in the given contexts. Burns' makes absolutely clear - the necessity of understanding the leadership-followership interaction and its dynamics as the crucial element of any leadership equation. Especially noteworthy is Burns' emphasis on understanding the level of 'activation' of the followership. For example Burns' statement 'it is abundantly clear that the lower class cannot and does not feel as much sense of power in, and responsibility for the institutions of government and economy as does the middle

\footnotetext{
${ }^{77}$ Burns, p. 238

78 Ibid, p. 71

${ }^{79}$ Ibid, p. 246

80 Ibid, p. 246
} 
class $^{81}$ - is highly applicable to thesis for myriad reasons that will be articulated throughout this work.

\section{Abraham Maslow's Hierarchy of Needs}

Abraham Maslow's psychological theory of a 'Hierarchy of Needs' - is critical to this thesis with respect to understanding the 'followership,' in the given contexts. Maslow's hierarchy of needs is based on the preposition that 'human needs arrange themselves in hierarchies of pre-potency... the appearance of one need usually rests on the prior satisfaction of another... no need or drive can be treated as if it were isolated or discrete; every drive is related to the state of satisfaction or dissatisfaction of other drives. ${ }^{82}$ Maslow uses five strata of need to make up his hierarchy. The first and most basic level of needs are what Maslow classifies as 'physiological needs' these are the basic survival needs of food, fluid, exercise, excretion, and the list of other essential requirements the human being physiologically needs to survive. Maslow asserts that these needs are 'the most pre-potent of all needs. ${ }^{83}$

When these needs are satisfied, the individual is subject to the next level of needs in Maslow's hierarchy of pre-potency - the 'safety needs. ${ }^{84}$ 'If the physiological needs are relatively well gratified, there then emerged a new set of needs, which we categorise roughly as safety needs. ${ }^{, 85}$ In the same way as the physiological needs, safety needs can serve as the 'exclusive organisers' of the behaviour of an individual. ${ }^{86}$ According to Maslow, an individual's safety needs are, broadly speaking, satisfied when for example, they are 'safe enough from wild animals, extremes of temperature, criminals,

\footnotetext{
${ }^{81}$ Burns, p. 77

82 Maslow, Abraham, 'A Theory of Human Motivation,' in Psychological Review, Volume 50, 1943, p. 370

${ }^{83}$ Ibid, p. 373

${ }^{84}$ Ibid, p. 376

${ }^{85}$ lbid, p 376

${ }^{86}$ Ibid, p. 76
} 
assault and murder, [or] tyranny... therefore in a very real sense he no longer has any safety needs as active motivators. ${ }^{87}$ With the physiological and safety needs accounted for, the individual can then be subject to Maslow's next tier of needs - the needs of love, affection and belonging. ${ }^{88}$ These needs are fairly self-explanatory - and not hugely relevant to this thesis. Essentially, these broadly refer to a hunger for the gratification and affection that comes from familial and other forms of human relationships.

As the physiological, safety, and love/affection needs are all satisfied, Maslow asserts that the individual is then subject to the needs of 'esteem.' These needs arise out of an individual's desire for 'a firmly based, (usually) high evaluation of themselves, for selfrespect, or self-esteem, and for the esteem of others. ${ }^{89}$ Maslow asserts that when the esteem needs are satisfied, the individual experiences feelings of confidence, worth, strength and adequacy. Maslow also notes that when an individual's esteem needs are thwarted, it can lead to feelings of 'inferiority, weakness and helplessness.' 90 Nevertheless, supposing an individual's needs for esteem are met, Maslow asserts that the individual is then subject to what he classifies as the highest form of need - selfactualisation. Self-actualisation refers to the fulfilment of potential and/or purpose: 'This tendency might be phrased as the desire to become more and more what one is, to become everything that one is capable of becoming. ${ }^{91}$

Maslow makes the important assertion that one could assume from his theoretical discussion that an individual moves in a 'step-wise' fashion through the needs listed

\footnotetext{
${ }^{87}$ Maslow, p. 379

${ }^{88}$ Ibid, p. 381

${ }^{89} \mathrm{lbid}$

${ }^{90}$ Ibid, p. 382

${ }^{91}$ Ibid.
} 
above. ${ }^{92} \mathrm{He}$ asserts that this is not the case and that there are 'degrees of relative satisfaction" ${ }^{93}$; "If one need is satisfied then the other emerges". This statement might give the false impression that a need must be satisfied 100 per cent before the next need emerges. ${ }^{94}$ Maslow clarifies that most normal members of developed society live partially satisfied in all of their needs and partially unsatisfied in all of their needs. ${ }^{95}$

Maslow's hierarchy of needs is a very useful companion to Burns' theoretical approach covered above. Maslow's hierarchy fits very neatly into the leadership equation that frames this thesis. This is because the hierarchy enables the scholar to better understand the dynamics of the followership in context - their responses to leadership and vice-versa. Maslow notes that when an individual's prior satisfaction of a need is threatened - an emergency response is triggered by the individual, or a defence mechanism that exists for the protection of that particular need's satisfaction. This acknowledgement helps to hypothesise about some of the 'follower/citizenry' responses to the new post-colonial political leadership in Africa, especially by the indigenous elites who had fared well under British administration. As asserted by Burns, and noted above, understanding the dynamic motivations of followership is a crucial ingredient to developing an effective comprehension of political leadership in any context. Maslow's hierarchy buttresses Burns' claim that similar 'motivations and purposes are common to vast numbers of human kind in many cultures' and therefore enables the scholar to 'identify patterns of leadership behaviour permitting plausible generalisations about the ways in which leaders generally behave. ${ }^{96}$

\footnotetext{
92 Maslow, p. 388

93 Ibid.

${ }^{94}$ Ibid.

${ }^{95}$ Ibid.

${ }^{96}$ Burns, p. 30
} 


\section{Frederick Greenstein on Personality and Politics}

Burns and Maslow make a substantial theoretical contribution to this thesis - they create a framework for understanding the leader-follower interaction and thus a crucial dimension the leadership equation. Frederick Greenstein's analysis, in contrast focuses on the personality of the leader - and how this personality interplays with the leadership context or milieu (of which the followership makes up a significant though not exclusive part). In searching for a definition of personality, Greenstein asserts that it 'accounts for the regularities in an individual's behaviour as he responds to diverse stimuli. ${ }^{\prime 97}$ On behaviour, Greenstein asserts that it 'is a function of the actor's psychological predispositions and the environmental influences that impinge upon him. ${ }^{98}$ Even applying these definitions alone, to the African post-colonial political leadership context, important insights emerge. Questions such as how the various leaders were psychologically predisposed to deal with the very unique and intense external stimuli which framed their leadership situations - are at the centre of this inquiry. On external stimuli or situational stimuli, Greenstein notes that the actor's perception of the environment is an equally important variable as the environment or external stimuli itself. ${ }^{99}$

Greenstein also proposes that actions of political leaders should be envisaged on a continuum - 'ranging from those that are indispensable for outcomes that concern us through to those that are utterly dispensable. ${ }^{100}$ He asserts that where actions are located along this continuum can often be explained and justified by '(1) the degree to which the actions take place in an environment which admits of restructuring, (2) the

\footnotetext{
${ }^{97}$ Greenstein, Frederick ,Personality and Politics - Problems of Evidence, Inference and Conceptualisation, Chicago, 1969, p. 3

98 Ibid, p. 26

99 Ibid, p. 28

100 Ibid, p. 41
} 
location of the actor in the environment, and (3) the actors peculiar strengths and weaknesses. ${ }^{101}$ To illustrate these points, Greenstein employs an analogy from the pool room:

'In the game of pocket billiards, the aim of the player is to clear as many balls as possible from the table. The initial distribution of balls parallels my first observation about the manipulability of the environment. With some arrays a good many shots are possible; perhaps the table can even be cleared. With other arrays no successful shots are likely. The analogy to point two - the strategic location of the actor - is, of course, the location of the cue ball. As a final point, we may note the political actor's peculiar strengths and weaknesses. In the poolroom, these are paralleled by the player's skill or lack of skill. Skill is of the upmost importance, since the greater the actor's skill, the less his initial need for a favourable position or manipulable environment, and the greater the likelihood that he himself will contribute to making his subsequent position favourable and his environment manipulable. By the same token, a singularly inept politician may reduce the manipulability of his environment. ${ }^{102}$

This method of analysis proposed by Greenstein is of substantial relevance to this thesis. This is because the situational 'array' of Greenstein's billiard balls in the context of African decolonisation was so unique, and provided a remarkable challenge to the first leaders 'peculiar strengths and weaknesses.' When this approach is synthesised with the Burns and Maslow approaches covered above, the researcher really begins to understand the incredible dynamics of the post-colonial political leadership equation in ex-British Africa. The synthesis of this theoretical literature creates a series of questions about the post-colonial leadership experience which this thesis intends to answer. They are;

1. How strategically well placed were Jomo Kenyatta and Julius Nyerere to affect meaningful political change in their selected environments? (Greenstein)

2. How and to what extent did the psychological predispositions of the 'followership' in the selected cases (at different times and phases) enable or

${ }^{101}$ Greenstein, p. 42

102 Ibid, p. 45 
disable the leader's ability lead, and therefore affect historical outcomes? (Burns, Maslow)

3. What were the other forces that made up the 'situational array' in the selected cases, and how stable or unstable were they? (Greenstein)

4. Did the subject leaders possess the peculiar strengths required to engage the 'followership' and direct them toward a meaningful goal and thus manipulate the situational array - or was the situational array too oppressive for even the most skilful political actor to manipulate? (Greenstein, Burns, Maslow)

5. To what extent was the British method of colonial development and management responsible for the answers to the above questions?

Some indicative yet rudimentary answers are provided by John Cartwright in Political Leadership in Africa.

\section{John Cartwright - Political Leadership in Africa}

On strategic placement Cartwright asserts that the independence leader's location within the political context was paradoxical. He argues that the fluid nature of the transitional political systems in post-colonial Africa gave leaders scope to take their countries in a variety of directions. ${ }^{103}$ 'Their fragile institutions and weak civic culture have paradoxically both limited what a leader can achieve while at the same time enhancing his power. ${ }^{104}$ Cartwright asserts that a collection of the forces associated with this created an institutional or 'situational array' which generated what Cartwright calls - 'pressures toward autocracy. ${ }^{105}$ In Political Leadership in Africa he asserts that these forces had political, social and economic origins. In further reference

${ }^{103}$ Cartwright, p. 2

104 Ibid.

105 lbid, p. 53 
to strategic placement, Cartwright argues that the political systems that the British bequeathed the new independent states envisaged electoral competition, yet 'also featured a concentration of power in the hands of a single executive,' vested in a parliamentary Prime Minister. ${ }^{106}$ As ideological traditions were generally quite limited in these new states - the emergence of electoral competition between non-tribal based political parties was slow to emerge. When this factor was combined with a Westminster style executive endowed with considerable powers - a Prime-minister's office emerged that was unduly powerful in its relationship to other countervailing power centres. This located the new leaders in a political position that was in some ways very powerful and poised to deeply affect historical outcomes.

Cartwright argues that the inherited institutions also weakened the leaders' strategic positioning within their political context - hence the paradox referenced earlier; 'Not only did the small size (and often inexperience) of the civil service restrict its ability to generate and process the information a ruler would need in order to canvass effectively a range of policy options, but the sheer mass of day-to-day demands meant that few leaders or their lieutenants had the time to take a long range look at where they were going. ${ }^{107}$ This problem with further exacerbated by the reality that the structures necessary for implementing new policies - a party to educate public opinion and an administration capable of working out the technical problems - scarcely existed. ${ }^{108}$ These forces created a situation where in some areas leaders' could act with unbridled power to profoundly affect the lives of their citizenry - yet in other areas the same leaders were mortally hamstrung to take their followers in any

${ }^{106}$ Cartwright, p. 54

107 Ibid.

108 Ibid, p. 58 
direction at all. Cartwright concludes on this point that the strategy choices that leaders could make were bounded by the following considerations;

1. 'Politically, most leaders had not fashioned reliable instruments for controlling or guiding their people.'

2. 'Economically they were still in a circular trap of "underdevelopment", which they had to escape in order to provide material payoffs needed to maintain their own support as well as to improve their peoples' lives.'

3. 'Socially, they had to ensure an equitable distribution of such benefits as they could extract, to avoid the danger of their state being shattered by ethnic conflict. $^{109}$

Cartwright illuminates important features of 'psychological predispositions' of the 'followership.' He argues that one of the most harmful colonial legacies to the fortunes of the post-independence governance was a 'legacy of deep suspicion and distrust of "the government". 'Despite the overlay of representative institutions which was attached to each colony during the period of decolonisation, the reality of government for most Africans was authoritarian power wielded in an unpredictable and capricious manner' by the former colonial masters. ${ }^{110}$ This meant that any independence leader seeking to use the machinery of government to affect lasting change in their new country had to first overcome deep and widely held suspicion of central government itself from within the public domain.

\section{Conclusions on literature on the relevant political leadership theory}

A collection of theorists and authors have been used above to form the prism or equation through which the subsequent analysis of the case leaders will be

\footnotetext{
${ }^{109}$ Cartwright, p. 58

${ }^{110}$ Ibid, p 13
} 
undertaken. James McGregor Burns' contribution to this equation is the most prominent. Burns' provides considerable grounding for the analysis in focusing on the dynamic interactions that occur between the political leaders and their followers. It is through analysing the cases with Burns' theoretical guidance that the researcher can understand how the leadership-followership interaction framed so much of the fortunes of the subject leaders' experience. Abraham Maslow's contribution lies in the extent to which it buttresses Burns' considerations regarding understanding the psychological pre-dispositions of the followership. Maslow's 'hierarchy of needs' is especially useful for growing the understanding of the motives of the followership these motives being a critically important contributor to the leader-follower relationship. Frederick Greenstein expands the terms of the interaction beyond the followership and considers the way the leader interacts with their institutional or situational surroundings - their milieu, as a further critical element of understanding the leadership equation. Greenstein also makes the contribution that the researcher must look to the leaders' peculiar strengths and weaknesses, in terms of personality, as key inputs to the equation as well. Greenstein also directs the researcher to examine the extent to which the leadership environment is fluid or undergoing 'restructuring' as an indicator of the likelihood of that leader having a significant or insignificant impact upon historical outcomes. With these factors considered, Greenstein also illuminates the leader's strategic location within their historical context, or environment, as another indicator of the leader's potential to affect a lasting impact. 


\section{Chapter Two - Jomo Kenyatta}

In 1973, African historian Guy Arnold wrote that Jomo Kenyatta was one of the outstanding African leaders of his generation. He asserts that because of the length of his tenure, Kenyatta was involved in almost every phase of political activity in the new and independent Kenya. Similarly to Arnold, historian Dennis Wepmen asserts that Kenyatta's life and career had seen the British 'in and out' of Kenya, and that when he died on the $22^{\text {nd }}$ of August 1978 Kenyan's understood they had lost a leader who would leave an unmistakable imprint on their nations future. ${ }^{111}$

Jomo Kenyatta was born into a political environment of 'restructuring.' As he passed through adolescence the restructuring intensified until the political environment was so fluid that radical transformation was inevitable (circa 1950s-60s). This coincided with the awakening of Kenyatta's political consciousness and leadership 'calling' - as well as the political awakening and activation of many of his countrymen. This awakening created a dynamic and engaged 'followership' - an integral element of Burns' theoretical approach referenced in the previous chapter. This generated a potent political leadership context - one that Kenyatta proved effective in manipulating, to the extent that he is remembered as one of the great African liberators. $^{112}$

When Kenyatta was on trial in 1952 for the suspected organisation of the Mau Mau colonial resistance movement, he stated, 'I do not know when I was born - what date, what month, or what year - but I think I am over fifty. I was educated first in the Church of Scotland Mission and after that I educated myself. I am a Christian. ${ }^{113}$ Whilst

\footnotetext{
${ }^{111}$ Wepman, Dennis, Jomo Kenyatta, London, 1988, p. 107

${ }^{112}$ Meredith, pp. 264 - 274

${ }^{113}$ Kenyatta, Jomo, in Arnold, p. 15
} 
his birthdate remains ambiguous - we do know that Kenyatta was born sometime between 1890 and 1895, in the Gatundu division of Kiambu - a province adjacent to Nairobi in central Kenya. At the time this was contained within what was called British East Africa or the East Africa Protectorate. Kenyatta's name at birth was Kamau wa Ngengi (Kamau the son of Ngengi). ${ }^{114} \mathrm{He}$ was born a member of agriculturalist Kikuyu tribe. At age twelve he commenced five years of formative education at the local Church of Scotland Mission. As Kenyatta developed he began to take issue with the European education he was receiving. He believed it 'never tried to understand the importance of a customary Kikuyu upbringing'; he argued it was 'people-oriented unlike European education which [was] knowledge oriented. ${ }^{\prime 15}$ At the outbreak of World War One, Kenyatta left his Church of Scotland education for Nairobi. Here he discovered a small and elite group of similar young Africans 'who possessed a thin veneer of Western Christian education added to their tribal upbringing. ${ }^{, 116}$

According to Arnold, Nairobi at the time of Kenyatta's arrival was more akin to an American frontier town than anything distinctly African. It was the heart of Kenya's European settler economy and political system. For such a young town, only established in the early $20^{\text {th }}$ century, Nairobi's settler population were remarkably political. In the capacity of Colonial Under-Secretary, Winston Churchill observed that;

Every white man in Nairobi is a politician; and most of them are leaders of parties. One would scarcely believe it possible, that a centre so new should be able to develop so many divergent and conflicting interests, or that a community so small should be able to give each such vigorous and even vehement expression. There are already in miniature all the elements of keen political and racial discord, all the materials for acrimonious debate. ${ }^{117}$

\footnotetext{
${ }^{114}$ Arnold, Guy, Kenyatta and the Politics of Kenya, London, 1974, p. 15

${ }^{115}$ Ibid, p. 16

${ }^{116}$ Ibid, pp. 16-17

${ }^{117}$ Churchill, Winston, 1907, in Murray-Brown, Jeremy, Kenyatta, London, 1972, p. 62
} 
Nairobi was also a town where African frustrations toward settlers and their administration were beginning to ferment. Kenyatta's biographer Jeremy MurrayBrown notes that acts of cruelty by settler landowners and businessmen towards the various tribes-people were openly shared and discussed by Africans at Nairobi's markets - where 'old men [would] shake their heads over their beer and the young men's anger [would] rise.'118 These were the nascent issues that would eventually frame Kenyatta's leader-follower relationship. At the time of Kenyatta's arrival, the colonial centre of Nairobi was also exhibiting key elements of Frederick Greenstein's political environment of potential restructuring - where an array of forces were beginning to arrange themselves consciously and subconsciously in preparation for an epic political confrontation for the future of the territory.

The political forces that were mobilising around Nairobi to decide the future of the East African Protectorate were halted by the outbreak of World War One. With German colonies located throughout Africa, the British effort mostly revolved around their submission and acquisition. Murray-Brown notes that the war in East Africa 'turned out to be a watershed in Kenya's history. ${ }^{119}$ As World War One played itself out both locally in East Africa and internationally, a situational context evolved which further enhanced the environmental restructuring present (to use the Greenstein approach). This was one where key political actors - leaders and followers - were increasingly 'activated' (to employ Burns). From the perspective of the British settlers in East Africa, the First World War made it plainly obvious that as soon as the Suez Canal was closed - their pioneering agricultural operations in the Kenyan highlands were virtually cut-off, and their essential supplies had to be sourced from either South

\footnotetext{
${ }^{118}$ Murray-Brown, Jeremy, Kenyatta, London, 1972, p. 63

119 Ibid, p. 69
} 
Africa or India. 'The concept of a viable, self-governing white state in the African highlands was shown to be an absurdity. ${ }^{120}$ This subsequently motivated the settlers, possibly out of insecurity, to an endeavour to attain more control of the policy process in the territory from the beleaguered Colonial Administration in East Africa. Their efforts were successful in the context of war and the settlers achieved a measure of control over their own affairs. This ran counter to the official policy of the Colonial Office. ${ }^{121}$ The Colonial Office was instead trying to move toward 'multiracialism' for East Africa. ${ }^{122}$ This was also indicative of a theme in the previous chapter - that the British Empire was by no means homogenous in how it manifested itself.

The war also saw a significant shift in the political orientation of the African majority. At the outbreak of the conflict the African population were told that King George's enemies were threatening them. In light of this, many immediately offered their support and participation in the war effort. ${ }^{123}$ All of the populous tribes in the protectorate were recruited from; the Kikuyu from around Nairobi, the Luo from near Kisumu and the Kamba and Swahili from around Mombasa. The extent of African participation was staggering - Murray-Brown estimates that from some areas around $75 \%$ of the male population were involved in the war effort. ${ }^{124}$ This devastated village life those areas. 'Few ridges of Kikuyuland escaped the impact of recruitment into what were little more than slave gangs. ${ }^{125}$ These upheavals created an environment where traditional tribal life, certainly the tribal economy, was shattered. At the same time, groups of tribes-people who had been at war with each other only a generation

\footnotetext{
${ }^{120}$ Murray-Brown, p. 69

${ }^{121}$ lbid, p. 70

${ }^{122}$ Chidzero, B. T. G., 'African Nationalism in East and Central Africa, in International Affairs (Royal Institute of International Affairs), Volume 36, Number 4, 1960, pp. 464 - 475

${ }^{123}$ Murray-Brown, p. 70

124 Ibid.

125 Ibid.
} 
ago - were in the British columns together to fight a common enemy. This was a major reorganisation of African society in British East Africa. It would significantly change the political environment in the post-war era through its impact upon the psychological predispositions and motivations of the African population.

One of the many ways that the war impacted on the indigenous populations of East Africa was it generated a labour shortage; making it easier for Africans not engaged in the conflict to find employment the urban areas of the territory. Educated young men like Jomo Kenyatta fared especially well. 'Those with mission training had little difficulty finding jobs in offices or on deserted farms. ${ }^{126}$ Kenyatta was first employed in a sisal company by the charismatic European, John Cook - who was already popular with young African's from the mission schools. When analysing independence leaders it could be useful to look to the existence of any positive encounters with Europeans during their political development. This may deliver some insight into those who pursued conciliatory policies with the European settler and those who did not. Kenyatta could not stay with Cook for long as he had a serious bout of ill-health and was obliged to approach his close friend Charles Kasaja for medical assistance. This particular bout of ill-health enabled Kenyatta to avoid the increasingly desperate British conscription sweeps of the African community, as they searched for manpower to aid in the East African war. Murray-Brown notes that as part of the British final effort to defeat the German armies in Africa - 'all unemployed males were driven at the point of bayonets into service. ${ }^{127}$ It was these British conscription 'sweeps' that drove many Kikuyu to seek salvation in the territory of the proud and nomadic Masai people - Kenyatta was one of them. 'Among the Masai a man could lie low. The fire of

\footnotetext{
${ }^{126}$ Murray-Brown, p. 70

${ }^{127}$ Ibid, p. 72
} 
recruitment would not spread there, for the Masai were too dispersed for close administration and too fierce for casual interference. ${ }^{128}$ The Kikuyu and the Masai were traditional enemies; this was yet another example of how the British East African policy during the war unintentionally broke historical tribal animosity - and to an extent made Britain the 'common oppressor.' To employ Burns, this amalgamation of motivations within the followership would later provide the independence leader with a vital avenue to deliver 'activating' leadership through tapping into common motivations and experiences.

At the conclusion of the African campaign - culminating in the British acquisition of 'The German East,' or what was known as Tanganyika, Kenyatta moved back to Nairobi. Murray-Brown notes that Nairobi had a magnetic effect on Kenyatta when he was in his twenties. ${ }^{129}$ Kenyatta had already proven how readily he could adjust to the new urban life of Nairobi. As a young, relatively educated African he was able to earn good money and master the new and emerging economic conditions in his fatherland. Twenty years earlier Kenyatta was carried around by his mother in a goatskin, deeply immersed in the traditional Kikuyu world - by 1918 he was, along with many of his kinsmen, in a completely different universe. British East Africa was changing rapidly, and Kenyatta was of the right age and constitution to take advantage.

\section{$\underline{\text { Nationalist Agitator }}$}

As Kenyatta was enhancing his social and economic mobility, as part of the emerging African elite, political activity became more common among the indigenous population in the East Africa Protectorate (or Colony of Kenya as it was renamed in 1920). A series

\footnotetext{
${ }^{128}$ Murray Brown, p. 73

129 Ibid, p. 75
} 
of actions undertaken by the British Administration fermented his generations' political consciousness For example, the 1920 Registration Act introduced the kipande or identity-certificate system for all African males of sixteen or over. It obliged them to carry registration cards on which their finger prints had been impressed. This was so that they could be more easily controlled. ${ }^{130}$ Arnold argues that the 'kipande system,' and the system of 'Hut Taxes' (Africans were taxed on the number of huts they owned) - were two of the main issues taken up by the new generation of politically interested Africans. $^{131}$

A post-war economic slump in the region further augmented established African frustrations. In response to the slump, the settlers demanded the local administration significantly reduce the wages that Africans were paid. This was naturally resented by the African population. These resentments were also exacerbated by African's nonrepresentation in the government. ${ }^{132}$ The discontent had reached sufficient pressure for an outlet to be necessary and on June 11, 1921, a young Kikuyu, Harry Thuku, proposed the creation of the Young Kikuyu Association. It was created to advocate against any offensive government policy toward the Kikuyu people. ${ }^{133}$ Other associations had emerged around the same time, and though they had significant differences, they were united by the same sense of grievance over a number of issues. Arnold articulated these issues included; 'forced labour, or its near equivalent, the fact that those who had served in the war had been told that they would be rewarded afterwards and instead found themselves with increased taxes and the kipande

\footnotetext{
${ }^{130}$ Arnold, p. 18

131 Ibid.

132 lbid, p. 19

133 Ibid.
} 
system; and, finally the proposed reduction in wages. ${ }^{\prime 134}$ The colonial authorities entertained Thuku for a time, however in 1922 when he had achieved noticeable agitation - he was arrested and exiled. His organisation had to reform itself and was renamed the Kikuyu Central Association (KCA).

In 1924 Jomo Kenyatta joined the organisation. His involvement in the KCA escalated when the Association launched its own paper, 'Muigwithania' or 'the Reconciler.'135 The paper needed a kikuyu editor with a strong command of the English language. Kenyatta was the obvious choice. Muigwithania was the first newspaper written for African's living in the East Africa Protectorate and it was widely read across the territory. ${ }^{136}$ Arnold notes that Muigwithania had dual effects; it united the progressive elements among the African community, whilst it also served a tribal nationalist purpose. Muigwithania employed riddles, proverbs and stories that were intended to foster pride in being both Kikuyu and African. ${ }^{137}$ It was at Muigwithania that Kenyatta began to develop his ability to tap into the existing, and nascent, political forces among the African population. At Muigwithania Kenyatta became recognised as a voice of African discontent. This conforms to Burns' and Greenstein's prisms for the analysis of leadership. Kenyatta was located in an environment where he could represent and articulate the concerns of African's in a way that achieved mutual stimulation. The maturing of this leadership skill was, however, decades away.

At the end of the 1920's a major political crisis emerged in the East African Territory. It would be the first to genuinely activate Kenyatta's leadership capabilities. The Kikuyu practice of female circumcision had long been regarded by Europeans, and especially

\footnotetext{
${ }^{134}$ Arnold, p. 19

135 Ibid, p. 22

136 Ibid.

137 Ibid.
} 
the missions, as both pagan and abhorrent. ${ }^{138}$ The Church of Scotland Mission, where Kenyatta had received his education, led the demands for the ending of the custom. Kenyatta led the opposition and sought to preserve tribal autonomy. ${ }^{139}$ Arnold argues that this would be a situation typical of the anti-colonial struggle, where 'the mission educated boy later [used] his education and knowledge to attack the position of the mission. ${ }^{140}$ Kenyatta proved effective in this role - organising an articulate and assertive resistance. He naturally lost favour with his former mission and was expelled from the Church.

\section{London}

Kenyatta had proven his ability as a political representative and organiser. He had also demonstrated his loyalty and affiliation to the cause of African (more specifically Kikuyu) nationalism. As a consequence he was sponsored by the KCA to go to Britain and represent Kikuyu grievances on their behalf. Murray-Brown notes that 'nothing that an African might see in the silent movie houses of Nairobi or the pages of English magazines could have prepared Kenyatta for the reality of Europe's largest city. ${ }^{141}$

As mentioned in the previous chapter there was a distinction between Britain's West African, and the Eastern and Southern colonies. This distinction was highlighted when Kenyatta reached London. As Martin Meredith noted, 'Britain's West African Territories were the most advanced... In Britain's colonies in East and Central Africa, political activity revolved around the demands of white settlers. ${ }^{142}$ Kenyatta was to become intimately involved with a group of West Africans who demonstrated much

\footnotetext{
${ }^{138}$ Arnold, p. 23

139 Ibid.

140 Ibid, p. 23

${ }^{141}$ Murray-Brown, p. 114

${ }^{142}$ Meredith, p. 11
} 
higher levels of political development in ideas and demands for self-government. Murray-Brown mused that 'for someone coming straight from the settler-dominated territories of East and Central Africa, such views were revalational. Only white men talked about self-government there; it was not a KCA objective. ${ }^{143}$ For the first time in Kenyatta's life he was exposed to Africans of a higher intellectual attainment than his own. Some of his West African companions in London were fully qualified barristers and accomplished writers. Murray-Brown notes that Kenyatta was insecure in their company. 'They had no common experience except their black skins and no common language [aside from English] which he spoke slowly, whereas they had picked up the latest idiom of debate. ${ }^{144}$ Kenyatta was initially intimidated by the task before him as an advocate at Whitehall. It was obvious to him that he was not being taken seriously by the British administrators, or even his West-African contemporaries. The employment of Greenstein's approach here holds that as a potential leader, Kenyatta's strategic location within such an entrenched and oppressive political context limited his ability to advocate for his people. Murray-Brown reflects that despite this (and the London weather) Kenyatta's spirit was not dampened, he 'had the money raised by the KCA and ample self-confidence in his destiny. He was ready to embark upon a new phase of his life. ${ }^{145}$

With meagre support from the West African's, Kenyatta turned to some influential and sympathetic members of the British Labour Party to advance his cause. W. McGregor Ross and Norman Leys formed what Murray-Brown refers to as the nucleus of a growing body of influential opinion in the British Labour Party. ${ }^{146}$ On behalf of

\footnotetext{
${ }^{143}$ Murray-Brown, p. 115

${ }^{144}$ Murray-Brown, p. 115

145 Ibid.

146 Ibid, p. 116
} 
Kenyatta, these men organised him a meeting with the Governor of the Kenya Colony, Edward Grigg. As the Governor was removed from Nairobi, and its political atmosphere, he agreed to meet with Kenyatta and hear out the KCA's grievances. From this meeting at the offices of the Rhodes Trust, Kenyatta was successful in securing the release of Harry Thuku (though on a non-committal time frame). Kenyatta was, however, unsuccessful in getting the Governor to move on the issue of land more specifically on the Governor's 'Native Lands Trust Bill,' which provided for the creation of tribal reserves rather than allowing Africans individual title and deeds. ${ }^{147}$ Governor Grigg asserted that the Kikuyu 'must learn to patiently argue their views out through local councils. ${ }^{148}$ Grigg added, that was going on at the same time in Britain. ${ }^{149}$ Unbeknown to Kenyatta, these talks were non-binding as the Governor was not acting in his official capacity as he was out of the colony. This scuttled Kenyatta's hopes of securing meaningful concessions from the Colonial Administration. ${ }^{150}$ Kenyatta was once again alienated from any strategic location to achieve historical impact - to further employ Greenstein.

This was the most tenuous phase in Kenyatta's leadership career. At the same time as his failure to achieve meaningful advocacy became apparent, news was spread of Kenyatta being 'out of his depth,' and engaging with prostitutes in his spare time. ${ }^{151}$ Some contemporary observers of Kenyatta believed that they had seen the end of him when he disappeared, without explanation, on a trip to Moscow. This trip to Moscow was, however, not the end of the young Kikuyu. In 1929 Moscow was the capital of a recently united and communist Russia under Stalin. It was also a hotbed of radical

\footnotetext{
${ }^{147}$ Murray Brown, pp. $116-117$

148 Ibid.

149 Ibid.

150 Ibid, p. 118

${ }^{151}$ Ibid, p. 119
} 
Marxist thought which informed a fairly savage critique of imperialism - and therefore the British Empire's African extensions. On his first encounter with this environment, Kenyatta picked up the rhetoric. His first article published after he got back from Moscow, in 'The Daily Worker,' included soaring 'language of abuse.' ${ }^{152}$ Kenyatta wrote, 'The present situation means that once again the natives of the colony are showing their determination not to submit to the outrageous tyranny which has been their lot since the British robbers stole their land. ${ }^{153}$ These were words far stronger than anything ever heard from Kenyatta, or the KCA. He went on to assert 'discontent has always been rife among the natives, and will be so until they govern themselves. ${ }^{154}$ These ideas would form the substantial basis of Kenyatta's political message for the next thirty years. ${ }^{155}$ Despite the scandals around his consumption of prostitutes, or talk of his incapability to represent Africans, Kenyatta's political career gained momentum. He was endowed with a message that began to achieve resonance in interested circles in Britain - as well as back in East Africa. Here the researcher can observe James McGregor Burns' leadership theory in play. Kenyatta had discovered a message that had the potential to engage with the followership through tapping into nascent issues, and thus triggering their political consciousness. Kenyatta began to broadcast an idea that had the potential to ignite the interests and passions of a followership that could become responsive to his leadership. To synthesise this further with Greenstein's approach - when Kenyatta came back from Russia and introduced the rhetoric of self-government, the 'billiard balls' began to move.

\footnotetext{
152 Murray-Brown, p. 120

${ }^{153}$ Kenyatta, Jomo, 1929, in Ibid, p. 120

154 Murray-Brown, p. 120

155 Ibid.
} 
In an effort to try and keep Kenyatta from falling into a state of permanent hostility towards the British establishment, the Labour politicians organised a meeting with the Under-Secretary of State of the Colonies, Drummond Shiels. Shiels and Kenyatta agreed that the education of the African population in the Kenya Colony was fundamental to the advancement of African interests. At the meeting he told Kenyatta he was glad 'to see the stress that you lay on education. Unless you have an educated people to deal with, you may have the misfortune to put into force influences that you cannot control, and grave disaster to all your hopes may result. ${ }^{156}$ Shiels' parting advice to Kenyatta was in line with the Labour politicians - they encouraged him to go back to Kenya and advocate for 'ordered constitutional advance,' rather than extremism or revolution. ${ }^{157}$ This concept of ordered constitutional advance was almost immediately undermined by Governor Grigg's announcement to an assembly of Kikuyu elders that he intended to ban the collection of funds by Africans for the operation of political associations. This would effectively choke off the funds supporting Kenyatta's advocacy in London. Murray-Brown asserted that Grigg also investigated the possibility of supressing 'vernacular newspapers, while also making moves to limit the rights of African's to hold political meetings and make speeches. ${ }^{158}$ The Governor also established an elaborate intelligence system for the further subjugation of indigenous political activity. ${ }^{159}$ This demonstrates a cleavage that existed between a more enlightened and long term vision emanating from the Colonial Office in London, and the somewhat reactionary colonial administration on the ground.

\footnotetext{
${ }^{156}$ Shiels, Drummond, 1930, in Murray-Brown, p. 122

${ }^{157}$ Murray-Brown, p. 122

158 Ibid.

159 Ibid, pp. 122 - 123
} 
Governor Grigg was exercising his rights and powers as the governor of the colony, though he was not conforming to the overall British policy for the region - which was for the gradual increase in African participation in civic process. This aligns with a theme from literature analysed in the previous chapter. The Governor, while still a British civil-servant, was endowed with substantial and far-reaching autonomy in the colonial context, mandating him to take actions and pursue courses with limited accountability to the Colonial and Foreign Offices in London. Tensions between the Governor and the Colonial Office in London were exacerbated in the summer of 1929 when the new Labour Government under Ramsey MacDonald sought to pursue a significantly more progressive policy toward the East African colonies. The progressive approach of the Labour Government starkly contrasted its Conservative predecessor.

Despite progressive ideas emanating from London, Murray-Brown asked the question; 'could democratic theory ever be reconciled with colonial practice? To give British imperial policy a new and radical direction was an exciting aim... But the colonial structure was in its very nature authoritarian and its civil servants were by training and background conservative. ${ }^{\prime 160}$ This meant that any progressive intentions with regard to the colonies were likely to be hamstrung by the inertia that existed within the imperial system. Historian Caroline Elkins supports this claim about the colonial operators in contrast to any London progressives. Colonial officials 'were [often] handpicked... in targeted recruitment campaigns that openly sought future colonial rulers with backgrounds common to the dominant ruling class in Britain. ${ }^{161}$ This disjunction was further complicated by the devolution of the power structure - empowering the colonial governors and district commissioners to 'interpret' colonial policy in a way

\footnotetext{
${ }^{160}$ Murray-Brown, p. 123

${ }^{161}$ Elkins, Caroline, Britain's Gulag - The Brutal End of Empire in Kenya, 2005, London, p. 8
} 
which suited their own governing predispositions. This meant that while the Labour politicians were endeavouring to convince Kenyatta to take a constitutional path toward the political empowerment of Africans, the actions of Governor Grigg and his administration forced Kenyatta in an opposing, more radicalised, direction. This supports Burns' claim in the previous chapter regarding the tenacious inertia of institutions -and the extent to which they can frustrate reforming leadership.

At the behest of the Labour politician McGregor Ross, Kenyatta wrote (or allowed Ross to publish in his name) a letter to the editor of the Manchester Guardian outlining his hopes for Kenya. The letter was deeply constitutionalist in that it sought a redress Kikuyu grievances from within the British governing framework. ${ }^{162}$ Murray-Brown argues that Kenyatta's decision to moderate himself and pursue the constitutionalist path was in part motivated by a desire not to return to Kenya and suffer the same fate of his KCA predecessor Harry Thuku, in exile ${ }^{163}$. The letter did, however, include an ominous warning to all interested parties: 'The repression of native views, on subjects of such vital interest to my people, by means of legislative measures, can only be described as a short-sighted tightening up of the safety valve of free speech, which must inevitably result in a dangerous explosion - the one thing all sane men wish to avoid. ${ }^{164}$ Unfortunately for the constitutionalist reformers this 'explosion' prophesy was to manifest itself in the Mau Mau emergency.

In the autumn of 1930 Kenyatta took the risk of returning to Kenya, which coincided with the conclusion of Governor Grigg's tenure. He received a hero's welcome at the port city of Mombasa. In his absence the organisation he was representing, the KCA,

\footnotetext{
${ }^{162}$ Murray-Brown, pp. $126-127$

163 Ibid, p. 125

${ }^{164}$ Kenyatta, Jomo (Ross, W. McGregor), Manchester Guardian, $18^{\text {th }}$ March, 1930, in Murray-Brown, p. 127
} 
had flourished. ${ }^{165}$ The Association had even opened branches as far south as Tanganyika (Tanzania). ${ }^{166}$ It was clear that Kenyatta's message, broadcast from London, had activated a Burns style 'followership.' Kenyatta had tapped into a common sentiment among Kikuyu and now other ethnic groups within Kenya. This empowered the activist core that the KCA needed to obtain traction in their struggle for greater political representation and authority in Kenya. One can also trace some of Maslow's theory here. The 'esteem needs' of the non-settler ethnic groups of Kenya were motivating them to articulate their increasingly vociferous demands for change. Kenyatta was to become increasingly successful in being the voice of such demands.

The KCA chose to return Kenyatta to England in 1931. The purpose of this representative mission was for Kenyatta to 'present evidence at the Parliamentary Joint Committee on Closer Union in East Africa. ${ }^{167}$ Guy Arnold asserts that the KCA was deeply opposed to such a Union as they legitimately feared it would establish a South African style settler government in East Africa. Unfortunately for the KCA and Kenyatta, the Committee had concluded its hearing of witnesses by the time of his arrival, though it unofficially allowed Kenyatta to deliver the Committee the KCA document of evidence. ${ }^{168}$ With his official business in London concluded, Kenyatta proceeded to remain in the capital of the British Empire for a subsequent sixteen years. Jeremy Murray-Brown notes that this was in large part because 'in London he was a free man, in Nairobi the subject of a totalitarian state. ${ }^{169}$ Writing retrospectively in Suffering Without Bitterness Kenyatta asserted that he chose to remain in London for the fulfilment of two objectives; to broaden his experience by becoming a student

\footnotetext{
${ }^{165}$ Arnold, p. 26

166 Ibid.

${ }^{167}$ Arnold, p. 26

168 Ibid, p. 27

${ }^{169}$ Murray-Brown, p. 133
} 
of anthropology and economics, and to be continuous representative of his people through attacking colonialism and 'the colonial attitudes at the centre of the British Empire. $^{170}$

On Kenyatta's return to London he enrolled in the London School of Economics to further his education, whilst still receiving material support from the Labour politician McGregor Ross. Kenyatta's academic career reached its zenith with his 1938 publication of Facing Mount Kenya; an anthropological study of the Kikuyu people. Murray-Brown asserts that Facing Mount Kenya was unprecedented in that 'no other African had made such an uncompromising stand for tribal integrity. ${ }^{171}$ The Ghanaian historian A.B. Assensoh notes that during this phase of Kenyatta's development he established close ties with African nationalists such as Kwame Nkrumah, Felix Houphouet-Boigny, J B Danquah and Ladipo Solanke. ${ }^{172}$ Assensoh and Murray-Brown both acknowledge that throughout this student-academic phase, Kenyatta 'learned the rudiments of colonial politics as well as Pan-Africanist organisation., ${ }^{173}$

The outbreak of World War II generated a familiar hostility of the colonial authorities toward dissenting political organisations such as the KCA. On the $30^{\text {th }}$ of May, 1940 the Colonial government in Kenya 'proscribed the KCA, alleging that it had established a treasonable relationship with Italian agents. ${ }^{, 174}$ This did not culminate in Kenyatta's arrest in London, though much of the KCA leadership back in Kenya were 'restricted.' ${ }^{175}$ The proscription did result in the freezing of the KCA funds that supported Kenyatta in London - his response was to take Englishwoman Grace Clark as

\footnotetext{
${ }^{170}$ Kenyatta, Jomo, Suffering Without Bitterness, Nairobi, 1968, p. 33

${ }^{171}$ Murray-Brown, p. 193

${ }^{172}$ Assensoh, A.B., African Political Leadership, Florida, 1998, p. 53

${ }^{173}$ Assensoh, p. 53

${ }^{174}$ Arnold, p. 29

175 Ibid.
} 
his second wife (he was also married to Grace Wahu back in Kenya), and to move to the countryside and work as a farm labourer. ${ }^{176}$ Arnold notes that life in rural England suited Kenyatta; he became popular with the locals and was a regular customer at the village pub.

Toward the conclusion of the war Kenyatta began to reactivate his political career. With the KCA still a banned organisation in Kenya, Jomo Kenyatta used the avenue of the Pan-Africanist movement to attain political traction. In 1945 Kenyatta was elected the President of the $5^{\text {th }}$ Pan-African Congress, commencing his sharp rise to political prominence in the post-war era. In the performance of this role, Arnold notes that he was described contemporaries as 'sane, humorous and intelligent. ${ }^{177}$ Kenyatta's involvement in the congress framed his conclusion that the reformist and constitutional path, as advocated by his Labour Party associates, no longer made sense. He wrote in his autobiography that it was at this time he decided that the paramount design must be to unite all the people of Kenya, and that the purpose must be nothing short of independence. ${ }^{178}$ This shift in Kenyatta's approach conforms remarkably well to Burns' leadership thesis, demonstrating the frustrations of reforming leadership, and how Kenyatta was now sufficiently radicalised to pursue a more revolutionary path. Burns mused that 'the reformer seeks modifications harmonious with existing trends and consistent with prevailing principles and movements. The revolutionist seeks redirections, arrest or reversal of movements and

\footnotetext{
176 Ibid, p. 30

177 Arnold, p. 31

${ }^{178}$ Kenyatta, Jomo, Suffering Without Bitterness, Nairobi, 1968, p. 47
} 
mutation of principles. ${ }^{179}$ Kenyatta was now on a revolutionary path, and with no warning in 1946 Kenyatta returned to Kenya.

\section{$\underline{\text { The Mau Mau }}$}

In 1948 a District Commissioner from Nakuru, in the Rift Valley, made the first mention of what he believed was a 'sinister secret society. ${ }^{180}$ In his annual report he gave this organisation the name Mau Mau. Meredith asserts, 'it was a name which in the Kikuyu language was meaningless. Its origin was lost in the Kikuyu passion for riddles. ${ }^{, 181}$ Martin Meredith notes that the colonial officials thought they were dealing with a secretive minority, when in reality they were facing 'an incipient revolt among the Kikuyu for which Mau Mau became, by common usage, the fearsome expression. ${ }^{182}$ The discontent that drove the Mau Mau into existence had been brewing for decades. Meredith notes that such discontent was increased the Colonial Administration's requirement for the indigenous population, especially the Kikuyu, to vacate Kenya's most fertile lands in the White Highlands, to make way for white immigrants. 'Facing the loss of land and grazing rights and the destruction of their communities, the squatters embarked on a resistance campaign, binding themselves together with secret oaths. ${ }^{183}$ Settler pressure on indigenous communities was further exacerbated with the arrival of some 8,000 European migrants, escaping post-war austerity. Many of them were ex-World War II servicemen. The indigenous political milieu was one on the verge of rebellion. To employ Greenstein's theoretical approach; Kenyatta landed in a political environment where there was powerful potential for restructuring.

\footnotetext{
${ }^{179}$ Burns, p. 170

${ }^{180}$ Meredith, p. 83

${ }^{181}$ Meredith, p. 83

182 Ibid.

${ }^{183}$ Ibid, p. 82
} 
Furthermore, Burns' thesis explains the leadership context in that when Kenyatta returned to Kenya he was immediately exposed to a dynamic and engaged followership, a followership whose political consciousness had been activated by rhetoric against the colonial government, and against the settlers.

Kenyatta rapidly immersed himself in grass-roots politics. He assumed the leadership of the pre-established Kenya African Union (KAU) - a pan-tribal organisation established two years before his return, for the purpose of campaigning for African rights. The organisation represented the reality that political consciousness in Kenya had morphed away from sectional tribal interests, into a nationwide struggle for change. As leader of the KAU Kenyatta was soon captivating the crowds that flocked to listen to him with his 'forceful personality, his powers of oratory and his flamboyant manner. ${ }^{\prime 184} \mathrm{He}$ became the focus of political intrigue in Kenya, his rhetoric about Britain and the future of Kenya was captivating to the multitude of Kenyans with whom his message resonated. ${ }^{185}$ Once again, Burns' theory can be observed, Kenyatta was raising the political consciousness of the followership through the mobilisation of shared ideas, values, and more importantly, grievances. In 1964 in Mau Mau Detainee, J. M. Kariuki wrote, 'he was mixing Kikuyu and Swahili words in a wonderful way., ${ }^{186}$ Kenyatta was also successful in arresting the concerns of many Africans that he had become too immersed in the London world and had lost touch with the life of the Kikuyu. Karuiki noted that this success was a result of his overlaying of his political message with traditional Kikuyu phrases, 'the doubters found that he knew more old Kikuyu phrases than they had ever heard. ${ }^{187}$ To employ Burns' method of analysis, this

\footnotetext{
${ }^{184}$ Meredith, p. 83

${ }^{185}$ Arnold, p. 32

${ }^{186}$ Kariuki, J. M., Mau Mau Detainee, London, 1964, p. 37

187 Ibid.
} 
allowed Kenyatta a deeper moral engagement with the followership - and this increased the potency of his leadership.

The Colonial Administration, and the settlers on whose behalf it mainly acted, was alarmed at the resonance of Kenyatta's call for African unity. The demands he was making on behalf of his people were unpalatable to the Administration and therefore they set out to destabilise Kenyatta's authority and standing. ${ }^{188}$ Guy Arnold writes that 'white Kenya... made determined efforts to destroy his charisma,' ${ }^{189}$ this was often done through references to his 'eloping' to Russia during his time in London. The narrative the authorities were attempting to build around Kenyatta had little sticking power with consideration to the mood of the indigenous population. According to former Colonial Officer F.D. Corfield, it was at this time in Kenyatta's leadership development that he became, 'to officials and non-officials... the dominant personality in the African scene. ${ }^{190}$ Consideration here is given to Kenyatta's enhanced strategic location due to the high levels of environmental restructuring present.

Kenyatta was, however, unsuccessful in employing his rising personal prestige to control an emerging militancy among Kikiuyu. Their frustrations at the actions of the Administration radicalised them well beyond where Kenyatta was prepared to lead them. Meredith writes that Kenyatta 'was outflanked by militant activists prepared to use violence. ${ }^{191}$ These activists successfully acquired enough influence in the KAU to increase the frequency of violent attacks and sabotage against the Administration and the settlers. This shift toward the violence, Meredith argues, 'split the Kikuyu

\footnotetext{
${ }^{188}$ Arnold, p. 33

189 lbid.

${ }^{190}$ Corfield, F.D. Historical Survey of the Origins of the Mau Mau, London, 1960, p. 102

${ }^{191}$ Meredith, p. 85
} 
people ${ }^{192}$ Historian Caroline Elkins asserts that the split within the Kikuyu people was between a 'rich but tiny chiefly minority and the majority, who had endured not just exploitation but loss of land and status under British rule. ${ }^{193}$ This situation was a typical result of British colonial practice. The minority of chiefs had been made exceptionally wealthy by the Colonial Administration in exchange for their continued collaboration and support for the regime. British policy choices intended to manage Kikuyu agricultural practices in their designated reserves had enflamed the Kikuyu populous beyond the control of their chiefs, and also of Kenyatta infleunce. British action had made the milieu so volatile that not even the emergent leadership of Kenyatta could steer the 'environmental restructuring' present, or play an effective shot on Greenstein's billiard table.

To add insult to injury, Kikuyu World War II veterans, who had served in the Middle Eastern and India/Burma theatres of war, found that their British counterparts were receiving 'demobilisation support from the Colonial Administration, in the form of land, low interest loans, and job creation programmes. ${ }^{194}$ The Kikuyu veterans were dismayed to discover that while the British veterans enjoyed these benefits, their own fortunes (and those of their tribes-people) were in steady decline. ${ }^{195}$ The squatter clearances of the White Highlands forced thousands of squatters off European farms and created 'an agitated group of homeless and property-less people in a land they considered to be their own. ${ }^{196}$ These sources of popular discontent combined with overcrowding and unemployment in Nairobi and other urban centres, generated the

\footnotetext{
192 Ibid

${ }^{193}$ Elkins, p 23

194 Elkins, p. 25

195 Ibid

196 Ibid
} 
elements of the 'dangerous explosion' which Kenyatta had prophesied over for some time.

Elkins notes that it was not Kenyatta or the KAU leadership that initiated the mobilisation of the Kikuyu masses to open rebellion against colonial rule, rather the catalyst was a group of several thousand evicted squatters that had settled in area called Olenguruone. It was this group that instigated the widely practised 'oathing' that would become synonymous with the 'Mau Mau Emergency.' Elkins asserts 'Kikuyu men had taken an oath to forge solidarity during times of war or internal crises; the oath would morally bind men together in the face of great challenges. ${ }^{197}$ MurrayBrown notes that 'oathing added secrecy to a political situation that was already fluid. ${ }^{198}$ The secrecy of the system fuelled the paranoia of the Colonial Administration and the settlers; paranoia further exacerbated by the increase in violent resistance by men who had taken the oath. In 1950 the Kenya Colony African Affairs Department noted that 'secret meetings were being held in which an illegal oath, accompanied by appropriately horrid ritual, was administered to initiates binding them to treat all Government servants as enemies, to disobey Government orders and eventually to evict all Europeans from the country.'199

Martin Meredith asserts that Kenyatta tried to 'ride out the turbulence, seeking to defuse the crisis rather than stir it up., ${ }^{200}$ This was done in part, as Murray Brown notes, through seeking to moderate the militant faction of KAU leaders that had taken control of the organisations direction. ${ }^{201}$ Historian David Anderson asserts that;

\footnotetext{
${ }^{197}$ Elkins, p. 25

${ }^{198}$ Murray-Brown, p 241

${ }^{199}$ KNA, African Affairs Department, Annual Report, 1950, p. 2

${ }^{200}$ Meredith, p. 85

${ }^{201}$ Murray-Brown, p. 242
} 
'though few Europeans believed it at the time, Kenyatta's protestations that he had done all he could to thwart the militants were true. ${ }^{202}$ Unfortunately for Kenyatta, the militant factions were using Kenyatta's name and personal prestige to justify their actions. Murray-Brown notes that the militant factions of the KAU and the now emergent Mau Mau leadership 'used Kenyatta's name freely in their propaganda.'203 This further limited Kenyatta's ability to control the events on the eve of the Mau Mau uprising. Colonial Authorities and the radical factions within the KAU treated Kenyatta with equal suspicion. Kenyatta's grip on the hearts and minds of the Kikuyu people was never compromised, despite that behind the scenes the young militant faction, rather than his own moderate faction, was shaping the direction of Kikuyu, and indeed African politics in Kenya. ${ }^{204}$ The political environment, or situational milieu had become so fluid, and undergoing such intense restructuring, that Kenyatta's leadership was rendered relatively impotent.

By 1952 Kenyatta was asked by the Colonial Government to denounce the violence and intimidation of the Mau Mau, a request he duly accepted. Kenyatta's denunciation of the Mau Mau naturally affected a hostile response from those in control of the KAU; fellow nationalist Fred Kubai recalled, 'If Kenyatta had continued to denounce Mau Mau, we would have denounced him. He would have lost his life. It was too dangerous and he knew it. He was a bit shaken by the way we looked at him. He was not happy. We weren't the old men he was used to dealing with. We were young and we were serious. ${ }^{205}$ Kenyatta's political leadership was dangerously located between a militant controlled KAU and an increasingly intimidated and hostile Colonial Administration. To

\footnotetext{
202 Anderson, David, Histories of the Hanged - The Dirty War in Kenya and the End of Empire, London, 2005, p. 41

203 Murray-Brown, p. 424

204 Murray-Brown, p. 243

205 Kubai, Fred, 1952, in Meredith, p. 85
} 
apply Greenstein's leadership framework here, the situational array was incredibly oppressive for Kenyatta, and despite the universal adoration he was receiving from his followers (Burns framework also applicable), he did not have the unique blend of skills to navigate this milieu. As referenced above, Greenstein theorised about a leader's historical impact being amplified by a political environment of high restructuring. This case moves beyond that assertion, indicating that an environment can be restructuring itself at too fast a rate for a leader to shape direction and therefore make any significant historical impact. The thesis of Abraham Maslow can assist in this analysis. The highland squatter clearances directly threatened the satisfaction of the basic human needs of safety, shelter and food of many Kikuyu, thus triggering Maslow's 'emergency response.' This could well explain one of the major radicalising forces among the followership - one that took them beyond the direct leadership of Kenyatta.

This was not, however, the conclusion of Kenyatta's political life, rather a moment where he was obliged to relatively helplessly watch the events unfold in his homeland. The new Governor of Kenya, Sir Evelyn Baring, heeded advice of his officials and declared a state of emergency; ordering the arrest of the entire KAU leadership as a means of ending the violence. Meredith writes that this move was taken by the Mau Mau activists as 'tantamount to a declaration of war. ${ }^{\text {,206 }}$ This caused the white farmers of the Rift Valley to panic, and subsequently expel a further 100,000 squatters - a move that swelled the Mau Mau's recruitment base. ${ }^{207}$ Baring's actions had only served to exacerbate the rebellion which soon escalated into open violence with the deaths of thousands of loyalist (to Britain) Africans, and subsequently tens of

\footnotetext{
${ }^{206}$ Meredith, p. 85

207 Ibid
} 
thousands of rebels and their supporters (actual figures remain heavily contested). ${ }^{208}$ The white community escaped the rebellion without such a shocking loss of life; with 32 Mau Mau related deaths. ${ }^{209}$ By October 1952 six Battalions of the British Armed Forces were called into Kenya to end the rebellion. ${ }^{210}$

Governor Baring was bent on pinning the rebellion on Kenyatta. This was likely to appease settler anxiety. Generating a conviction of Kenyatta was a complex process as for one; Kenyatta was not a Mau Mau leader, nor were there many willing witnesses or sources of evidence to corroborate such a claim. This led Baring to offer rewards for anyone willing to testify against Kenyatta; the eventual prosecuting witness received two years university education in Britain, all expenses paid, and a government job upon his return to Kenya. ${ }^{211}$ Despite having nine defence witnesses testify against the accusation, Kenyatta was convicted of being the 'mastermind behind the Mau Mau who had used his influence over the Kikuyu to persuade them in secret to murder, to burn, to commit evil atrocities, with the aim of driving all the Europeans out of Kenya.' ${ }^{212}$ Meredith includes Magistrate Ransley Thacker's concluding remarks; 'you have let loose upon this land a flood of misery and unhappiness affecting the daily lives of the races in it, including your own people. ${ }^{213}$ Kenyatta was convicted and sentenced to an isolated imprisonment in the inhospitable northern desert. The authorities then set about to try and erase public memory of Kenyatta through the destruction of his home and publically asserting that Kenyatta would never be able to return to Kikuyu land. These endeavours were unsuccessful.

\footnotetext{
${ }^{208}$ Meredith, p. 86

${ }^{209}$ Ibid

${ }^{210}$ Anderson, p. 390

${ }^{211}$ Ibid, p. 390

${ }^{212}$ Meredith, p. 87

213 Ibid
} 
Historian David Anderson notes that the events of the Mau Mau were an increasing embarrassment to even Winston Churchill's Conservative Government (elected in 1951). ${ }^{214}$ The Indian Prime-minister Jawaharlal Nehru sternly criticised the British handling of the Mau Mau on the international stage, bringing further pressure on the administration. ${ }^{215}$ Churchill was obliged to resign in 1955 due to ill health and was replaced by his ambitious lieutenant Anthony Eden. Eden oversaw entire battalions of the British Armed Services withdrawn from Kenya and also made surrender and amnesty offers to Mau Mau rebels and supporters. ${ }^{216}$ The remaining British forces were removed from the forests where they had pursued the Mau Mau fighters and in 1955 the Government lifted the ban on African political organisations. ${ }^{217}$ By 1959 Anthony Eden had lost office and was followed by Prime Minister Harold Macmillan, who was to preside over the dissolution of the British Empire. In one of his first acts as Prime Minister, Macmillan undertook a cabinet reshuffle, and replaced the Secretary of State for the Colonies with lain McLeod. Iain McLeod was easily one of the most progressive members of his cabinet, and his approach to colonial affairs attracted significant criticism from the right wing elements of British politics. Shortly after McLeod's appointment Kenya was declared no longer in a state of Emergency. ${ }^{218}$ Iain McLeod, however, had grander plans than just the cessation of hostilities. 'In 1960 while his Prime Minister was in Africa, McLeod called the various groups interested in Kenya's future to a conference at Lancaster House in London. There he made it plain that Britain intended to give African's majority rule in Kenya as soon as possible. ${ }^{219}$

\footnotetext{
${ }^{214}$ Anderson, p. 105

215 Ibid

${ }^{216}$ Ibid, pp. 392 - 393

217 Ibid.

218 Ibid.

${ }^{219}$ Murray-Brown, p. 299
} 
Michael Blundell was another key character in the search for the conclusion of racial hostilities in Kenya. Blundell had farmed in Kenya since the mid 1920's and was elected to Kenya's legislative council in 1948. He had been appointed to Minister of Agriculture in 1955 at the height of the Mau Mau Emergency. Blundell quickly saw that land was the key to resolving the Kikuyu grievances that were fuelling the violence. He therefore 'set in train a plan to demarcate and grant title to land and to develop cash crops. As the 87,000 [Mau Mau] detainees were released many went straight back to a stable farming life. ${ }^{220}$ In 1956 the Colonial Administration had allowed limited African representation on Kenya's Legislative Council; Blundell formed healthy relationships with these men and he subsequently formed the multi-racial 'New Kenya Party. ${ }^{221} \mathrm{His}$ obituary notes that he 'showed the European and Asian communities that they could live as Kenyans under African majority rule'. ${ }^{222}$ This provides more evidence of the recurring theme of the British Empire manifesting itself in myriad different ways in unique environments, and the difference in these manifestations often depending on the personalities involved.

The Colonial Administration clung tenaciously to power, despite the reality that the era of their dominance was clearly coming to an end. It was not just for the British retreating; the French were retreating (or being forced out) of their African and Asian possessions, and the Belgians out of their central African fiefdoms. The Portuguese would be obliged to give up their 'oversees provinces' of Angola and Mozambique. In this new era of decolonisation it became increasingly difficult for the British to justify absolute authoritarian rule in their African colonies. Colonial operatives still wedded to the ideas of paternalist white dominance had to attempt different tactics slow the

\footnotetext{
${ }^{220}$ Obituary of Michael Blundell, The Independent, $9^{\text {th }}$ of August, 2012

${ }^{221}$ Ibid.

${ }^{222}$ Ibid.
} 
process of decolonisation in line with the policy of the 'long apprenticeship'. In practice this meant colonial administrations attempted approaches such as the generic 'divide and rule' tactic. ${ }^{223}$ This was undertaken by allowing Africans representation only at the district level, and usually only 'loyalists' (those who had assisted the British during the Mau Mau) were allowed to participate. Arnold notes that the British sought to splinter a prospectively independent Kenya on a regional basis 'to leave behind a weak political structure, more easily manipulable from outside'. ${ }^{224}$

Kenyatta was finally released in on the $15^{\text {th }}$ of August, 1961, under the KAU threat of a renewal of violence. Arnold notes that the incumbent Governor of Kenya, Sir Patrick Renison, 'was to handle the Kenyatta question in such a way that he himself became symbolic of an almost desperate backward looking colonialism. ${ }^{225}$ Right up until the transfer of power, Governor Renison was not capable of convincing himself to come to terms with the man who was clearly central to the future of Kenya. For as long as possible, the colonial authorities deferred the transfer of power to a majority of Kenyan voters. Arnold asserts that this was in part because of a need to safeguard British interests in East Africa, but also 'a question of psychology: it was not possible to be both an effective colonial administrator and at the same time come to terms with African independence, since one was in negation of the other. ${ }^{226}$ Meredith notes that using the 'old Colonial Office criteria for self-government, British officials estimated that a minimum period of between ten and fifteen years of intensive training was needed to prepare reasonable efficient and stable modern administrations. ${ }^{, 227}$ It has been noted previously that the British institutions of colonialism were subject to

\footnotetext{
${ }^{223}$ Arnold, p. 50

${ }^{224}$ Ibid, p. 51

225 Ibid.

226 Ibid.

${ }^{227}$ Meredith, p. 91
} 
considerable inertia, and despite the inspiring rhetoric of Harold MacMillan's 'Winds of Chance Speech', colonial officials in Kenya were slow to uptake this new mood of decolonisation. In that ground shifting piece of oratory MacMillan asserted;

'The wind of change is blowing through this continent and whether we like it or not, this growth of national consciousness is a political fact. We must all accept it as a fact, and our national policies must take account of it. ${ }^{128}$

Unfortunately for the progress of indigenous leadership the settler population of Kenya was not willing to accept the growth of a Kenyan national consciousness as a political fact, and accordingly petitioned the Colonial Administration to maintain control.

Upon his release much of Kenyatta's activity had to be invested in dispelling white settler fears of the coming majority rule. He also had to allay their fears of him personally. To achieve this he made clear his disdain for the Mau Mau; hardly surprising considering it was the Mau Mau leadership's liberal use of his name to justify their actions which contributed to his near decade long imprisonment. Meredith includes a 1962 quote of Kenyatta's, aimed at the settlers. He stated; 'we are determined to have independence in peace, and we shall not allow hooligans to rule Kenya... we must have no hatred towards one another. Mau Mau was a disease which has been eradicated, and must never be remembered again. ${ }^{\prime 22}$ In 1963 , at a meeting with 300 white farmers, Kenyatta assured them;

"We want you to stay and farm well in this country. We want you to stay and co-operate with us... We must try to trust each other. We cannot go on looking backwards. We must look forward to the future. I suffered a prison and

\footnotetext{
${ }^{228}$ McMillan, Harold, 1960, in Meredith, p. 90

${ }^{229}$ Meredith, p. 90
} 
detention term, but that is out of the past, and I am not going to remember it. So let us adopt one policy of give and take'. ${ }^{230}$

Kenyatta pressed this message of forgiveness to the settlers and even went to the lengths of seeking their support for the new nationalist political organisation, the Kenyan African National Union (KANU). Arnold notes that reconciliation was also a strategic priority for Kenyatta, as he was positioning himself for independence leadership. Settlers were leaving Kenya at a rate of 700 per month, ${ }^{231}$ and with them they were taking the skills and expertise necessary for building a self-sustaining noncolonial economy in Kenya. Arnold notes that 'in 1962 80\% of Kenya's exports - worth $£ 38$ million - were produced by the settlers, and they disbursed a total of $£ 10$ million in wages. ${ }^{232}$ Kenyatta acknowledged that in order to arrest the departure of the settlers, he needed to convince them that they had an African protector in the new Kenya. He achieved this reputation through actions such as insisting on the state paying full compensation to European farmers for any farms that were taken over in the White Highlands. Arnold writes that the settlers who remained 'never had it so good as in the years following independence.' ${ }^{233}$ Kenyatta's early push for reconciliation with the settlers is perhaps evidence of his growing awareness of the 'situational array' to use Greenstein's analysis. In what was clearly an environment of significant restricting, Kenyatta's growing ability to see and understand the forces that were going to frame his future leadership - enabled him to more effectively navigate his milieu. Kenyatta understood that the settlers were critical to the economic viability of an independent Kenya, and thus located himself accordingly. Kenyatta did, however take a calculated risk here. If Burn's thesis is applied, then Kenyatta was moving

\footnotetext{
${ }^{230}$ Kenyatta, Jomo, 1963, in Arnold, p. 66

${ }^{231}$ Arnold, p. 66

232 Ibid.

233 lbid, p. 67
} 
against the mood of his general followership - the Kikuyu. This is where 'transformational leadership' was required to take place, in that Kenyatta was obliged to convince his African kin that the future of Kenya rested in reconciliation and cooperation, not further conflict and bloodshed. This accords with of Burn's theory with regard to the raising of the moral deportment of the followership beyond their basic interests, passions and grievances.

While Kenyatta was still imprisoned, two of his fellow nationalists, Tom Mboya and Oginga Odinga, had worked to set up the Kenyan African National Union Party (KANU). ${ }^{234}$ Shortly after creating the organisation, Mboya and Odinga elected Kenyatta their president 'in abstentia. ${ }^{235}$ In October 1961, following Kenyatta's release he assumed the full presidency of KANU. This was followed by his acquisition of a native seat in Kenya's Legislative Council, and his joining of the coalition government. It was at this time that the radical shift in British colonial policy was beginning to manifest itself on the ground.

Following Harold McMillan's 'Winds of Change' speech, Meredith notes that the British change in course was abrupt, and that the philosophical view was grounded in the belief that if African political progress was continually held up by the interests of white settler minorities then Britain would only face more bloodshed. ${ }^{236}$ This meant that KANU rapidly attracted the attention of all those interested in the future governance of Kenya. Murray-Brown notes that as President of KANU, Kenyatta demonstrated a lack of effectiveness as either a party leader or as a government minister. ${ }^{237}$ It was

\footnotetext{
234 'Jomo Kenyatta' in Encyclopaedia Britannica Academic Addition http://www.britannica.com/EBchecked/topic/315185/Jomo-Kenyatta (Accessed 12th August, 2012) 235 Ibid.

${ }^{236}$ Meredith, p. 90

${ }^{237}$ Murray-Brown, p. 308
} 
argued by some of his contemporaries that the long periods he had spent isolated from African politics, both in Europe and in prison, had exhausted his powers of leadership. They asserted that this coupled with his supposed drinking habits had brought him to near senility. ${ }^{238}$ KANU's strength however was not generated solely by the leadership of Kenyatta. Tom Mboya brought to the organisation a wealth of organisational ability, cultivated from decades working as a trade union organiser and Oginga Odinga brought unswerving loyalty. This was coupled with Kenyatta's natural strength at attracting huge crowds to outdoor meetings 'reminiscent of the old tribal barazas where he used his proverbs, tribal lore, and spell-binding words. ${ }^{239}$ MurrayBrown notes that Kenyatta deployed these skills to full and great effect in the lead up to the election of $1961 .^{240}$

It was these strengths which enabled KANU to sweep the polls in Kenya's first election where the majority were enfranchised. Murray-Brown notes that the unique strengths of the KANU leadership enabled them to effectively navigate the highly complex electoral arrangements bequeathed upon them by the British, especially the devolution and regionalism that the architects of the constitution had employed to weaken the independence leadership. ${ }^{241}$ On the $28^{\text {th }}$ of May 1963, Kenyatta was invited to form a government by the last Governor of Kenya, Malcolm MacDonald, having just joined his younger colleagues in a traditional victory dance on the streets of Nairobi. On the $1^{\text {st }}$ of June he became the first Prime Minister of a self-governing Kenya. Full independence was set for the following year. Murray-Brown notes that it was at this time that Kenyatta gave his country a new rallying cry; 'Harambee!, an old

\footnotetext{
238 Ibid.

239 Ibid.

240 lbid.

241 Ibid.
} 
work chant meaning pull together. ${ }^{242}$ On attaining independence Kenyatta gave what Meredith calls one of the most poignant speeches of the rush to decolonisation in Africa. In that speech Kenyatta asserted, 'we do not forget the assistance and guidance we have received through the years from the people of British stock: administrators, businessmen, farmers, missionaries, and many others. Our law, our system of government and many other aspects of our daily lives are founded on British principles and justice. ${ }^{243}$ Kenya was the thirty-fourth state in Africa to achieve independence. 'All over the world the Union Jack was coming down and Auld Lang Syne being sung, but nowhere was the scene played out with greater poignancy than in Nairobi. ${ }^{244}$

\section{$\underline{\text { The President }}$}

As early as 1964 the emergence of a 'one party state' was noticeable in Kenya. Opposition members of the Kenya African Democratic Union (KADU) had begun to cross the floor of Kenya's legislative assembly to join Kenyatta's government. Whilst this enabled Kenyatta to claim true representation of all Kenyans (rather than just his affiliated Kikuyu and Luo tribes), it also set a dangerous precedent for the future of Kenya's democracy. Arnold notes that international observers were not alarmed by the drift toward a one-party state, instead commending Kenyatta for creating an atmosphere of reconciliation, buoyancy and unity within the independent Kenya. ${ }^{245}$ Arnold writes that Kenyatta was in many ways a political conservative, and placed significant emphasis on the preservation of law and order in the new Kenya. Especially noteworthy was his determination to uphold laws around private property. ${ }^{246}$ Kenyatta

\footnotetext{
242 Murray-Brown, p. 309

${ }^{243}$ Kenyatta, 1963, in Meredith, p. 92

${ }^{244}$ Murray-Brown, p. 310

${ }^{245}$ Arnold, p. 155

${ }^{246}$ Arnold, p. 156
} 
also sought prosperity through welcoming foreign investment in Kenya. His Foreign Investments (Protection) Bill sought to legislate in favour of the flow of foreign capital into the Kenyan economy. ${ }^{247}$

Kenyatta's decision to break with other African independence leaders, favouring the capitalist path over the 'African socialism' that proved popular in the decolonisation era - would be a trade mark of Kenyatta's leadership. Murray-Brown argues that Kenyatta's leadership was relatively free of ideology, compared with many of his contemporary independence leaders across Africa. Kenyatta had sought power purely on a belief in self-government, not an ideological predisposition emanating from the west or east. This pragmatism was well accommodated within in the one-party governing structure that rapidly evolved in independent Kenya. Murray-Brown asserts 'from the moment he became Prime Minister... Kenyatta began to assert his own will in the way Kenya was run. The achievement of personal power unstopped reserves of self-confidence and authority which many had previously doubted he possessed. ${ }^{248}$

Kenyatta was quick to recognise the value of some of the colonial institutions bequeathed upon his new country, and therefore ensured the preservation of the most useful elements of the British governing structure. Institutions like the police and army were taken over completely intact, despite their previous employment against the independence movement. Kenyatta even went as far as to retain the services of European officers such as lan Henderson - the inspector who had prepared the case against him years earlier. Murray-Brown notes, 'in the same way the judiciary, civil service and Parliament continued to function according to their British models and

\footnotetext{
247 Ibid, p. 158

${ }^{248}$ Murray-Brown, p. 312
} 
with white men still in senior posts'. ${ }^{249}$ Kenyatta also sought to strongly rebuke members of the nationalist core who spoke of revenge against the institutions of the colonial era. Members of the rebel columns in the forests refusing to join in the new era of reconciliation, and accept Kenyatta's resettlement schemes were quickly brought to heel by Kenyatta's new state.

Murray-Brown notes that white families who only several months before had treated Kenyatta and KANU with the highest suspicion now took the attitude of 'everything will be all right so long as the old man is there. ${ }^{250}$ Settler families were now taking up Kenyan citizenship - demonstrating a willingness to participate and contribute to Kenyatta's new Kenya. Kenyatta was strategically positioning himself, as Greenstein's theory would observe, as a reconciler and unifier within the dynamic context. This would see him located to have great historical impact. Kenyatta's acknowledgement of the setter economy's critical importance to the overall welfare of his government demonstrated remarkable discernment which some of his contemporary African leaders lacked. Kenyatta's valuing and preservation of some of the colonial era institutions enabled his new state to capitalise on the accumulated expertise of the old regime's civil service. Meredith notes that this expertise was in short supply within the African community. 'The speed of change meant that colonies in East and Central Africa advanced toward independence with a minimum of trained local man power. [For example] Kenya's first African lawyer did not begin to practise his profession until 1956. ${ }^{251}$ Nevertheless this was still an accommodation of the colonial system. As Kenyatta settled into the presidency, he increasingly did not conform to Burns' model of transformational leadership

\footnotetext{
${ }^{249}$ Murray-Brown, p. 312

${ }^{250}$ Ibid, p. 313

${ }^{251}$ Meredith, p. 91
} 
Kenyatta may have taken his accommodation of the old order too far when he scrapped the regionalised independence constitution and reverted to a centralised administrative system. This system was synonymous with that which existed under the old colonial governors. ${ }^{252}$ This represented the drift toward a one-party state. Historian John Cartwright's theory holds that this may have seemed 'obvious' to Kenyatta as; 'a wide range of political, social and economic forces encouraged the new rulers to eliminate rivals and to close off channels to direct challenges to their position.' ${ }^{253}$ Cartwright asserts that this was in part because of the ambiguities of the political values instilled by colonial system. These ambiguities 'facilitated leaders justifying increasingly authoritarian practices as being for the good of their people. ${ }^{254}$ Such ambiguities are almost certainly references to colonial paternalism, and paternalistic justifications for the authoritarian nature of colonial governance. The paternalistic mould suited Kenyatta's leadership style remarkably well. In 1964, Kenya became a Republic within the Commonwealth, with Kenyatta assuming the role as President. Murray-Brown asserts that Kenyatta was 'stepping into a role in which he had watched many a plummed-hatted governor fill in the past. ${ }^{255}$ Kenyatta began to enjoy a massive level of authority which would frame much of his presidency. Cartwright asserts this was a typical situation in the context of African independence leadership, where the new leaders soon found themselves defending the authoritarian regimes which they had fought so earnestly against during their independence struggles.

Despite the continuity of authoritarian paternalism of Kenyatta's political orientation, elements of liberal ideology can be tracked from very early on his leadership. Kenyatta

252 Murray-Brown, p. 313

${ }^{253}$ Cartwright, p. 54

254 Ibid.

${ }^{255}$ Murray-Brown, p. 313 
was vigorous in his promotion of grass-roots 'self-help' organisations that were responsible for the construction of educational, health services and water provision. Meredith articulates Kenyatta's theoretical justification for this through a phrase he frequently broadcast to his audiences, 'God... helps those who help themselves.'256 Guy Arnold buttresses this claim, asserting that Kenyatta invited those with the power 'to use it for their own advancement... [and showed contempt] for anyone not concerned to better himself. ${ }^{257}$ Perhaps this dualism in Kenyatta's leadership, between authoritarian paternalism and a belief in encouraging the industriousness of the individual can be traced back to his Scottish missionary education - as this dualism was well observable in the culture of the protestant missionaries he was educated by. Here the scholar may be able to observe a distinctive impact of the British methods of colonial development on the nature of an independence leadership case. The paternalism was also potentially attributable to traditional forms of Kikuyu leadership, though the synthesis with forms of western liberalism was unusual in the African context.

Kenyatta's gradualism and desire to retain the good faith of the settler population was well demonstrated with his early land distribution policies. Using British funds, Kenyatta's government oversaw the diffusion of the land hunger that had fuelled the Mau Mau through gradually buying out sections of the former White Highlands. 'White farmers were bought out both by smallholders and by other African owners. ${ }^{258}$ This gradualism starkly contrasts (and is vindicated when compared with) the transfer of land that occurred in Zimbabwe decades later. According to Meredith this was followed by a remarkable increase in agricultural incomes; 'between 1958 and 1968

\footnotetext{
${ }^{256}$ Meredith, p. 265

${ }^{257}$ Arnold, p. 190

258 Ibid.
} 
the gross farm revenues of small-holders grew by $435 \% .{ }^{259}$ By the 1970 s Kenya was enjoying a growth rate in the agricultural sector of $5.4 \% .{ }^{260}$ Kenyatta's reconciliatory approach and his gradualism worked to great effect. Within the context of the sustainable economic growth, buttressed by Kenyatta's steering Kenya away from the redistributive socialism that was to flourish elsewhere in Africa, the international community was willing to turn a blind eye to the autocracy and dominance that Kenyatta increasingly exercised. The model racial reconciliation that was occurring between settler and African further justified this approach. As far as the theory is concerned, Greenstein's analysis explains Kenyatta's success. In the environment of restructuring, he managed the pace and direction of the restructure in such a way that he attained a strategic location at the apex of the new political structures. Kenyatta also began to conform to Burns' mould of transactional leadership - whereby the relationship between him and his followers was based not so much on mutual stimulation, but on the exchange of wealth for power between the emergent new elites and Kenyatta.

The post-independence security that Kenyatta was offering was also attracting flocks of foreign tourists to Kenya's spectacular wildlife parks and coastal resorts. These tourists further supported Kenya's impressive post-independence economic boom. Nairobi's skyline was transformed into that which resembled many western capitals; containing sky-scraping hotels and office blocks. This prosperity translated into an average increase of $6 \%$ in gross domestic product each year in the 1960 s, and $6.5 \%$ in the 1970 s. ${ }^{261}$ Coupled with the improvements in the economic performance of Kenya, the population boomed. In 1962 it stood at around 8 million, by 1978 it had almost

\footnotetext{
${ }^{259}$ Arnold, p. 190

260 Ibid

${ }^{261}$ Arnold, p. 266
} 
doubled to 15 million. Kenyatta's gradualist and capitalist strategy was being vindicated as far as outside observers were concerned.

Kenyatta's capitalist strategy was also generating significant disparities within the African population; disparities that were disguised by the symbols of a roaring economy. While African elites grew richer and more powerful as a consequence of land transfers and the attainment of senior government appointments, progress was slower, if not backward, for the millions of Kenyans who did not enjoy land-title or government connections. Eventually political pressures began to build up as more Kenyan's wanted a share of the substantial economic gains the top tier of the population were enjoying. In Kenyatta and the Organisation of KANU, Kenneth Good notes that the radicals within the governing KANU party who took up the cause of the masses who were not enjoying the independence miracle, were rapidly isolated and excluded by Kenyatta's inner circle. ${ }^{262}$

In 1965 Kenyatta radically reduced the power of 'backbench' Members of the National Assembly. Earlier in June 1964 some KANU backbenchers broke the government policy of silence on the idea of an East African Federation and demanded that Kenyatta take steps to federate with bordering states. Kenyatta reacted fiercely to this dissent and decreed that all MP's 'must obtain a licence from the Administration before they could speak at a public gathering, even in their own constituencies. ${ }^{263}$ The President's grip on the party and the politics of Kenya was now vice-like in character. In 1965 Mwai Kibaki, ${ }^{264}$ warned of an emerging African elite around Kenyatta and his family, He went to assert that if Kenyan society continued without change, then in five years there

\footnotetext{
${ }^{262}$ Good, Kenneth, 'Kenyatta and the Organisation of KANU', in Canadian Journal of African Studies, Volume 2, No.2, 1968, pp. 115-136

${ }^{263}$ Arnold, p. 189

${ }^{264}$ President of Kenya since 2002
} 
would be a new social class governing Kenya with the same vested interests in control as the previous colonial administration. ${ }^{265}$

A former Mau Mau leader and prison companion of Kenyatta, Bildad Kaggia publically challenged Kenyatta's land policies only to suffer a savage and public rebuke. Kaggia criticised the government for allowing land to pass into large individual titles for privileged Africans, allowing them to amass substantial holdings. 'He warned of the dangers of letting a new class of African landholders replace the white settlers while landless Africans were struggling to survive. ${ }^{266}$ Kenyatta's response was to publically humiliate Kaggia, while they were speaking from the same platform at an event. ${ }^{267}$ Kenyatta denigrated Kaggia for his distinctive lack of achievement in the new Kenya. This became typical of Kenyatta, Meredith writes that "he was ruthless in dealing with any challenge to his authority. ${ }^{268}$

Oginga Odinga, the prominent Luo who had earned himself the chiefly title of Ker which is loosely synonymous with being a king, provided the first real threat to Kenyatta's dominance of Kenyan politics. Kenyatta had appointing Odinga as his VicePresident after independence, a gesture symbolising the Kikuyu-Luo partnership at the head of the KANU party. In 1966 he split from the governing party to form his own minority party, the Kenya People's Union (KPU). Odinga advocated for a free distribution of white-owned land and a programme of nationalisation of foreign owned enterprises in Kenya. In regard to foreign policy, Odinga wanted a shift from western allegiances to new ties with the Eastern bloc. ${ }^{269}$ By 1968 the relationship between the

\footnotetext{
${ }^{265}$ Arnold, p. 190

${ }^{266}$ Meredith, p. 266

${ }^{267}$ Arnold, p. 190

268 Ibid.

${ }^{269}$ Meredith, p. 266
} 
government and the KPU was bitter. Kenyatta had already centralised control of the civil service on the Office of the President. The forty-one District Commissioners (another colonial hangover preserved in the post-independence era), reported directly to the President rather than the Parliament. Supporters of Kenyatta's regime asked why not simply outlaw the KPU and officialise Kenya as a one-party state. ${ }^{270}$ Kenyatta opted to accuse Odinga of communist affiliations, asserting 'some people try deliberately to exploit the colonial hangover for their own interest, to serve some external force... to us, communism is as bad as imperialism. ${ }^{271}$ Meredith writes that Kenyatta also sought to brand his opponents as subversive and tribalistic. ${ }^{272}$ By 1969 his patience with opposition ran out. He had his former nationalist comrade arrested and his party outlawed. This move all but formalised Kenya as a one-party state, with Kenyatta and his inner circle holding complete dominance of the policy process.

According to James McGregor Burns, leadership is a dynamic relationship between leader and follower. Burns asserts that the naked wielding of power is not leadership, and that the leader and the tyrant are polar opposites. The application of Greenstein's theory holds that Kenyatta had located himself in such a position within the political milieu that he could act with near autonomy. From a strictly western liberal perspective the researcher could discern that Kenyatta was on a direct path to dictatorship, which is not leadership according to Burns. The keystone here, however, is Abraham Maslow's theoretical contribution, as detailed in the previous chapter. Historians such as Murray-Brown, Meredith and Arnold all agree that the trademarks of Kenyatta's leadership were law, order and stability. The pursuit of these created the pre-conditions for remarkable economic growth. Within this environment, enough of

\footnotetext{
${ }^{270}$ Arnold, p. 190

${ }^{271}$ Kenyatta, Jomo, 1965, in Meredith, p. 266

272 Meredith, p. 266
} 
the followership - that is the Kenyan citizenry, enjoyed unprecedented satisfaction of Maslow's needs; that is their physiological needs were by and large well satisfied, life in Kenya was safe, and a significant proportion of the population were enjoying the satisfaction of their esteem and self-actualisation needs within a prosperous Kenya. 'With government assistance, an expanding African middle class grasped opportunities in the civil service, agriculture, commerce and industry. ${ }^{, 273}$

With the Cold War dominating international relations during Kenyatta's tenure, his decision to pursue a western-capitalist road attracted significant endorsements from the west, and foreign direct investment (FDI). In a 2005 report on investment in Kenya the United Nations Development Program notes that 'FDI grew steadily throughout the 1970s as Kenya was the prime choice for foreign investors seeking to establish a presence in Eastern and Southern Africa. ${ }^{274}$ The report holds that the relatively high level of development, good infrastructure, market size, growth and openness to FDI at a time when other countries in the region had relatively closed regimes all contributed to [overseas investors] choosing Kenya as their regional hub. ${ }^{275}$ Interestingly, this report notes the post-Kenyatta decline in all of the above was a consequence of the failings of the following regimes. Kenyatta's leadership, though authoritarian and paternalistic, created an environment where enough aspirational Kenyans could share in the prosperity. A consensus emerged among the followership that 'old mzee' provided stability and security, whilst attracting prosperity and opportunity. This made up a large body of the political currency on which Kenyatta traded with the followership. This does not conform to Burns' theory of the transformational leader.

\footnotetext{
${ }^{273}$ Meredith, p. 265

${ }^{274}$ United Nations Development Program, Investment Policy Review - Kenya, 2005, http://mirror.undp.org/kenya/IPC\%20-FDI.pdf (Accessed $20^{\text {th }}$ August 2012) 275 Ibid.
} 
The Kenyatta experience displayed some elements of transformational leadership such as zeal for reconciliation with the landowning settlers, though by and large Kenyatta was not a transformational leader. He instead opted for a 'particular brand of quiet stability' that Arnold writes was the hallmark of Kenyatta's reign. ${ }^{276}$ This was a political exchange with the followership and thus conforms to the transactional model.

In the early 1970's Kenyatta's leadership experienced a legitimate and populist political threat from his former private secretary Josiah Mwangi Kariuki. The stability and prosperity that Kenyatta used to legitimise his centralist rule was not being enjoyed by all Kenyans. The numbers of Kenyan's not capitalising on the post-independence prosperity were swelling by the mid-1970s. J.M. Kariuki emerged as a champion of Kenya's poor and landless. He openly set his goal of becoming Kenyatta's successor. Considering his Kikuyu and Mau Mau background, coupled with his populist rhetoric against the new African elite - his goal seemed achievable. Meredith includes one of his more famous populist rallying calls; that 'a stable social order cannot be built on the poverty of millions. Frustrations born of poverty breed turmoil and violence. ${ }^{277}$ Meredith writes that he possessed an 'unerring popular touch and he skilfully exploited the groundswell of discontent that was building up over the greed and corruption clearly evident at the top of Kenyan society. ${ }^{278}$ It was true that senior government officials and members of Kenyatta's family and inner circle were doing a little too well out of the good economic times - in proportion to the majority of Kenyans. Whilst the system was stable, rot was beginning to set in at the top of the regime.

\footnotetext{
${ }^{276}$ Arnold, p. 191

${ }^{277}$ Kariuku, J.M., in Meredith, p. 267

${ }^{278}$ Meredith, p. 267
} 
Kariuki never dared directly criticise Kenyatta himself. This was because Kenyatta was more or less untouchable in the eyes of the Kenyan populous. Kariuki and his allies instead levelled their critique of the government upon members of Kenyatta's inner circle, who were mostly Kenyatta's family members and were thus referred to as the royal family. ${ }^{279}$ This group aroused significant resentment as they publically enjoyed the presidential life-style yet held not even remotely the same level of dignity, prestige and respect that Jomo had earned from the Kenyan people. Kariuki therefore focused his attention on two members of the 'royal family' who were easy examples of the indulgence going on at the top. Kenyatta's young wife, Ngina and his daughter Margaret, the Mayor of Nairobi were easy targets as they operated their business empires ruthlessly and used their close links with the President for substantial personal gain. ${ }^{280}$ By this time Jomo's age was becoming evident, and as Meredith writes, he was showing less and less interest in the business of government. ${ }^{281}$ This enabled members of the 'royal family' to operate relatively unchecked by old mzee. Ngina Kenyatta became one of the richest individuals in Kenya with interests in agriculture, tourism and property. Meredith also notes that both family members were involved in the Ivory trade, and that the high level corruption that suited their operations cost Kenya half of its elephant population; with the deaths of at least 70,000 elephants. ${ }^{282}$ Kariuki was always careful to never mention names when he levelled his critique of the existing state of affairs, though Meredith notes it was clear who he was referring to. Quotes such as 'we do not want a Kenya of ten millionaires and ten million beggars, or 'we are being carried away by selfishness and greed' were perceived as a direct threat

\footnotetext{
${ }^{279}$ Meredith, p. 267

280 Ibid.

${ }^{281}$ Ibid, p. 266

282 Ibid, p. 267
} 
by members of the Kenyatta inner circle. ${ }^{283}$ In March 1975 Karuiki's mutilated body was discovered, dumped in the hills outside Nairobi. 'Subsequent investigations implicated members of Kenyatta's inner circle. ${ }^{284}$

The 'inner circle' was not held to account for the death of Kariuki, and as Kenyatta's political, and biological life waned they essentially took the reins. He spent the last three years of his life governing through what almost resembled a feudal court of loyal ministers and officials. He spent his time lecturing any visitors on the finer points of Christian theology and recounting stories about the 'dour Scottish missionaries who so influenced his childhood. ${ }^{285}$ His gentle decline consisted of pottering around his two farms and spending his evenings watching tribal dancers. On the $23^{\text {rd }}$ of August 1978, Kenyatta's presidency concluded with his death by natural causes ensuing from old age. This was followed by a state funeral, a period of national mourning and the enduring presidency of Daniel arap Moi.

\section{Theoretical Questions of Kenyatta's Leadership}

1. How strategically well placed was Jomo Kenyatta to affect meaningful political change in Kenya? (Greenstein)

Through a series of evolutions in the practice of his leadership, Jomo Kenyatta became relatively adept in locating himself in a position within his political context to significantly impact upon the progress of history in Kenya. The account of Kenyatta's political career above does, however, demonstrate that Kenyatta's strategic location within the environment was mostly dominated by forces beyond his control. An example of this was Kenyatta's Scottish missionary education, and how it enabled him

\footnotetext{
${ }^{283}$ Meredith, p. 268

284 lbid.

285 Ibid.
} 
to join an emergent and politicised urban African elite. The KCA's favouring of Kenyatta as their representative in London also proved to be a critical force in establishing Kenyatta's location within the subsequent political context. As noted earlier, Kenyatta also demonstrated ineptitude with regard to his strategic location during the Mau Mau Emergency - and spent nearly a decade in prison because of it. On this matter there is a school of thought that holds Kenyatta's strategic location was enhanced because of his prison time, as several popular independence leaders had undergone a 'prison internship' before leadership, though Kenyatta's nine years in a northern desert during one of the most significant upheavals in Kenyan history hardly constitutes an internship.

Once in power, however, Kenyatta's management of his strategic placement was legendary. He presented himself to the outside world as a stable and secure leader not affiliated to radical causes of African socialism (despite his Moscow training), and encouraged his settler population to remain in Kenya, and consequently more foreign investment to flow in. This created the economic growth and prosperity that he could use to justify his increasingly authoritarian governing practices. These practices further entrenched his strategic location at the pinnacle of Kenyan politics. This saw him well placed to affect meaningful political change and significantly impact upon historical outcomes, right up until the decline in his health during the 1970s.

2. How and to what extent did the psychological predispositions of the 'followership' in Kenya (at different times and phases) enable or disable the Kenyatta's ability lead, and therefore affect historical outcomes? (Burns, Maslow) 
Kenyatta was remarkably successful in riding a groundswell of popular discontent to significant leadership success. In terms of Kenyatta's own tribe, the Kikuyu, the land policies of the colonial government delivered Kenyatta the political activating issue that he needed to mobilise against the colonial authorities. The popular discontent among the African majority gave Kenyatta's rhetoric of liberation significant resonance which further boosted his popularity and ascendency within African politics. In the lead up to the Mau Mau, however, the psychological predispositions of elements within the followership became too intense and radical for Kenyatta to have meaningful interactions, let alone leadership - and therefore disabled his ability to lead. Once the Mau Mau Emergency had calmed, and the British government had made clear assurances to the African population of majority government - the psychological predispositions of the followership were more malleable, and thus Kenyatta was able to lead again. The readiness of significant portions of the followership to accept Kenyatta's authoritarian paternalism was also critical to the success of his leadership in the independence era. The stability and prosperity that Kenyatta offered the followership (including the settler population) attracted significant loyalty from the followership which in turn generated a psychological predisposition toward supporting him - even when genuine cracks began to appear in his administration toward the end of his life.

3. What were the other forces that made up the 'situational array' in Kenya, and how stable or unstable were they? (Greenstein)

The 'situational array' fluctuated widely in terms of stability throughout Kenyatta's life. When Kenyatta was born, the colonial authorities governed with relative ease generating a period of reasonable stability. It was at this time that the African 
liberation cause was in its infancy, and many of its leaders untested. In the interwar period however, between 1918 and 1939, the forces of African nationalism had begun to ferment which significantly increased the potential for a major environmental restructure, and therefore an unstable political/situational array. The outbreak of the Second World War briefly arrested to process of change but in 1945 the agents had begun to mobilise. This coincided with a series of native policy blunders by the colonial authorities in Kenya, and some poor choices of appointments to the role of Governor. This contributed to the significant instability within the situational array; instability that manifested itself in what Kenyatta foresaw as a 'dangerous explosion' or more commonly referred to as the Mau Mau Emergency. Following the incredible situational instability of the Mau Mau was a period of stability compared to the previous crisis, though still unstable enough for Kenyatta's leadership to affect genuine change. This was a period characterised by the British retreat from Africa. The orderly nature of British decolonisation in the 1960s meant that while the situational environment around Kenyatta was restructuring itself, it was doing so in an orderly way (in contrast to the neighbouring Belgian Congo for example). ${ }^{286}$ This created an ideally suited environment for Kenyatta's particular style of leadership; leadership that emphasised the value of gradualism and consistency.

4. Did Jomo Kenyatta possess the peculiar strengths required to engage the 'followership' and direct them toward a meaningful goal and thus manipulate the situational array - or was the situational array too oppressive for even the most skilful political actor to manipulate? (Greenstein, Burns, Maslow)

${ }^{286}$ See Meredith, pp. $93-116$ 
Kenyatta's leadership experience was evolutionary. At the time of the Mau Mau, for example, Kenyatta did not possess the peculiar strengths required to manipulate the highly unstable situational array or guide the followership - and was left alienated and vulnerable. In the post Mau Mau era, Kenyatta's peculiar strengths were tailored to the political context. He held the skills to capture the respect and adoration of the bulk of the African community, and his time in London had equipped him with all of the skills necessary to negotiate the eventual handover of power from Britain. Kenyatta had the capacity for overlaying his political messages to the citizenry with traditional folk lore and sayings, something which buttressed the perception of him as both intune with the culture of his followers, yet was also completely capable of their effective representation on the international stage. The success of this strategy was demonstrated by the trust he was accorded by his people, and their allowing him to centralise political control and power on his office and making Kenya a one party state.

5. To what extent was the British method of colonial development and management responsible for the answers to the above questions?

The British method of colonial development and management framed Kenyatta's presidency. Kenyatta's Scottish missionary education, for example, set so much of the trajectory of his life that in his final years it was the lessons he had learned from his dour instructors that he would recount to any visitors. As noted above, the dualism in Kenyatta's leadership practice between authoritarian paternalism and strong strands of liberal thought with regard to self-advancement can be traced to the culture of the Scottish missionaries. This was a consistent and central element of British colonialism across the world. 
The British development of Kenya's agricultural economy as the primary source of revenue for the colony impacted Kenyatta's leadership in a range of ways. The highland clearances and development of large productive settler-run ranches infuriated the Kikuyu and were one of the leading causes of popular discontent against the British that climaxed with the Mau Mau. In the less radical pre and post Mau Mau context, Kenyatta was successful in using this discontent to frame his messages and thus catapult himself to the forefront of African politics in Kenya. In Burns' language, Kenyatta was able to connect with the discontent among the followership around issues of land, thus building a relationship and establishing a dynamic leadership interaction. Influencing Kenyatta's leadership from a different angle, in the postindependence era, the agricultural economy that the British had built up was one of the critical sources of prosperity that enabled Kenyatta's government take credit for the economic success of the chosen strategies.

The political system the British developed in Kenya, and the revised version of that they bequeathed Kenyatta had enough internal contradictions that he could easily manipulate it and centralise great power upon himself. As mentioned earlier the British attempted to give Kenya a fractious and complicated constitution so as to disperse power. Kenyatta's comprehensive sweep of the polls and initial absorption of alternative political parties made these efforts redundant and enabled him to develop the one-party state as he so pleased. The British had envisaged a long apprenticeship for the self-government of their colonies, however, by the end of the 1950's it was clear to London policy makers that it was expedient to make it a short apprenticeship instead. This was to avoid another Mau Mau. The nature of the British governing apparatus prior to independence also played a significant part in influencing Kenyatta's 
leadership. Power in the colonial government was primarily vested in one office - that of the governor. Beneath the governor was a network of district commissioners and officials. Kenyatta never significantly changed this system; rather it appears he sought to emulate it. He exercised much the same level of power and autonomy as the former governors, and appointed a network of loyal district officials to carry out his administrations' bidding in much the same way as the old system had. In some ways it can argued that Kenyatta's brand of gradualism was more a form of colonial inertia. This experience in gradualism or inertia was not shared across Kenya's southern border, beyond Mt Kilimanjaro in Tanzania. 


\section{Chapter Three - Julius Nyerere}

In December 1961 representatives of the British Government, flew into Dar es Salaam, the capital of then British Tanganyika Territory, ${ }^{287}$ to formalise that country's independence. Weeks earlier, when speaking in support of the Tanganyikan Independence Bill as it passed through the British House of Lords, the Minister of State for Colonial Affairs, the Earl of Perth, asserted;

'This is, as I say, most satisfactory; and the main credit for it goes to the Prime Minister of Tanganyika, Mr. Julius Nyerere. No doubt many of your Lordships know him. He is a man of great wisdom and charm, very skilful in negotiation and, perhaps I should say, moderate in his presentation of his demands. The result of all that, and the peaceful way in which the country has been led to its present state, has been a natural one-namely, that one is predisposed to try to help him forward on the road that he has set. I think it is just because of the moderation and wisdom with which he has handled these affairs that we find that Tanganyika is the first of the East African territories to reach independence. Perhaps there is some moral in this, and, if there is, it may be that it will not be lost on others in the territories in that area. ${ }^{288}$

Thirty-Eight years later Tanzania saw what British newspaper 'The Independent' called 'the biggest outpouring of collective grief [the country] had ever seen. ${ }^{289}$ The reporter described what he saw as Tanzania throwing itself 'into a 48-hour non-stop orgy of tears for Baba wa Taifa - the father of the nation - Julius Nyerere' ${ }^{290}$ Nyerere had died from leukaemia a week earlier. Between these two events, Tanganyika or Tanzania as it has been known since 1964, experienced one of the most significant examples of transformational leadership Africa has ever known. Nyerere took a patently nonideological, non-politicised and non-radical citizenry on an experimental path that was at times solely determined by his intellectual analysis of the political context. Meredith

\footnotetext{
287 'Tanganyika' in Encyclopaedia Britannica Academic Edition http://www.britannica.com/EBchecked/topic/582427/Tanganyika (Accessed 27th August, 2012)

${ }^{288}$ House of Lords Debates, Tanganyika Independence Bill, Second Reading, Volume $235,16^{\text {th }}$ November, 1961

${ }^{289}$ Smith, Alex Duval, 'Tanzania Weeps for Father of the Nation' in The Independent, $20^{\text {th }}$ October, 1999 290 Ibid.
} 
asserted 'Nyerere took on the drive for socialism virtually single-handedly. There was no inner group around him committed to socialism; no body of thinking within the ruling party; no working-class agitation; no militant peasantry; no popular expectation of radical change. It was Nyerere's own aspirations, his own ideology that determined government policy. ${ }^{291}$ At times this held catastrophic consequences for the citizenry. When Nyerere passed in 1999, however, the affection that the population displayed for Nyerere substantially outmatched the memory and political legacies of failed Maoist-collectivised agriculture, a heinously swollen and inefficient bureaucracy, economic collapse or political repression. To have elicited a '48-hour non-stop orgy of tears', or to have seen the normally crowded streets of Dar es Salaam emptied while even the hawkers and pickpockets paid tribute to their former president, ${ }^{292}$ one can discern the extent of Nyerere's dynamic leadership impact upon the hearts and minds of the followership.

Julius Kambarage Nyerere was born in March 1922, in Butiama, in the north of the then British Tanganyika Territory. Butiama was in many ways a backwater within a backwater; Tanganyika was considered by the British as a poor possession in East Africa when compared with the wealth of Kenya and Uganda. ${ }^{293}$ Nyerere was born under British colonial governance. The British administration in Tanganyika, however, was also in its infancy. British rule had only been in place since the end of World War I, arising from the acquisition of the territory from the vanquished German Empire. Nyerere was born into a chiefly family, his father the leader of the small Zanaki ethnic group. His father was a staunch polygamist and upholder of tradition and custom. Nyerere spent his childhood herding cattle in his father's remote fiefdom. At the age of

\footnotetext{
${ }^{291}$ Meredith, p. 250

${ }^{292}$ Smith, Alex Duval, 'Tanzania Weeps for Father of the Nation' in The Independent, 20 ${ }^{\text {th }}$ October, 1999

${ }^{293}$ Cartwright, p. 156
} 
twelve he was enrolled in Catholic missionary education, provided by the Musoma Native Authority School. ${ }^{294}$ The instruction Nyerere received at Musoma induced Nyerere's lifelong commitment and interest in Roman Catholicism. Following his initial instruction at Musoma, Nyerere, having demonstrated a measure of intellectual capacity, was enrolled in elementary education at Tabora in the Western Province of Tanganyika. This training was also provided by the Catholic missionaries, further buttressing Nyerere's commitment to the Roman Catholic Church; he was baptised pending his father's death in $1942 .{ }^{295}$ Contemporaries of Nyerere at Tabora remembered his intense commitment to his studies, and his uniquely high ambition as well as levels of competitiveness. ${ }^{296}$ In 1943, courtesy of a relatively generous scholarship, Nyerere was able to further his education at Makerere College in Kampala, Uganda. ${ }^{297}$

\section{Nyerere's awakening and the British strategy for Tanganyika}

At the time that Nyerere headed north for his academic awakening in Uganda, the British approach to the colonial governance of Tanganyika was being hotly contested between London colonial policy makers, and the colonial establishment in East Africa. In The Critical Phase in Tanzania 1945 - 1968, author Cranford Pratt asserts; 'before the [British] government began vigorously to pursue multiracialism in 1949, there was in fact little that could be called a political strategy in Tanganyika. ${ }^{298}$ There was a political consensus among the colonial administrators on the ground in Tanganyika that they knew what was best for the country and that they enjoyed the cooperation

\footnotetext{
${ }^{294}$ Assensoh, p. 125

295 Ibid.

${ }^{296}$ Smith, William Edgett, Nyerere of Tanzania, Harare, Zimbabwe, 1981, p. 45

${ }^{297}$ Mwakikagile, Godfrey, Tanzania Under Mwalimu Nyerere, Reflections on an African Statesman, California, 2004, p. 21

${ }^{298}$ Pratt, Cranford, The Critical Phase in Tanzania, 1945 - 1968, Cambridge, 1976, p. 13
} 
of the Tanganyikan population through the network of local native authorities. Pratt notes that there was little speculation in East Africa about an eventually independent Tanganyika. In London however, there was significant speculation on the future of British administration in Africa. This culminated a report by Lord Hailey entitled Native Administration and Political Development in British Tropical Africa. Pratt notes that the report was 'perceptive and liberal' for its time and outlined the inevitably of the emergence of African nationalism as a powerful force throughout the British possessions. The report called for a new and comprehensive political strategy from the colonial office. ${ }^{299}$ Lord Hailey articulated the expediency of a new strategy in the following terms;

'There are forces both at home and in the dependencies which will exert increasing pressure for the extension of political institutions making for selfgovernment, and the fuller association of Africans in them. The strength of this pressure is likely to be largely enhanced as a result of the war [WWII]. Unless we have a clear view of the constitutional form in which self-government is to be expressed, the answer to this pressure will be ill-coordinated, and may lead to the adoption of measures which we may afterwards wish to recall. ${ }^{\prime 300}$

Cranford Pratt includes a quote from the British Secretary of State Arthur CreechJones, buttressing Lord Hailey's point;

'The rate of political progress cannot be regulated according to a prearranged plan; the pace over the next generation will be rapid, under the stimulus of our own development programs, of internal pressure from the people themselves, and a world opinion expressed through the growing international interest in the progress of colonial peoples. ${ }^{301}$

The strategy that members of Hailey's school were arguing for had two central propositions; they believed in the rapid advancement of Africans within the civil service and more importantly the 'elite corps', and they argued for a significant

\footnotetext{
${ }^{299}$ Pratt, p 14

${ }^{300}$ Lord Hailey, Native Administration and Political Development in British Tropical Africa, London, 1942, p. 50

${ }^{301}$ Secretary of State for the Colonies, Arthur Creech-Jones, Dispatch of $25^{\text {th }}$ of February, 1947, paragraph 4 in Pratt, p. 14
} 
increase in the elected representation of Africans on the Legislative and Executive Councils that governed the dependencies. ${ }^{302}$ The intention of these propositions was to attract the support and cooperation of the growing numbers of educated and politically conscious Africans 'for a final and extended period of preparation for internal self-government and independence.' ${ }^{303}$ This strategy would see the replacement of local native authorities with democratic local government; this form of local democracy would be the training ground for African leaders prior to being granted further representation and political power. ${ }^{304}$ It was hoped the proposed new local government systems would inculcate the 'appropriate political values and [provide] the voter and the politician with valuable experience in the operation of democratic institutions. ${ }^{305}$ The proponents of this strategy believed that after the eventual independence, this constitutional system would lead to a system whereby these local institutions would form an electoral college- linking the future national assembly with the masses in such a way as to avoid any tendencies toward authoritarian rule. ${ }^{306}$

The enlightened virtues of the proposed strategy were lost on the East African Governors. This highlights the disjunction between the liberal philosophies of the London policy makers and the conservatism of the colonial administrators. Pratt notes that the strategy of gradual enfranchisement and the participation of Africans in colonial management were rejected by the colonial establishment in Africa, as were the principles and assumptions that underlined the approach. ${ }^{307}$ The most emphatic

\footnotetext{
${ }^{302}$ Pratt, p. 15

303 Ibid

304 Ibid

305 Ibid

306 Ibid

307 Ibid
} 
rejection came from the Governor of Kenya, Sir Phillip Mitchell. Pratt asserts that his response to the strategy was 'verbose, racist and unrepentantly imperialistic.' ${ }^{308}$ Mitchell believed that the foreseeable future of African political leadership lay with men like himself, who had taken on the 'white man's burden' to develop and civilise the tribes of Africa until they were unmistakably western European in orientation - at which point they would be fit for participation in their own affairs of government. ${ }^{309}$ Whilst the Acting Governor of Tanganyika, Sir William Battershill was not as outspoken as his northern counterpart, he indicated in similar dispatches back to the colonial office that he was in agreement with Mitchell with regard to any new strategy involving the advancement of Africans within the colonial administration. Pratt notes that Battershill's dispatch projected a level of 'lethargic prejudice.'310

The government of Tanganyika was strategic in that it claimed there was no colour bar to entry to the administrative service, however it made careful arrangements to ensure African's were never appointed. This meant that the colonial authorities could both claim they were progressive and supportive of the Colonial Office, yet could also maintain the status quo. Sir Edward Twining, who was appointed Governor of Tanganyika in 1950, justified the approach in the following statement;

'Progress is being made but before the indigenous people as a whole can assume any responsibilities in the sphere of central government, the local government system now being built up on the foundations of the native administrations must be fully and firmly established. Only thus can the great mass of the people be assured of true representation in the counsels of government. Critics may suggest that this envisages too slow a rate of progress but those responsible for carrying out the policy in Tanganyika have no doubt that the future will bear witness to its soundness. The truth is that there is no

\footnotetext{
${ }^{308}$ Pratt, p. 15

${ }^{309}$ Ibid, p. 17

310 Ibid.
} 
safe shortcut to the establishment of full democratic government among Bantu peoples. $^{\text {311 }}$

This meant that the local government reform strategy, which was intended to speed up the inclusion of Africans in the political process, was turned into a rationale for delaying the political advancement of indigenous peoples. ${ }^{312}$ Pratt notes that the Tanganyikan government were anticipating an extensive period of colonial rule, and thus prepared their institutions accordingly. They saw no need for any 'Africanisation' of the civil service, nor did they have any confidence in the small but growing numbers of educated Africans. ${ }^{313}$ The strategy of including Africans in the business of government was intended to limit the potential for authoritarianism in the event of African self-government. This strategy was deferred by the colonial administrators, to the point that it was redundant. It would be an interesting counterfactual study to analyse any potential post-independence leadership outcomes that may have occurred had the strategy been implemented in its original form. Nevertheless, it was not implemented as a result of the institutional inertia that permeated throughout the East African colonial service. This inertia was hardened by the reality that the rank and file colonial staff believed that African participation in the management of their own affairs ran counter to their various offices' raison d'etre. Thus African political progress in the post-war era was slow, and the emerging educated and politically conscious class of Tanganyikans became frustrated.

At Makerere University, Julius Nyerere gained a reputation as a star debater and a gifted student. He is remembered to have introduced international affairs into his discussions at the university, demonstrating a rare level of political consciousness

\footnotetext{
${ }^{311}$ Governor Edward Twining, 1951, in Pratt, p. 19

${ }^{312}$ Pratt, p. 19

313 Ibid.
} 
among Tanganyikans. ${ }^{314}$ While at Makerere, Nyerere established the TAWA (Tanganyikan African Welfare Association) though he soon amalgamated it with TAA (Tanganyika African Association) which had been established in the 1920s to take a stand against any concept for Tanganyika becoming a region for full-scale white settlement. Nyerere completed his Diploma in Education in 1945 and returned to teach in a Catholic school, St Mary's Mission School in Tabora. For three years he taught history and biology to young and aspirational Africans, before taking another step in his own academic career by moving to Edinburgh to complete a Bachelor of Arts and subsequent Master of Arts. Graduating with an M.A. in 1952, Nyerere was the first Tanganyikan to reach such lofty heights in the European academic world. Historian Laura Kurtz notes that it was in Edinburgh that the foundations of Nyerere's political philosophy were laid. ${ }^{315}$ Returning to Tanganyika, Nyerere found a new teaching position at St Francis College in Pugu. Pugu was a relatively short distance from Dar es Salaam, Tanganyika's largest city and capital. Shortly after his arrival he married his long time fiancée Maria Gabriel, opting for monogamous Catholic matrimony in contrast to his father's polygamy. Shortly after settling into married life, Nyerere began active political participation in the TAA. ${ }^{316}$ By 1953 Nyerere had achieved the position of president of the association and so began practicing his political philosophy. One of his first decisions was to reorganise the association as a vehicle for political activity re-writing its constitution and re-orienting its official objectives. ${ }^{317}$ This perhaps demonstrates the development of Nyerere's growing aptitude for transformation. In May 1954, Nyerere was appointed as a temporary member to Tanganyika's Legislative

\footnotetext{
${ }^{314}$ Kurtz, Laura, Historical Dictionary of Tanzania, London, 1978, p. 151

315 Ibid, p. 152

316 Ibid.

${ }^{317}$ Assensoh, p. 126
} 
Council and a couple of months later was made the first president of the reformed TAA under the new name Tanganyika African National Union (TANU). ${ }^{318}$

Cranford Pratt notes that the establishment of TANU marked the emergence of 'a new type of nationalist' in Tanganyika. Typified by Nyerere, these individuals were young and highly educated. They also had 'not had an earlier chequered career, but who had come to nationalist conclusions and to an anti-colonial commitment by more direct routes. ${ }^{319}$ These men contrasted with the earlier breed of nationalists 'whose pursuit of self-improvement had brought them to a sense of common cause with their fellow Africans in opposition to colonial rule... most can fairly be called members of the emerging bourgeoisie. ${ }^{320}$ Nyerere was successful in uniting these two schools of nationalists and directed TANU toward a national focus, bringing together a variety of rural discontents which had previously only led to regional level agitation. ${ }^{321}$ This helped to create a national consciousness among the agitators; which was one of Nyerere's main aims.

In African One Party States Margaret Bates notes that the timing of the emergence of nationally conscious African activism coincided with the colonial government beginning to feel increasing international pressure. A United Nations Visiting Mission suggested that the government 'ought to establish a timetable for political development, with Tanganyika to achieve independence in twenty years' time. ${ }^{322}$ Bates notes that both Governor Twining and the Secretary of State for Colonies back in London took significant issue with such a suggestion - stating that the British

\footnotetext{
${ }^{318}$ Kurtz, p.152

${ }^{319}$ Pratt, p. 23

320 Ibid.

321 Ibid.

322 United Nations Trusteeship Council, Official Records, 1955, in Bates, Margaret, 'Tanganyika' in Carter, Gwendolen (ed.), African One Party States, New York, 1962, p. 419
} 
government had a pathological dislike for timetables. ${ }^{323}$ Under growing internal and external anti-colonial pressure, the governing bodies of Tanganyika allowed the UN's Trusteeship Council to hear an oral petition from TANU. Nyerere was the obvious choice of speaker. He told the 'Trusteeship Council' that African political development was not occurring fast enough and that unless Africans were assured more substantial progress in the form of political power, then his activist core would pursue a more extreme attitude. ${ }^{324}$ Considering that this petition was heard at the height of the Mau Mau Emergency just across the northern border, a 'more extreme attitude' was an ominous and realistic threat. 'His appearance and his statement made manifest a growing African political sophistication and also unrest. ${ }^{325}$ Nyerere also informed the council that the period of political transition was taking far too long and that African membership on the Legislative Council, limited to three chiefs, no longer constituted sufficient representation of the advancing African opinion. ${ }^{326}$ Nyerere was heralding the emergence of a small yet highly activated African followership - which was increasingly at his disposal.

\section{Mwalimu - Nyerere the moral teacher}

Unlike Kenyatta who traded heavily on his personal prestige in his relationship with his disciples, Nyerere was a teacher - by nature and profession. Later in his leadership career, he was affectionately known throughout Tanzania as Mwalimu, a KiSwahili word for teacher. ${ }^{327}$ Nyerere's vision for TANU, and Tanganyika, was laid out in the organisations 1955 constitution. The TANU constitution took the form of six major objectives;

\footnotetext{
${ }^{323}$ Bates, Margaret, 'Tanganyika' in Carter, Gwendolen (ed.), African One Party States, New York, 1962, p. 420 
1. 'To prepare the people of Tanganyika for self-government and independence, and to fight relentlessly until Tanganyika is self-governing and independent.

2. To fight against tribalism and all isolationist tendencies amongst the Africans, and to build up a united nationalism.

3. To fight relentlessly for the establishment of a democratic form of government, and as a first step toward democracy, to fight for the introduction of the election principle on all bodies of local and central government.

4. To achieve African majorities on all bodies of local and central government, and committees, boards or corporations of public service.

5. To fight for the removal of every form of racialism and racial discrimination.

6. To encourage and organise Trade Unionism and the Cooperative Movement, and to work with Trade Unions and Cooperative Societies and other organisations whose objectives are in harmony with the aims and objects of the Association.' 328

Nyerere set about teaching this vision throughout the wider TANU organisation - and to the Tanganyikan people. In We Must Run While They Walk - A Portrait of Africa's Julius Nyerere, William Edgett Smith notes that 'he toured upcountry Tanganyika almost continuously. TANU's Land Rover, with licence plates DSK 750, became a familiar sight throughout the territory. ${ }^{329}$ Meredith notes that Nyerere pursued his goals with 'missionary zeal' - and carried and presented his message of liberation with much the same evangelistic style and vigour as the European missionaries had done

\footnotetext{
${ }^{328}$ Constitution of the Tanganyika African National Union, Dar es Salaam, 1955

${ }^{329}$ Smith, William Edgett, We Must Run While They Walk - A Portrait of Africa's Julius Nyerere, New York, 1971, p. 82
} 
with their message. Edgett Smith notes that Nyerere's efforts bore considerable fruit and TANU grew at a remarkable rate; 'from one hundred thousand members in 1955 to half a million by $1957 .^{330}$ Political historians Robert Jackson and Carl Rosenberg, as well as Cranford Pratt ${ }^{331}$ agree that Nyerere was becoming more than party organiser. 'Nyerere [was] above all, a teacher, a mwalimu. He [was] a teacher of a special sort. He [was] a teacher of morality. ${ }^{332}$ By the late 1950 's, Julius Nyerere had evolved into the archetypal Burns' style transformational leader. He was engaging with a burgeoning group of followers in such a powerful way that their morality was being affected. As mentioned earlier, he was taking a series of disparate rural discontents against British rule, welding them into a national struggle, whilst teaching the population his vision for self-government. Nyerere was raising the moral deportment of the followership through a process of 'mutual stimulation and elevation. ${ }^{\text {,33 }}$

The rapid emergence of TANU was unintentionally assisted by the colonial government's inertia when it came to African political progress. Governor Twining always asserted that his government's intention was to fulfil the League of Nations/United Nations mandate which was to bring Tanganyika to self-government and independence. Twining, however, also insisted that his policy 'was based on the accepted policy of the British government: non-racialism, with a gradual program of turnover to African control; a plan of carefully graded objectives. ${ }^{, 334}$ Twining refused to have a timetable and this agitated politically conscious Africans in Tanganyika. This saw

\footnotetext{
${ }^{330}$ Edgett Smith, p. 84

331 Jackson, Robert and Rosenberg, Carl, Personal Rule in Black Africa, Prince, Autocrat, Prophet Tyrant, California, 1982, p. 220 and Pratt, p 256

${ }^{332}$ Pratt, p. 256

${ }^{333}$ Burns, p. 4

${ }^{334}$ Edgett Smith, p. 88
} 
opposition 'organised outside of the whole system, ${ }^{335}$ which was precisely what the London policy makers at the Colonial Office were trying to avoid. The inertia sustained by Twining and his government served to swell TANU's ranks - giving Nyerere an increasing mandate with which he could both press the authorities and claim legitimacy as a leader in Tanganyika.

The British administrative officers in Tanganyika mostly viewed themselves as acting out of 'selfless paternalism' on behalf of Africans. ${ }^{336}$ This made the rise of TANU difficult to understand for the British agents. Pratt notes that the senior colonial administrators were hostile to any nationalist agitation as they believed their policies were in the best interests of the colony, and that the agitation of nationalists could undo the laborious work that they had put in. ${ }^{337}$ These officials also believed that they enjoyed the support of the majority of Africans, unless they were 'got at' by agitators. ${ }^{338}$ Governor Twining asserted that the nationalist movement was driven by 'self-seeking individuals' who he believed had appointed themselves as political leaders and were bent on exploiting local grievances in order to advance their position against central government. ${ }^{339}$

The government employed a variety of means to curtail the advances of TANU. Initially they attempted to win the civic debate; 'In June 1958, for example, a Provincial Commissioner urged his District Commissioners to hold open political meetings throughout their Districts... he was sure they could re-establish the confidence of the people. ${ }^{340}$ Pending the ineffectiveness of that approach, the government sought to

\footnotetext{
335 Pratt, p. 24

${ }^{336}$ Ibid, p. 35

337 lbid.

338 Ibid.

${ }^{339}$ Governor Twining, Edward, 'Speech to the Legislative Council, 1954, in Pratt, p. 36

${ }^{340}$ Pratt, p. 36
} 
legislate to limit and control TANU through the 'Societies Ordinance. ${ }^{341}$ Cranford Pratt notes that 'this gave the government a much tighter surveillance of all organisations and placed in its hands the power to refuse or to withdraw the registration of societies for failure to meet the rather demanding formal requirements of registration. ${ }^{, 342}$ It was no surprise that by 1955 the only societies having their registration withheld were branches of TANU. The government's response was comprehensive. Twining's officials were also set the task of rehabilitating tribal chiefs to positions of authority to provide an indigenous counterweight to TANU. This was done in preparation for elections that were soon to be held. The final stroke in Twining's plan was the establishment of the multi-racial United Tanganyika Party (UTP). The rationale was to establish a political organisation loyal to the government that could match TANU's grassroots popularity. The government established an electoral system that favoured the UTP in the anticipated 1957 election, and the now semi-underground TANU rigorously attacked this as an electoral system 'tailor-made for [the] UTP.'343

The existence of the UTP and the proposed 1957 election split the leadership of TANU, with most of the leadership preferring the idea of boycotting the elections. Nyerere argued for participation. Historian William Edgett Smith asserts that this was a pivotal moment in the pre-independence period. Nyerere had to convince the overwhelming majority of the TANU leadership that rather than boycotting, as was their preference, it was in their best interests to participate. ${ }^{344}$ His rationale was that should the UTP win uncontested and subsequently establish themselves as the dominant political force then TANU's major objectives would be set back ten years or more. Nyerere asserted

\footnotetext{
${ }^{341}$ Pratt, p. 37

342 Ibid.

343 Bates, p. 424

${ }^{344}$ Edgett Smith, p. 89
} 
'if we don't participate this year, the UTP is going to win. All members will be returned unopposed and TANU will be fighting from the outside. The only thing we could do is send a petition to the Colonial Office explaining our position; the Colonial Office would send a commission of inquiry; and the next election would be three or four years later; and by that time the UTP would be firmly established. We might get our independence by 1970 or $1975 .^{345}$ Nyerere was demonstrating a visionary capability to lead TANU. He was strategically astute enough to discern that the best long term profitable political choice was electoral participation. In Greenstein's metaphorical terms; Nyerere played a skilled billiards shot within oppressive circumstances. Nyerere's capacity as a Burns style transformational leader was also apparent. He dynamically engaged with the motivations of the actors involved to the extent that their moral orientation on the issue was amalgamated with his own. With TANU opting to participate in the elections Twining's seemingly grand and comprehensive strategy crumbled. The last option available to the administration was the detainment of Nyerere himself, as a final effort to arrest the growth of TANU.

In July 1958 charges were laid against Nyerere for 'criminal libel' arising from his comments in the TANU newsletter 'Sauti ya TANU. ${ }^{346}$ Edgett Smith notes that Nyerere viewed the situation lightly; 'resting at Lady Chesham's farm, he would say lightly, almost jokingly, "shall I go to jail? Every other Prime Minister has gone to jail. But I can't go to jail - it's an election year. ${ }^{, 347}$ Nyerere was referring to what became known as 'the prison apprenticeship' for African independence leaders. Many of them had been imprisoned by colonial powers on questionable charges before they took office. Nyerere's trial coincided with Governor Twining's retirement from Tanganyika and his

\footnotetext{
${ }^{345}$ Nyerere, Julius, in Edgett Smith, p. 90

${ }^{346}$ Bates, p. 427

${ }^{347}$ Edgett Smith, p. 91
} 
replacement with the tall and erudite Sir Richard Turnbill. ${ }^{348}$ Turnbill had previously been employed as the chief secretary in Evelyn Baring's government in Kenya, at the height of the Mau Mau crisis. To the surprise of all observers, and even Nyerere, Turnbill invited Nyerere to Government House for high level talks, two weeks before the conclusion of the trial. Edgett Smith includes a quote of his, justifying his decision; 'tremendous feeling had been aroused. I had been through four years of the emergency in Kenya, and didn't want to go through that again. ${ }^{349}$

Turnbill intervened in the trial and saw that Nyerere did not receive the somewhat coveted title of 'prison graduate' which was 'so often exploited by nationalist leaders elsewhere in Africa. ${ }^{350}$ Turnbill was a different breed of administrator to the likes of Governors Mitchell, Baring and Twining. Turnbill had first-hand experience of what could happen when colonial government ran head on into nationalist agitation. Under his watch there would be no Tanganyikan Mau Mau. Nyerere is quoted in Edgett Smith, reflecting; 'Turnbill could have fallen into Twinning's footsteps and gotten into real trouble, because the political movement was now very militant. ${ }^{\prime 351}$ This is solid evidence to support the claim that the operation of the British Empire depended significantly on the personalities working on the ground, and that a different personality in a key position could significantly alter the course of the Empire's history in a specific context. Greenstein's conceptions of actor location are certainly vindicated through analysis of the British Empire.

In the election of September 1958, TANU or TANU-backed candidates won all fifteen seats on the legislative council. In October Governor Turnbill chaired the new

\footnotetext{
${ }^{348}$ Edgett Smith, p. 92

${ }^{349}$ Sir Richard Turnbill, 1958, in Edgett Smith, p. 92

350 Bates, p. 427

${ }^{351}$ Nyerere, Julius, in Edgett Smith, p. 92
} 
Legislative Council, and in his opening address he announced basic policy changes that essentially recognised the experiment in multiracialism was to be aborted. 'Tanganyika was finally recognised by the British for what it transparently had always been, a predominantly African country. ${ }^{, 352}$ In a second round of elections in February, TANU was only opposed in three seats, which the party won easily, and thus the UTP faded from existence. Throughout 1959 the elected members worked with their remarkably progressive Governor toward a series of proposals focused around the widening of the franchise and the removal of most racial distinctions from the electoral roll. On December $15^{\text {th }}$ Governor Turnbill announced the implementation of these proposals paving the way for self-government and eventual independence. Turnbill called for new elections in September 1960, to establish a Legislative Council with an 'unofficial majority'. ${ }^{353}$ Despite elements of TANU being disappointed the Governor had not gone further, there was jubilation among the politicised African population, and there was dancing in the streets of Dar es Salaam. ${ }^{354}$

In the 1960 elections TANU continued to cement its dominance in Tanganyikan politics. In 58 of the 71 seats available, TANU stood unopposed. Bates notes that the only real electoral contests came from 'intraparty disputes, on the basis of personality and local issues rather than on lines of party policy. ${ }^{355}$ The ascendency of TANU in the 1960 elections gave perceived sanctioning to the belief, circulated by TANU, in the virtues of 'a single independence movement and a strong party that backed the apparatus of the state. ${ }^{356}$ Nyerere was a strong proponent of this centralism, and spoke of one-party

\footnotetext{
352 Pratt, p. 42

353 Bates, p. 429

354 Ibid.

355 Ibid, p. 430

356 Ibid.
} 
democracy and its important role in new states. ${ }^{357}$ After the September elections he was virtually assured a one-party state.

Nyerere was one of independence Africa's most eloquent advocates for the one-party system, so it was no surprise that after TANU's dominance in the September elections that he sought to normalise TANU as the natural governing organisation in Tanganyika. Meredith notes, 'he maintained that the two-party system had evolved in the West as a result of the competition between socio-economic classes' ${ }^{358}$ His belief was that African society was essentially classless, and there was therefore no basis for party competition based on such distinctions; 'parliamentary systems of the kind bequeathed to Africa by Europe's departing colonial powers were misplaced. ${ }^{359}$ Nyerere elaborated;

'The British and American tradition of a two-party system is a reflection of the society from which it evolved. The existence of distinct classes and the struggle between them resulted in the growth of this system. In Africa, the Nationalist movements were fighting a battle for freedom from foreign domination, not from domination by any ruling class of our own. Once the foreign power - the other party - has been expelled, there is no ready-made division among the people. The nationalist movements must inevitably form the first Governments of the new states. Once a free Government is formed, its supreme task lies ahead - the building up of the county's economy. This, no less than the struggle against colonialism, calls for the maximum united effort by the whole country if it is to succeed. There can be no room for difference or division. ${ }^{360}$

Nyerere used this analysis to justify his affiliation to the one-party system. Such analysis failed to take into account some the political luxuries he enjoyed in Tanganyika, compared with elsewhere in the continent. His statement there is no readymade division among the people' of Africa was disastrously proven wrong in

${ }^{357}$ Bates, p. 430

${ }^{358}$ Meredith, p. 167

359 lbid.

${ }^{360}$ Nyerere, Julius, in Meredith, p. 167 
other contexts - such as Nigeria or Rwanda. ${ }^{361}$ The readymade divisions were not often based on class, but in many instances they were based on ethnicity. 'In Tanganyika, Julius Nyerere was helped, as he himself acknowledged, by the fact that the population was divided among 120 tribal groupings, none of which was large enough or central enough to acquire a dominant position. ${ }^{362}$ Armed with the rhetoric of 'uhuru' (freedom/independence), Nyerere enjoyed a near monopoly on galvanising political ideas. He did not have to provide political and material payoffs to dominant ethnic groups to avoid any shattering ethnic conflicts after independence. This meant that with TANU under his control he could prepare to take his position at the apex of the Tanganyikan political structure. Greenstein's theory applied here would indicate that the ethnic diffuse ethnic composition of Tanzania made the political environment more manipulable; thus enhancing the potential for Nyerere's historical impact.

In March 1961 a constitutional conference was held at Dar es Salaam and in May 1961 Tanganyika achieved full self-government. Tanganyika initially was to be a constitutional monarchy, with Turnbill becoming the Queen's representative and Governor-General of Tanganyika. According to Bates, the last steps to independence were taken smoothly. Full impendence was scheduled for the $9^{\text {th }}$ of December $1961 .{ }^{363}$ On this day, climbers ascended Mt Kilimanjaro to place a torch at the summit, 'to cast symbolic rays of hope beyond the country's borders. ${ }^{, 364}$ The transition of power was one of the most peaceful that the continent had seen during the era of decolonisation.

\footnotetext{
${ }^{361}$ Meredith, pp. $193-205$ and pp. $485-523$

${ }^{362}$ Ibid, p. 157

${ }^{363}$ Bates, p. 430

${ }^{364}$ Cartwright, p. 154
} 
Across all of Tanganyika there were no acts of violence reported and, Bates notes, 'the police force spent its time directing traffic., 365

Before Nyerere attained the position of Prime Minister, his political message was simple; he stood for winning independence from the British. His message enjoyed resonance in almost all quarters of African life in Tanganyika. Crudely speaking, at the time of independence, Tanganyika consisted of around ten million Africans, roughly 100,000 Asians and about 22,000 Europeans. ${ }^{366}$ This meant that his overwhelming majority of Tanganyikans were fertile political ground for his message. Nyerere's political leadership was propelled by his ability to not only personify his message, but also to teach it in such a way the masses of the African population, as well as some Asians and Europeans, were elevated by his rhetoric. ${ }^{367}$ When he became Prime Minister, it was expected that he would have no other choice than to accommodate and work within the pre-existing political structures. Beyond the political capital Nyerere had accumulated from his message of anti-colonialism, Tanganyika seemed to offer a leader little to work with in terms of further political transformation. After independence there were few nascent issues or unifying ideals for a leader to interact with. Colonial Tanganyika lacked the class of upwardly mobile and politically articulate Africans who were driving progress in West Africa. ${ }^{368}$ Economically, Tanganyika was resource deprived with very small amounts of arable land and no other significant resources that could generate the state enough resources to empower the leader to forge any new paths. There was also an infrastructural deficit. During the colonial era the British had chosen to focus their development efforts in the more prosperous

\footnotetext{
365 Bates, p. 431

${ }^{366}$ Cartwright, p. 159

${ }^{367}$ Cartwright, p. 163

${ }^{368}$ Ibid, p. 156
} 
northern dependencies of Kenya and Uganda, and their settler dominated southern possessions. ${ }^{369}$ 'There was little to suggest that [Tanganyika] would choose a path markedly different from that of the other states. ${ }^{370}$ Based on this evidence, it could be assumed that Nyerere was obliged to maintain whatever status quo was possible in Tanganyika. Instead, what eventuated in the independence era was one of the most resilient examples of transformational leadership to occur in decolonised Africa.

During the independence struggle, Nyerere had given some hints of his affiliation to the principles of equality. In the 1950's Nyerere had asserted that the high incomes of civil servants and 'other functionaries' were drawn from the labour and toil of the peasantry. ${ }^{371}$ Despite these hints, few suspected his motives when weeks after independence he temporarily resigned as Prime Minister. He had decided to devote himself to developing a coherent TANU governing philosophy that was intended to frame the post-independence period government agenda. Cartwright asserts that his goals were; 'the creation of a non-exploitative, egalitarian society, and a party whose leaders would remain open to criticism and control by the people.'372 These goals were driven by Nyerere's belief, demonstrated in one of his more well-known assertions; 'we in Africa have no need of being converted to socialism than we have of being taught democracy. Both are rooted in our past, in the tradition of the society that produced us. ${ }^{373}$ Nyerere was drafting the blueprint for an African adaptation of socialism. Nyerere dedicated his vast intellectual energy to the development of this philosophy.

\footnotetext{
${ }^{369}$ Cartwright, p. 156

${ }^{370}$ Ibid, p. 167

371 Ibid.

372 Ibid, p. 168

${ }^{373}$ Nyerere, Julius, Essays on Socialism, Dar es Salaam, 1969, pp. 27 - 58
} 
Nyerere's 'sabbatical' of sorts significantly assisted his strategic location within the rapidly changing political environment. This was because it prevented his being tainted as a leader by the relatively small but still significant anticolonial backlash that so much of his core followership demanded. Cartwright asserts; 'there was further advantage to being out of government office in this first flush of Tanganyikan independence. ${ }^{374}$ The British methods of colonial management had built up sufficient political pressures within the Tanganyikan context that needed an outlet once independence took place. 'The government sought to demonstrate African political control by deportations, by advancing Africans over Europeans, and Asians in the civil-service, by bringing in a Preventative Detention Act, and by other actions which seemed both high-handed and racist. These were actions which Nyerere would have had qualms about taking. ${ }^{375}$ Such excess included an incident where 'the British manager of the Palm Beach Hotel in Dar es Salaam asked four Africans - one of whom, he later learned was the mayor of Dar es Salaam - to leave the hotel bar. He was immediately served with a deportation order. ${ }^{376}$ TANU needed to satisfy its activist core who were levelling the demands for the above actions, and Nyerere needed to distance himself from this 'excess. ${ }^{377} \mathrm{In}$ December 1962, when Tanganyika formalised a new republican constitution and the worst of these excesses were out of the way, Nyerere was elected as President by an overwhelming majority of Tanzanians. He was untainted by the process of the new government asserting its control. Nyerere returned full of inspiration and energy to fulfil his transformative plans.

${ }^{374}$ Cartwright, p. 168

375 Ibid.

${ }^{376}$ Edgett Smith, p. 99

377 Ibid. 


\section{Nyerere's presidency and ujamaa}

Nyerere's efforts to rebuild TANU as a vehicle for mass mobilisation in Tanganyika were almost undermined by an army mutiny in January 1964. Nyerere hoped to suppress the mutiny with the internal strength of his new TANU organisation however the rank-and-file membership of the party were slow to come to the aid of their leaders. The mutiny had to eventually be suppressed with the assistance of British marines. The mutiny demonstrated the possible frailty of Nyerere's transformational programme in its embryonic stages. Nyerere's response to the mutiny was an endeavour to reorganise the Tanganyikan military loyal to him and his party. Cartwright notes that this was only partially successful and the military remained a 'vaguely menacing background shadow.' ${ }^{\text {378 }}$

At the same time as the mutiny, there was an African uprising on the offshore sultanate of Zanzibar - that was too close to Tanganyika for Nyerere to ignore. The crisis demonstrated Nyerere's preference to lead independently and often without consultation. The new leaders of Zanzibar were a group of African nationalists and radical Marxists. This drew significant interest from both axes of the cold war and Nyerere discerned that he did not want any proxy-war fought 'on his doorstep. ${ }^{379} \mathrm{He}$ therefore unilaterally decided that Tanganyika would try and persuade the Zanzibari leaders to amalgamate the island state with Tanganyika. His strategy proved successful and in April 1964, Tanganyika became the United Republic of Tanzania - the name change recognising the amalgamation. This move had much expedience for Nyerere's leadership, though it also demonstrated a significant moral trend in his governing style. Whereas other African independence leaders saw interest from Western or

\footnotetext{
${ }^{378}$ Edgett Smith, p. 99

${ }^{379}$ Ibid, p. 169
} 
Eastern powers as a potential resource to be manipulated; 'the more idealistic leaders, such as Julius Nyerere, preferred that Africa should stand aloof from the sterile quarrels of the Cold War. ${ }^{380}$ This could well have been one of the several motivations that led Nyerere to see Tanzania absorb Zanzibar.

With these relatively short-term concerns set aside; Nyerere became pre-occupied again with his long term vision for the independent political development of Tanzania. Whilst extolling the virtues of the one-party state style of government, Nyerere sought to make the system more responsive to the grassroots needs of the citizenry - and therefore democratic. In 1965 he set up a commission to investigate how a de facto one-party state might be made more democratic. The proposals arising from the commission saw Tanzania opt for a system where more than one TANU candidate could contest a seat. These amendments did not significantly democratise the system, though they empowered voters to remove a candidate who was particularly unpopular. ${ }^{381}$ To apply both Greenstein and Burns' leadership theories; by seeking these changes Nyerere was both enhancing his strategic location within the political context; his office was never threatened internally, and to the outside world these actions declared that he was not another post-independence tyrant or dictator. Nyerere was also appeasing the followership in such a way that built trust and loyalty in his leadership.

Nyerere buttressed his international standing by demonstrating a distinctive lack of interest in the spoils of leadership. 'His personal integrity and modest lifestyle was in sharp contrast to the extravagance and corruption for which other African presidents

\footnotetext{
${ }^{380}$ Meredith, p. 143

${ }^{381}$ Cartwright, p. 169
} 
had generally become renowned. ${ }^{382}$ Nyerere also possessed genuine and intense concern for the advancement of egalitarianism in Tanzania - whilst also displaying considerable disdain for any elitism he saw emerging in his new country. He therefore devoted his 'formidable intellectual energy', ${ }^{383}$ to the development of a comprehensive strategy for Tanzania that would both significantly advance egalitarianism whilst purging his country of any elitism similar to that which emerged in other decolonising contexts in Africa. Professor Goran Hyden of the University of Dar es Salaam wrote that Nyerere was making Tanzania 'a political mecca for liberal and socialist progressives from all over the world, anxious to see a challenge to neocapitalism. ${ }^{384}$ Nyerere's good intentions and ability to attract international acclaim also attracted Tanzania material benefits; 'by the 1970s Tanzania benefited from more foreign aid per capita than any other African country. ${ }^{385}$ Essentially Nyerere's high level of integrity, matched with his worthy intentions for his people meant that international observers wanted and were willing to support the success of his projects. To employ the theorists; upon inheriting office, Nyerere's strategic location within an oppressive context seemed to suggest he had few choices in terms of the political direction he could chose for Tanzania. His personal qualities as a leader, however, were a significant enabling force in in both attracting foreign support and assistance for his projects; as well as developing and enhancing the trust and faith his followership placed in his ability to lead. 'Nyerere offers the student of African rulers and regimes an example of a leader whose personal ideals will have made a significant

\footnotetext{
${ }^{382}$ Meredith, p. 249

383 Ibid.

${ }^{384}$ Professor Goran Hyden, Dar es Salaam, Circa 1970, in Meredith, p. 250

${ }^{385}$ Meredith, p. 250
} 
difference not only to personal relations of power in the state, but also to social relations in the wider society.' ${ }^{386}$

In the years following independence an economic gap began to emerge between rural and urban Tanzanians. Urban-dwellers incomes increased in real terms by $65 \%$ between 1960 and 1968. In the same period farmers' incomes remained virtually static. ${ }^{387}$ Nyerere had been propounding the merits of redistributive socialism for years, though he had never taken any significant action to implement these ideals. He had been teaching the virtues of socialist morality and a socialism strongly influenced by his Christian faith across Tanzania since before independence. In 1967, disturbed by the possibility of Tanzania becoming a 'less successful version of free-enterprise Kenya,' ${ }^{388}$ Nyerere took action. Meredith writes Nyerere was 'alarmed that a new acquisitive African elite was beginning to emerge in Tanzania and that traditional communal values were being eroded. ${ }^{389}$ He therefore staged an 'intellectual coup..$^{390}$ On the $7^{\text {th }}$ of February 1967 Nyerere issued a statement of party principles known as the Arusha Declaration. ${ }^{391}$ It is believed that Nyerere wrote the declaration by hand during the Arusha Conference. ${ }^{392}$ The declaration was a call for national self-reliance and placed considerable emphasis on the need for development to begin at the lowest rural level. It also asserted the state's right to control all of the major means of production and trade within the Tanzanian economy. ${ }^{393}$ The Arusha Declaration heralded the practical manifestation of Nyerere's teaching on African socialism. It provided for the comprehensive reorganisation of Tanzanian life around the socialist

\footnotetext{
386 Jackson and Rosenberg, p. 219

${ }^{387}$ Cartwright, p. 168

388 Jackson and Rosenberg, p. 220

${ }^{389}$ Meredith, p. 250

390 Ibid.

391 Ibid.

${ }^{392}$ Kurtz, p. 153

393 Ibid.
} 
principles of 'ujamaa' (family-hood). Following the declaration the government began a program to nationalise the 'commanding heights' of the Tanzanian economy. ${ }^{394}$ Commentators Jackson and Rosenberg assert the 'major financial, commercial, and manufacturing enterprises, many of them foreign owned or the property of Tanzania's Asian minority, were taken over by the state. ${ }^{395}$

Nyerere also emphasised the need for Tanzania to be less dependent on foreign aid. He believed that 'self-reliance' was critical to the success of the project. For it to be realised Tanzania needed to become economically sovereign and independent. He asserted; 'There is in Tanzania a fantastic amount of talk about getting money from the outside. Our governments and different groups of our leaders never stop thinking about methods of getting finance from abroad. ${ }^{396}$ Nyerere was critical of his ministers and civil servants who he asserted were incapable of conceiving a developmental path that did not depend on the attraction of foreign aid. Nyerere believed that self-reliance and independence were synonymous. As long as Tanzania required foreign aid to prosper, his country was still in the clutches of colonialism. He proclaimed 'independence means self-reliance. Independence cannot be real if a national depends upon gifts and loans from another for its development. How can we depend on foreign governments and companies for the major part of our development without giving to those governments and countries a great part of our freedom to act as we please? The truth is we cannot. ${ }^{397}$ Cartwright notes that the policy paradigm was driven by the belief that 'Tanzania had neither any reason nor the right to expect help from other countries in her attempts to achieve economic development, and thus must rely

\footnotetext{
${ }^{394}$ Commanding Heights was a phrase used by Lenin to describe key segments of a nation's economy

395 Jackson and Rosenberg, p. 224

${ }^{396}$ Nyerere, Julius, in Meredith, pp. 250-251

${ }^{397}$ Nyerere, Julius, in Meredith, p. 251
} 
entirely upon her own resources. ${ }^{398}$ As Tanzania did not enjoy any significant resource endowment, Nyerere recognised that the country's best chance for economic independence was through rural development. ${ }^{399}$ Though this development would be slower than that observed elsewhere on the continent, Nyerere believed the development of a sustainable peasant-led agricultural economy would deliver more long term benefits.

The Arusha Declaration was accompanied by a 'leadership code' designed to curb any growth of a privileged African elite as was seen in Kenya and further afield. Nyerere justified the code asserting;

'Many leaders of the independence struggle... were not against capitalism; they simply wanted its fruits, and saw independence as the means to that end. Indeed many of the most active fighters in the independence movement were motivated - consciously or unconsciously - by the belief that only with independence could they attain that ideal of individual wealth which their education or their experience in the modern sector had established as a worthwhile goal. ${ }^{400}$

Nyerere established the code to curb these aspirations. To the consternation of many, ${ }^{401}$ the code stipulated that all senior government or party officials had to also be peasants or workers. These officials were to be in no way associated with the interests of capital. No person employed by the state or TANU would be able to buy shares in private companies or even own rental accommodation. ${ }^{402}$ Cartwright notes that at the TANU conference where the code was ratified there was widespread unhappiness; however Nyerere was successful in persuading the delegates to support it. This was all in stark contrast to the Kenyan experience when Kenyatta actively encouraged the business practices that Nyerere sought to eradicate. The institutionalising of the

\footnotetext{
${ }^{398}$ Cartwright, p. 170

399 Ibid.

${ }^{400}$ Nyerere, Julius, in Meredith, p. 252

${ }^{401}$ Meredith, p. 252

${ }^{402}$ Cartwright, p. 170
} 
leadership code typifies Nyerere as a transformational leader in contrast to one of transaction. Kenyatta managed a loyal body of government officials and operatives through allowing them to enjoy the material pay-offs of his capitalist strategy. This was a political leadership transaction. Nyerere instead saw Kenyatta's strategy as corrupting and sought to revolutionise the morality of his government agents. This was done through teaching the virtues of establishing a 'nation of equals' whilst denying any incentives for government officials to use their offices for material gain. Nyerere also oversaw the placing of restrictions on luxury foreign imports, and significant education reforms designed eliminate any advantages that children of civil servants might enjoy. Nyerere was bent on curbing the growth of any privileged elite.

Nyerere's drive for equality was best exhibited in his proposals for self-sufficient socialist villages to be developed across Tanzania. These villages were to be the fundamental units of rural development. They were to be called 'ujamaa villages,' drawing on the idea of family-hood referenced above. The ujamaa villages were intended to attract the previously scattered rural population into more concentrated living. It was hoped agricultural productivity would be boosted by the increased labour force available and the state's ability to provide the villages with modern agricultural techniques and equipment. 'Strip farms or shambas were to be replaced by large communal units. ${ }^{403}$ Nyerere also held that centralising the rural population in the ujamaa villages would make it easier for the state to provide essential services such as roads, clean water, healthcare and schools. This was Nyerere's 'silver bullet' to address inequality in Tanzania.

${ }^{403}$ Meredith, p. 253 
Nyerere endeavoured to encourage the rural population to move into the villages as he asserted the population had to be willing for the entire project to work. Initially he believed that coercing the population to adopt the ujamaa system would be counterproductive to his overall aims. He asserted; 'an ujamaa village is a voluntary association of people who decide of their own free will to live together and work together for their common good. ${ }^{404}$ Nyerere travelled around rural Tanzania trying to build grassroots support for the ujamaa villages. He would often join with peasants digging their fields as well as attend their local meetings in order to build support for the Arusha Declaration. Cartwright asserts these actions were part of his drive to 'encourage people to decide for themselves what should be done, rather than simply following the governments orders. ${ }^{405}$ This was an archetypal example of Burns' transformational leadership style; 'transforming leadership is a relationship of mutual stimulation and elevation that converts followers into leaders and may convert leaders into moral agents. ${ }^{406}$ The Ujamaa program, however, only saw limited and slow progress.

By the end of 1968 there were only around 180 villages that legitimately conformed to the ujamaa model. ${ }^{407}$ Nyerere tried to speed up the process by offering incentives for the population to move into the model villages and was met with limited success. 'By mid-1973 the number of ujamaa villages had increased to 5,000, involving some 2 million people, or about $15 \%$ of the population. ${ }^{408}$ Meredith goes on to note that many of these were formed only for the prospect of attaining government support in the form of a new water supply or school.

\footnotetext{
${ }^{404}$ Nyerere, Julius, in Meredith, p. 254

${ }^{405}$ Cartwright, p. 172

${ }^{406}$ Burns p. 4

${ }^{407}$ Meredith, p. 254

408 Ibid.
} 
Few villages were genuinely managed in the communal or cooperative fashion that Nyerere had envisaged. One cooperative that was successful was the Ruvuma Development Association (RDA). Beginning in 1963 near the Mozambique border, the RDA had successfully and cooperatively built up infrastructure including a flourmill, sawmill and even a road-transport company. ${ }^{409}$ The management of RDA was required to still participate in a full-share of manual labour and the villagers would share communal meals. The RDA was, however, not under the central control of the government as it had been created four years before Arusha. In October 1969, Nyerere abolished the RDA, one of the most successful examples the ujamaa model - because it was not under the central control of Dar es Salaam. Ironically Nyerere used the Societies Ordinance mechanism to end the RDA; the same mechanism that was introduced by Governor Twinning in the 1950 's to control TANU. ${ }^{410}$ This perhaps demonstrates an aptitude, also exhibited by Kenyatta, for Nyerere to employ colonial era mechanisms created for political control, to enhance his strategic position within the political environment. Despite Nyerere's rhetoric about transforming Tanzania to exist in genuine 'uhuru', free from any colonial hangovers - he was willing to govern, in some respects, in a similar way to the former British governors; autocratically. This was perhaps best demonstrated in the next phase of the ujamaa program.

Frustrated with the slow progress of the program, and the reluctance of many Tanzanians to embrace his vision, Nyerere became impatient to see the fruits of his transformative program. Cartwright recalls, 'in 1973 Nyerere openly abandoned the reliance on persuasion for rural transformation, announcing... it was time to force

\footnotetext{
${ }^{409}$ Cartwright, p. 172

410 Ibid, p. 173
} 
people to move in order to save them from continuing "life of death". ${ }^{411}$ In a radio broadcast he lauded the benefits his government had brought to the rural population such as clean water, healthcare and education, and asked what the peasants had done in return - inferring that they had done nothing. The broadcast concluded with Nyerere admitting he could not turn people into socialists by force, but he could ensure that everyone lived in a village. ${ }^{412} \mathrm{He}$ therefore set his government the target of having all rural Tanzanian's moved into the villages by 1976. In order to meet the deadline party officials and district administrators began planning 'operations' that were to involve truckloads of rural people being 'dumped' onto new sites. ${ }^{413}$ Unfortunately for the displaced persons, minimal preparation was done to get the sites of their new villages up to standard; as the government officials doing the planning did not have to live with the outcomes. This was deeply reminiscent of the colonial era. The government officials were also responsible for burning the homes and crops of the transported villages, so as to prevent them from returning once moved. ${ }^{414}$

Between 1973 and 1977 around 11 million people were moved into new villages. Meredith asserts that was one of the greatest mass movements in African history. Nyerere strategically employed this figure, telling his people and the world that such a movement could not have been accomplished by force and that the move was overwhelmingly voluntary. 'Eleven million people could not have been moved by force in Tanzania; we do not have the physical capacity for such forced movement, any more than we have the desire for it. ${ }^{415}$

\footnotetext{
${ }^{411}$ Cartwright, p. 174

${ }^{412}$ Meredith, p. 255

${ }^{413}$ Cartwright, p. 174

414 Ibid.

${ }^{415}$ Nyerere, Julius, in Meredith, p. 255
} 
Whether this mass migration was a consequence of transformative leadership and Nyerere's conversion of enough of the population into moral agents, or whether it was an example of naked power wielding remains contentious. It was likely a combination. Nyerere was correct in asserting the Tanzanian state, and all the resources of TANU were not capable of orchestrating such a move against the will of the people, however, stories of brutality and coercion were too common to allow Nyerere to claim he had the complete cooperation of the Tanzanian people. Even writers sympathetic to the experiment such as French writer Sylvain Urfer, articulated some of the harsh realities of the villagisation; 'it was as if a tidal wave had washed over the country, with millions of people being moved in a dictatorial manner, sometimes overnight, on to waste land that they were expected turn into villages and fields. ${ }^{416}$

Meredith writes that the disruption caused by the villagisation almost caused catastrophe with food production falling drastically and the incidence of famine spreading across the country. ${ }^{417}$ Nyerere's government attempted to mitigate the food supply crisis with food imports, though this almost completely depleted Tanzania's foreign exchange reserves. Eventually Nyerere was obliged to turn to the World Bank and International Monetary Fund for the fiscal assistance he needed to among other things, feed his people. A project in self-reliance spun-out into large scale dependence on international aid and assistance. By 1979 90\% of Tanzania's population had been moved into ujamaa villages, yet the collectivised system of agriculture was only producing $5 \%$ of Tanzania's agricultural output. ${ }^{418}$

\footnotetext{
${ }^{416}$ Urfer, Sylvain, Une Afrique Socialiste: Ia Tanzanie, 1976, in Meredith, p. 256

417 Meredith, p. 256

${ }^{418}$ Ibid, p. 257
} 
The program of state control of the commanding heights of the economy was no more successful. The nationalisations spawned a number of state controlled enterprises that were systemically inefficient. They were 'incompetently managed, over staffed and mired in debt. ${ }^{419}$ Myriad state commercial organisations were established to provide banking and insurance services, as well as manage state farms, state marketing boards and even state shops. Meredith notes that these organisations were run by managers who behaved more like bureaucrats than businessmen. They ran their organisations as though they were part of the civil service, which created unfortunate levels of patronage within the economy. ${ }^{420}$ Members of the workforce came to believe their jobs were permanently assured by the socialist state - significantly limiting workers motivation and efficiency. Nyerere made a speech in 1977 entitled 'The Arusha Declaration Ten Years After,' in which he 'bitterly complained' about the chronic inefficiency within the bloated state sector - arising from the 'indifference and laziness of managers and workers. ${ }^{421}$ Nyerere asserted; 'It is essential that we should tighten up on industrial discipline. Slackness at work, and failure to give a hard day's effort in return for wages, is a form of exploitation; it is an exploitation of other members of society. And slackness has undoubtedly increased since the Arusha Declaration was passed. ${ }^{422} \mathrm{~A}$ Burns and Greenstein explanation of this dilemma could hold that the moral orientation of significant numbers of the citizenry had remained untransformed by Nyerere's fervent teachings on socialism, and therefore formed an oppressive block within the situational context that had considerable potential to derail Nyerere's goals.

\footnotetext{
${ }^{419}$ Meredith, p. 257

420 lbid.

421 Ibid.

${ }^{422}$ Nyerere, Julius, 1977, in Meredith, p. 257
} 
Cartwright explores this idea, relating it back to the colonial era. 'Actions under colonial rule, and the fact that colonial authorities had so much more power than previous rulers to enforce their edicts, left a legacy of deep suspicion and distrust of "the government". ${ }^{423}$ During the colonial era it was prudent for the African to lay low when any government officials appeared; because 'even an innocent census question about one's children or cattle or crops might be the prelude to a new tax. ${ }^{424}$ Colonial officials further contributed to the distrust by taking the line that such evasiveness was best treated with force rather than persuasion. These perceptions of government were not alleviated by attempts to enfranchise Africans during the decolonisation; Cartwright muses, 'the reality of government for most Africans was authoritarian power wielded in an unpredictable and capricious manner. ${ }^{, 425}$ The colonial era also saw Government viewed primarily as an external entity which existed for the extraction of profits for the benefit of others elsewhere. Common perception was that government was 'alien and arbitrary' - and this did not inspire loyalty. Cartwright asserts that even with African's of the calibre of Nyerere in control, this perception was slow to change. 'The suspicion of government... made it very difficult for any leader to mobilise popular enthusiasm for a government-led development effort. ${ }^{, 426}$ Therefore, despite Nyerere's considerable transformative leadership skill, the situational context had framed the orientation of the followership toward the government. This meant that Nyerere could not inspire key quarters to involve themselves in his development project. Furthermore, acknowledging the government was historically 'alien and arbitrary,' members of the citizenry had no traditional loyalty to it -meaning some individuals did not suffer any moral problems when

\footnotetext{
${ }^{423}$ Cartwright, p. 13

424 Ibid.

425 Ibid.

${ }^{426}$ Ibid, p. 16
} 
extracting unintended benefits from it. This fits within Burns' framework as elements of the followership in this case fit within his follower classification as 'apathetics.' Their apathy toward the leader-follower relationship was frustrating Nyerere's leadership endeavours.

Despite Nyerere's best efforts to encourage Tanzanians to come behind the project and work towards it, the state enterprises continued to operate in the same fashion. The Tanzanian economy became beleaguered by the inefficiency and the huge and recurring losses the state enterprises incurred. Towards the end of the 1970s the situation did see some improvement with the food supply recovering, though Tanzania was still running 'a serious balance-of-payments deficit.' ${ }^{427}$ In 1978 Tanzania's economic problems were compounded again with drought, the rising cost of oil and a war to end Idi Amin's brutal dictatorship in Uganda. Nyerere's decision to commit the Tanzanian military to ending Amin's tyrannous regime demonstrated his high level of moral purpose, however also highlighted his inability to fully comprehend the economic ramifications. Cartwright argued, 'the war... was clearly one of the most justifiable wars in history, but it dealt Tanzania's economy a costly blow. ${ }^{428}$ More than half of Tanzania's limited export earnings were dedicated to the war effort between in 1978 and 1981, the other half was consumed by oil imports. Nyerere's economic woes were compounded by a drought during the same period which dramatically reduced Tanzania's grain production. This combination of problems forced Nyerere to go to the international community 'cap in hand' for food aid and long term loans. ${ }^{429}$ The international community responded, and by 1982 the annual level of foreign aid

\footnotetext{
${ }^{427}$ Cartwright, p, 178

${ }^{428}$ Ibid, p. 179

${ }^{429}$ Ibid, p. 179
} 
reached $\$ 600$ million. ${ }^{430}$ Without these funds 'Tanzania would have plunged into penury. ${ }^{431}$ As Tanzania entered the 1980 's, the country was more reliant on foreign assistance than before Arusha. In a state broadcast to mark twenty years of independence, Nyerere admitted to his people 'we are poorer now than we were in 1971. ${ }^{432}$ Nyerere's navigation of his highly oppressive situational context had crippled his leadership agenda. Meredith writes that Nyerere's achievement was related not to the success of the strategic path he had chosen, 'but to his ability to persuade foreign sponsors that his objectives were sincere. ${ }^{433}$

Despite Nyerere's woeful economic record, analysis must take into account some of the significant successes of his leadership. As a result of Nyerere's leadership efforts, Tanzania had diverted substantially from the course of many of its decolonised counterparts. For example in the field of education, health and social services Nyerere oversaw near unprecedented improvements. In 1976 Nyerere's government had achieved a $66 \%$ literate population, one of the highest levels in Africa. ${ }^{434}$ Primary school enrolment increased from one quarter of the school aged population to $95 \% .{ }^{435}$ $40 \%$ of villages in Tanzania were given access to clean tap water and $30 \%$ had health clinics. ${ }^{436}$ Nyerere also oversaw life-expectancy increasing by ten years from forty-one to fifty-one years. ${ }^{437}$ According to Cartwright, Tanzania had done more than almost

\footnotetext{
${ }^{430}$ Meredith, p. 259

431 Ibid.

${ }^{432}$ Nyerere, Julius, 1981, in Meredith, p. 258

433 Meredith, p. 259

${ }^{434}$ Cartwright, p. 179

${ }^{435}$ Meredith, p. 259

${ }^{436}$ Ibid, p. 259

${ }^{437}$ Ibid.
} 
any African state to distribute the benefits of healthcare and education 'down to the ordinary farmer in the bush. ${ }^{438}$ This element of ujamaa was successful.

In 1985 Nyerere announced he would retire after the elections held later that year. He was to leave Tanzania one of the world's poorest countries. What resources were available in Tanzania were relatively evenly distributed among the populous, something truly distinctive in the context of decolonised Africa. ${ }^{439}$ Also distinctive in the context was that Nyerere was one of six African heads of state out of the 150 who had 'trodden the African stage,' to voluntarily relinquish power. ${ }^{440}$ He remained the Chairman of the Chama cha Mapinduzi (reformed TANU) until the 1990s, in a role akin to being an elder statesman. Perhaps one of the more accurate appraisals of Nyerere's presidency came from a Dar es Salaam market trader, Winnie Naali, who upon Nyerere's death in 1999 wore a black cloth with Nyerere's image imbedded as a mark of respect for Mwalimu. Winnie told a reporter, 'He was not very clever at economics and this was not good for the wealth of the country, but when he realised this, he said sorry and resigned. He wanted Tanzania to be one big village, a family for us all, and for all of us to take part. ${ }^{, 44}$

\section{Theoretical Questions of the Leadership of Julius Nyerere}

1. How strategically well placed was Julius Nyerere to affect meaningful political change in the selected environments? (Greenstein)

Nyerere completely altered the course of history in Tanzania. He was located within some areas of political life to affect change in an intense and lasting way. The

\footnotetext{
${ }^{438}$ Cartwright, p. 179

439 Julius Nyerere in Encyclopaedia Britannica Academic Addition

http://www.britannica.com/EBchecked/topic/423105/Julius-Nyerere (Accessed 15th September, 2012)

440 Meredith, p. 379

${ }^{441}$ Smith, Alex Duval, 'Tanzania Weeps for Father of the Nation' in The Independent, $20^{\text {th }}$ October, 1999
} 
environment itself, however, was in other ways highly resistant to change. Some of this resistance was overcome by Nyerere's leadership, and some of the environmental resistance overcame Nyerere. Nyerere's formidable intellectual energy and personal integrity saw him acquire considerable respect within Tanzania's first governing organisation TANU. This empowered his leadership as he was never encumbered by any significant internal challenges to his office. Nyerere also had at his disposal a popular and willing party organisation. His cementing of the one-party system in Tanzania further enhanced his strategic position as electoral competition was never a tax upon his political energy. Nyerere's ability to pre-emptively discern his evolving political context also gave him the ability to better locate himself within the leadership environment. Nyerere's limited resources, however, significantly oppressed his leadership and endeavours toward his goals. His noble and experimental goals and aspirations in national 'family-hood' were consistently undermined by the economic unviability of the ujamaa project. Nevertheless, Nyerere's transformation and therefore historical impact upon Tanzania was immense. Whilst the lack of economic resources undermined the project, the fact that Nyerere made it last so long - and that it saw so many Tanzanian lives irrevocably changed, was remarkable. The lack of economic resources in Tanzania may well have also empowered the project in that there were not any established or major vested economic interests motivated enough to challenge Nyerere's leadership. Thus his strategic location was further enhanced.

2. How and to what extent did the psychological predispositions of the 'followership' in Tanzania (at different times and phases) enable or disable the Nyerere's ability to lead, and therefore affect historical outcomes? (Burns, Maslow) 
The psychological predispositions of the 'followership' were one of the major challenges to Nyerere's leadership. Nyerere was a classic case of Burns' transformative leader. This meant that his leadership was concerned with dynamically interacting with the followership in such a way that their motivations and aspirations were amalgamated with his own. At times Nyerere delivered such prophetic political teaching that the 'followership' was genuinely on-board with his project. This was often driven, however, by a pre-existing and underlying desire for independence among the citizenry. Nyerere could not tap into such nascent issues to support his leadership toward African socialism; they simply were not there. Employing Maslow; the followership did not necessarily see how their 'esteem' or 'self-actualisation' needs were to be fulfilled living in ujamaa villages. In fact their more basic needs of food and security were actually threatened by the programme. This created significant apathy within the followership toward Nyerere's transformative agenda. This, to an extent, disabled Nyerere's leadership.

3. What were the other forces that made up the 'situational array' in Tanzania, and how stable or unstable were they? (Greenstein)

The 'situational array' that framed Nyerere's leadership contained both stable and unstable elements. In contrast to Kenya, nationalist feeling had not built up to the same radical and violent levels as were demonstrated by the Mau Mau. Tanzania did not see a brutal and violent anti-colonial uprising. In this way the situational environment was more stable and more suitable for Nyerere's leadership to affect meaningful historical change. This contrasts with Greenstein's theory that the higher the level of environmental restructuring, the greater the potential for a leader to make a historical impact. Once Nyerere had taken office the British Government was 
supportive of Nyerere which had a stabilising impact upon his leadership. Also significantly influencing the situational array of historical forces around Nyerere were events in Kenya. The horror and brutality of that anti-colonial struggle meant that British actors, such as Turnbill were anxious to avoid any reappearance of a Mau Mau equivalent emergency in Tanzania. This increased the rate of environmental restructuring in Nyerere's milieu, as after Governor Twining's administration the British were quite accepting of change as a political fact. This also had a stabilising effect as it meant Nyerere and his followers carried out their independence struggle within a pre-existing governing framework, rather than working from the outside.

The distinctive lack of a numerous, landowning and vociferous European settler population was another feature of Nyerere's situational array. Elsewhere in Africa the presence of such a group formed a considerable part the political environment that independence leaders had to navigate. With only around 22,000 Europeans, Nyerere was largely spared from this complication within the strategic environment. This was a stabilising feature of the environment as it limited the potential for problems around ethnic conflict and resource distribution. It may have also had a limited destabilising impact after independence. Kenyatta, for example, was quick to capitalise on the European population's experience and ability to support his government while Nyerere could not enjoy this benefit to the same extent. This meant that with low levels of indigenous education at the time of independence, Nyerere had to recruit a potentially less able civil service to support his leadership goals.

The diffuse nature of African population in Tanzania also had a stabilising and enabling impact upon Nyerere's leadership. In Nigeria for example, one of the major hurdles any leadership has to overcome is the strength and assertiveness of the major 
ethnicities within that country. In Tanzania there were 120 ethnic groupings among the African population, none of which large enough to attain a dominant position. This stabilised the political environment, further avoiding any potential ethnic conflict a leader could be exposed to. This assisted Nyerere's leadership as his situational array or 'billiard table' was also spared this complication.

4. Did Julius Nyerere possess the peculiar strengths required to engage the 'followership' and direct them toward a meaningful goal and thus manipulate the situational array - or was the situational array too oppressive for even the most skilful political actor to manipulate? (Greenstein, Burns, Maslow)

Nyerere possessed remarkable skill in the delivery of his message and vision for Tanzania. He was often likened to more of a preacher than a politician and was affectionately known as mwalimu -a great teacher. When he died in 1999, Tanzania stopped. This was excellent evidence of the extent to which he had dynamically engaged with the followership, through his use of his peculiar strength as a moral teacher. The direction of the followership toward a meaningful goal was more complex. Whilst Nyerere enjoyed nationwide adoration, his ability to guide the citizenry in a direction determined by his leadership was undermined. His agents did not share his vision, and thus corrupted the noble goals of the ujamaa project. This coupled with Tanzania's meagre economic resources made the situational environment too oppressive to complete the transformation Nyerere was seeking. According to Maslow's hierarchy, actors are motivated by 'needs'. Despite Nyerere's gift for the visionary and moral teaching of his ujamaa goals, the agents he needed to action the programme did not share the vision. It was hard to see how their 'esteem' or 'self-actualisation' needs could be fulfilled under 'ujamaa', as the programme 
sought to make them equal with the lowliest of peasants. This framed the situational array to the extent that despite Nyerere's unique abilities, he was unable to manipulate the environment for the full achievement of his goals.

5. To what extent was the British method of colonial development and management responsible for the answers to the above questions?

In the Tanzanian experience, the British method of colonial development and management was different to its normative approach in other parts of Eastern and Central Africa. This was driven by several forces. The acquisition of Tanganyika as a League of Nations Mandate and subsequently a United Nations Trusteeship meant that the paradigm for its colonial management was significantly different to that which framed the British approach during earlier times as part of the 'Scramble for Africa'. At the time of its amalgamation into the British Empire, London's lust for international expansion and dominance was, along with its financial resources, largely spent. Whilst the acquisition of the Tanganyika Territory completed Cecil Rhodes' vision of an empire stretching from Cape Town to Cairo, the attainment of this dream had lost substantial support by the end of the First World War. The Tanganyika Territory was never therefore a colonial project of significance the way neighbouring Rhodesia and Kenya were. Another force that differentiated the British approach to the Tanganyika Territory from their other African possessions was the perceived lack of value they placed on the territory. East Africa was already considered a backwater within the expansive empire. This was demonstrated by how Britain chose to place the quality of their colonial administrators. Murray-Brown noted, 'East Africa did not attract the highest grade of colonial official - India and the Sudan took the cream of the university 
graduates. ${ }^{442}$ In the context of East Africa, the Tanganyika Territory was a considered backwater, and a poor one at that. This meant that it received limited policy initiatives and development from the Colonial Office, other than the generic 'long apprenticeship' for self-government. The 'long apprenticeship' was to be achieved through a policy of 'multi-racialism' that was in keeping with the British approach to the region. The policy of multi-racialism was a façade for assuring the continued dominance of the Governor and the political restraint of the overwhelming African majority. This was frustrating enough for members of the African population to drive the emergence of an underlying anti-colonial feeling. It was this feeling that Nyerere's leadership was able to build upon.

The British perception of Tanganyika as a low-value possession meant that, when the nationalist movement gained traction, the resistance arising from the colonial establishment was less significant than elsewhere. This coupled with the unique personalities of Governor Turnbill and Nyerere, meant that the eventual transition of power was completed peacefully and from within the pre-existing institutions. The degree of stability that this in turn generated had a positive impact upon Nyerere's leadership, and the country as a whole. The goodwill arising from the peaceful transition that existed between Whitehall and Nyerere was also an enabling force in his leadership.

The British Government had attempted to pursue pre-independence policies that may have limited Nyerere and TANU's ability to establish an impregnable political position, a position that scuttled any chances of electoral competition in the independence era. These policies were, however, undermined by an institutional inertia displayed by the

\footnotetext{
${ }^{442}$ Murray-Brown, p 58
} 
Governors of Tanganyika before Turnbill. In this way Nyerere's strategic position postindependence was unintentionally enhanced by the earlier intransigence of Governor Twining to enfranchise and include more Africans earlier, in the political process.

The British treatment of the Tanganyika Territory as a backwater significantly hampered post-independence economic development, which in turn impacted upon Nyerere's leadership. The infrastructural deficit, as well as the lack of education and healthcare available in Tanganyika contributed to the economic challenges that eventually proved to be his undoing. In this way his strategic location was weakened by a lack of investment by the British (and Germans) throughout the colonial era in the territory. Nyerere was not successful in converting enough of the followership to sharing his vision for the solution to these problems. Therefore they hurt his leadership endeavours significantly. This was, to an extent, off-set by the support the British, and other international aid donors provided Nyerere when his economy was in ruins. 


\section{Conclusion}

'The very fact of most African state's newness, and the consequent fluidity of their political systems, has given great scope for leaders to take them in a wide variety of directions. Their fragile institutions and weak civic culture have paradoxically both limited what a leader can do and at the same time enhanced his power. ${ }^{443}$

In the 1960s and 1970s Africans reasserted themselves as fundamental actors in the process of determining the future of their continent. At the head of this reassertion were the political leaders. They optimistically assumed the mantle; many with the intent of seeing their inherited colonial states take their 'place in the sun. ${ }^{444}$ This gave rise to a new political leadership phenomenon; decolonised African leadership. This thesis has explored two examples of this phenomenon, Jomo Kenyatta and Julius Nyerere. It has articulated the unique forces that have interplayed with their leadership experiences, as directed by the theorists James McGregor Burns and Frederick Greenstein. Abraham Maslow was also employed to buttress the Burns' approach to the analysis of leadership. Their theories guided the researcher to look to the dynamic interplay between the leader and their political environment as the fundamental place to analyse their experiences. This direction was well suited to the selected cases. The unique environmental forces that framed these leaders' experiences were one of the major distinctions of this new leadership phenomenon. This thesis sought to place extra focus on one of the environmental forces; the British method of colonial development and management. In highlighting the extent to which the methods of British colonial administration interacted with the leadership experiences of Jomo Kenyatta and Julius Nyerere, this thesis intends to assist further

\footnotetext{
${ }^{443}$ Cartwright, John, Political Leadership in Africa, London, 1983, p. 2

${ }^{444}$ Mussolini's reference to prosperity and international prestige
} 
scholarship in the conceptualisation of the dynamic leadership environment faced by the early generations of decolonised African political actors.

This choice of approach led the researcher to articulate the nature of the British Empire, through the analysis of its philosophical foundations, through to its modus operandi, and subsequently how this differed across contexts. With this analysis established, focus was applied to how the Empire manifested itself within the selected contexts. In the twentieth century, considerable cleavage was observable, between the enlightened philosophical approach to Empire that was advanced by the Colonial Office in London, and the practices of Britain's colonial agents on the ground. This understanding formed a critical dynamic of this thesis. The extent to which British colonial activity framed post-colonial leadership was based on a dichotomy. A theme recurrent in this thesis was the Colonial Office attempting to implement policies for the enfranchisement of Africans and increases in their participation in civic affairs. These attempts were often then corrupted by a considerable institutional inertia that existed within the colonial service. This in turn meant that the personalities of the British operatives in the selected environments were just as important a unit of analysis as the colonial policies emanating from Westminster. These realities supported the necessity of articulating the narrative of the unique British operations in each of the selected environments; as generalisations prove problematic.

In Kenya, it was discovered that British operations were often dictated by the powerful and vociferous European settler minority and at other times by the sole discretion of the autocratic office of the Governor. This side-lined the Colonial Office, along with its preference for African inclusion. This proved to be a significant environmental influence during the independence struggle, and upon the leadership of Jomo 
Kenyatta. Britain's war-time colonial policies also proved to be a substantial contribution to the post-colonial leadership environment. British methods of African recruitment had seen their village societies reorganised to the extent that for a brief period tribal animosity was broken down, and Britain had become the 'common oppressor.'

The environmental dynamics of Kenya in the mid-twentieth century were framed by an apparent cooperation between key settler stakeholders and the Governor, to retard African political progress. This was a major environmental contribution by the British to Kenyatta's leadership equation. The resistance to change saw political pressures build up to an extent that not even Kenyatta could control their outburst. This outburst was the Mau Mau Emergency; a near decade long struggle that grew into one of the British Empire's most significant twentieth century African legacies.

In Tanzania (or Tanganyika as referred to at the time), the British Empire's appearance and operations was significantly different. They framed the leadership environment in a distinctive way to that was observed in Kenya. Tanganyika was not the valued possession that Kenya was, and was never chosen as a location for organised settlement. Tanganyika did not offer the British any noteworthy resource endowments, or any large and utilisable labour force. This saw the territory governed as an almost after-thought - with only loose regional policies applied, if any. Whilst the same institutional inertia was observable through governors such as Twinning, the Empire's manifestation in Tanganyika had a different impact on the post-colonial leadership milieu of Julius Nyerere.

Frederick Greenstein's prism was effective in encompassing how the above imperial operations fed into the leadership equation. Greenstein's billiard table metaphor for 
conceptualising the location of the actor within an evolving milieu proved especially useful. Greenstein's prism efficiently led the researcher to uncovering how British operations framed post-colonial leadership. This was through the establishment of leadership context; and how such operations created an oppressive or manipulable political environment that tested the peculiar strengths and weaknesses of the actors. Greenstein's contribution in regard to 'environmental restructuring' was also helpful. It directed the researcher to look to the extent to which the environment around the leader was evolving as a means of discerning how meaningful their historical impact was likely to be. In both cases there were high levels of environmental restructuring present, as this was the nature of decolonisation. These high levels of restructuring, however, cannot be assumed to have gifted the leaders the ability to affect history by taking their countries in any direction they chose. It perhaps was best demonstrated in the Nyerere case, while restructuring did occur, there were also underlying elements of the situational context that were fixed, and non-navigable for even the most skilful political actor.

Theorist James McGregor Burns (supported by Abraham Maslow) advised the researcher to analyse the relationship between the leader and context through the following prism. Burns' directs the researcher to scrutinise the relationship between the leadership and followership as the primary means of understanding and classifying the type of leadership they are observing. Burns' transformational typology was observable in both the Kenyatta and Nyerere cases, though significantly more in the latter than the former. Burns held that transformational leadership occurs when a leader is able to mobilise their understanding of nascent issues within the followership to the extent that they can manipulate that group of followers' moral orientation 
toward the leaders' goals. Critical here is the acknowledgement of when nascent issues did and did not exist, with special interest in how the British colonial methods influenced this. For example, both subject leaders were successful in engaging with underlying colonial resentment, and guiding it within their own leadership goals to great effect. In the post-colonial era, however, this process became more complex. Kenyatta took a 'transactional path' post-independence, in that rather than trying to transform the morality of the citizenry, he sought to achieve leadership through a series of transactions with the various groups of followership. Kenyatta offered stability and prosperity - which saw the increasing satisfaction of Maslow's needs within key aspirational groups, and in exchange, those key groups allowed Kenyatta to pursue the one-party state, and to make himself politically impregnable.

Nyerere's approach was different. In the post-colonial era, he pressed on with a transformative agenda. He sought to further teach his philosophy to the followership in such a way that he hoped their morality would be elevated to a similar level as his own. Whilst noble, this approach failed to recognise a critical element of successful transformational leadership as held by Burns. Despite Nyerere's 'Ghandian' efforts to preach the virtues of his ujamaa philosophy to the followership - the necessary underlying feeling within the followership was not available for Nyerere to manipulate or guide. Nyerere needed at least a core-group of committed agents who had been converted to his vision to complete the transformations he was seeking. Unfortunately for the lofty goals of ujamaa, such a group did not exist. In this way Nyerere's desire to see his country transformed along the lines of his African socialist philosophies was continually frustrated by a lack of affiliation to his goals displayed by the very people he most needed to implement them. 
In both cases it appeared that without Britain 'the common oppressor', post-colonial transformational agendas seemed elusive. The nascent and uniting political issues were sparsely available to leaders for the mobilising and manipulation of the followership toward their goals. This resulted in leaders either settling for a transactional approach as occurred in Kenya, or alternatively suffering ultimately abortive transformational efforts, as occurred in Tanzania. The synthesis of this idea with Maslow and Greenstein's theoretical contribution is perhaps best visualised in the following diagram.

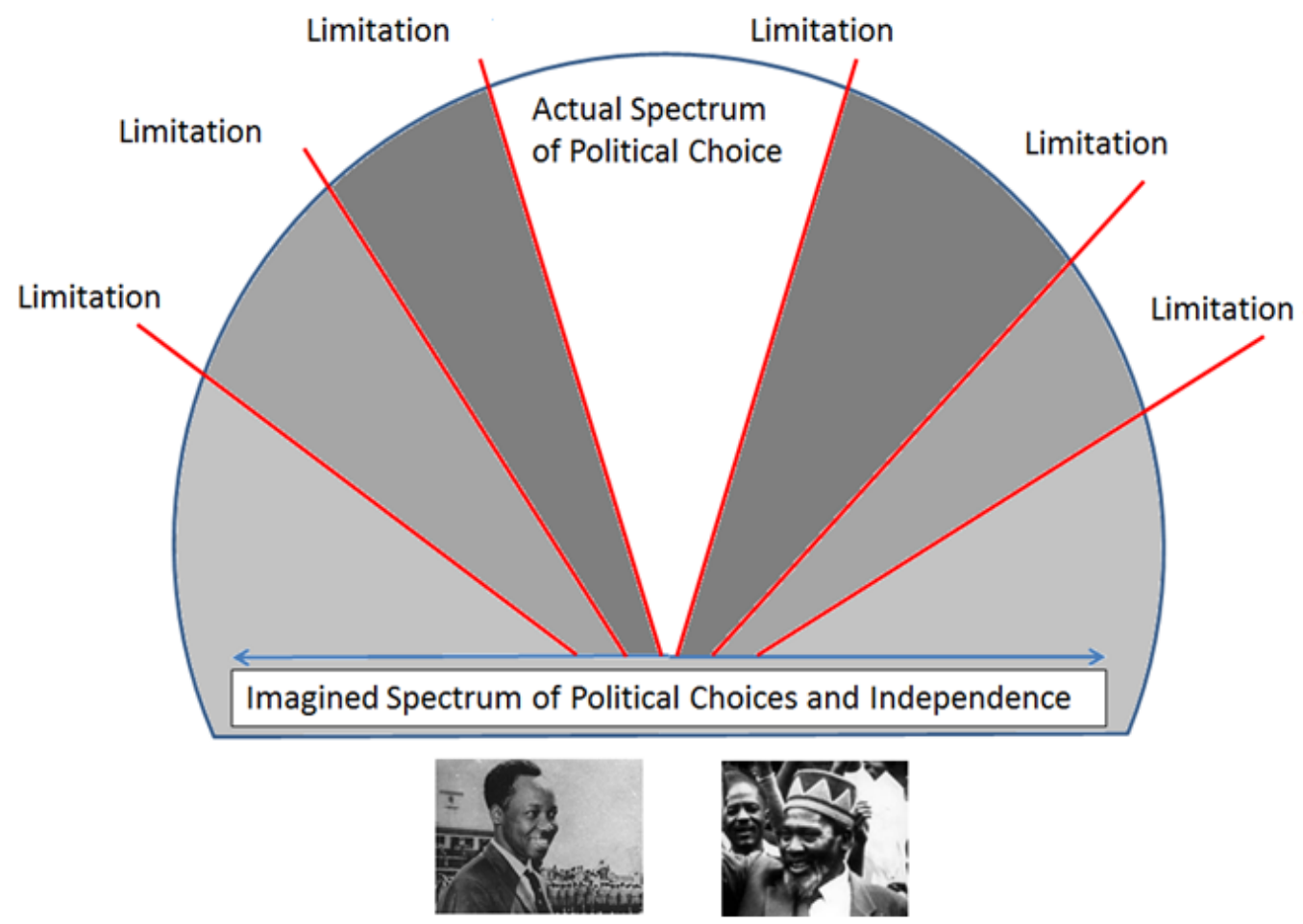

Figure 4.1 - The imagined spectrum of political choices vs. the actual spectrum of choices available to leaders at independence

Jomo Kenyatta and Julius Nyerere had honourable goals that motivated their leadership endeavours. At independence the relationship between these leaders and their followers was framed by high levels of confidence and optimism. Both leaders saw some of their optimistic goals achieved and succeeded in improving the lives of 
many of their followers. Their leadership environment was, however, undeniably oppressive and limiting. Upon inheriting 'uhuru' the leaders believed they had a wide spectrum of political paths upon which they could embark. The reality was different. There were structural limitations within the milieu which could not be overcome; many of which were bequeathed upon Nyerere and Kenyatta by their British predecessors. 


\section{Bibliography}

Anderson, David, Histories of the Hanged - The Dirty War in Kenya and the End of Empire, London, 2005

Arnold, Guy, Kenyatta and the Politics of Kenya, London, 1974

Assensoh, A.B., African Political Leadership, Florida, 1998

Bates, Margaret, 'Tanganyika' in Carter, Gwendolen (ed.), African One Party States, New York, 1962

Boyce, D. George, Decolonisation and the British Empire, 1775 - 1997, London, 1999

Brendon, Piers, The Decline and Fall of the British Empire - 1781 - 1997, London, 2007

Burns, James McGregor, Leadership, New York, 1979

Cartwright, John, Political Leadership in Africa, Kent, 1983

Chidzero, B. T. G., 'African Nationalism in East and Central Africa, in International Affairs (Royal Institute of International Affairs), Volume 36, Number 4, 1960

Corfield, F.D. Historical Survey of the Origins of the Mau Mau, London, 1960

Cox, Richard, Kenyatta's Century, London, 1967

Darwin, John, Britain and Decolonisation - The Retreat from Empire and the Post-War World, 1988

Darwin John, in Stockwell, Sarah, The British Empire - Themes and Perspectives, Massachusetts, 2008

Doro, Marion. E, and Stultz, Newell. (eds), Governing in Black Africa-Perspectives on New States, 1970, New Jersey, 1970

Drayton, Richard,'Review of Richard Gott - Britain's Empire' in The Guardian, 2011 http://www.guardian.co.uk/books/2011/dec/07/britains-empire-richard-gott-review (Accessed 4th July 2012)

Lord Hailey, Native Administration and Political Development in British Tropical Africa, London, 1942

Elkins, Caroline, Britain's Gulag - The Brutal End of Empire in Kenya, 2005

Ferguson, Niall, Empire - How Britain Made the Modern World, London 2004

Good, Kenneth, 'Kenyatta and the Organisation of KANU', in Canadian Journal of African Studies, Volume 2, No.2, 1968

Greenstein, Frederick, Personality and Politics - Problems of Evidence, Inference and Conceptualisation, Chicago, 1969

House of Lords Debates, Tanganyika Independence Bill, Second Reading, Volume 235, $16^{\text {th }}$ November, 1961

Illiffe, John, A Modern History of Tanganyika, Cambridge, 1979 
Jackson, Robert and Rosenberg, Carl, Personal Rule in Black Africa, Prince, Autocrat, Prophet Tyrant, California, 1982

Judd, Dennis, Empire - The British Imperial Experience from 1765 to the Present, Scotland, 1996

Kariuki, J. M., Mau Mau Detainee, London, 1964

Kenyatta, Jomo, Suffering Without Bitterness, Nairobi, 1968

Kenyatta, Jomo, Facing Mount Kenya - The Tribal Life of the Gikuyu, London, 1961

Killingray, David, 'The Maintenance of Law and Order in British Colonial Africa,' in African Affairs, Volume 85, Number 340, 1986

Kirk-Greene, A. H. M., 'The Thin White Line: The Size of the British Colonial Service in Africa, in African Affairs, Volume 79. No. 314, 1980

Kurtz, Laura, Historical Dictionary of Tanzania, London, 1978

Lange, Matthew K, 'British Colonial Legacies and Political Development, in World Development, Volume 32, Number 6, 2004

Lonsdale, John, and Berman, Bruce, 'Coping with the Contradictions: The Development of the Colonial State in Kenya, 1895-1914, in The Journal of African History, Volume 20, Number 4. 1979

Machiavelli, Niccolo, The Prince, 1513, in Jackson, R., and Rosberg, C., Personal Rule in Black Africa, Berkeley, 1982

Murray-Brown, Jeremy, Kenyatta, London, 1972

Maslow, Abraham, 'A Theory of Human Motivation,' in Psychological Review, Volume 50, 1943

Meredith, Martin Diamonds Gold and War - The Making of South Africa, London, 2007

Meredith, Martin, The State of Africa - A History of Fifty Years of Independence, London, 2006

Mwakikagile, Godfrey, Tanzania Under Mwalimu Nyerere, Reflections on an African Statesman, California, 2004

Njoh, Ambe J., 'Colonial Philosophies, Urban Space and Racial Segregation in British and French Colonial Africa, in Journal of Black Studies, Volume 38, 2007

Nugent, Paul, Africa Since Independence - A Comparative History, New York, 2004

Nyerere, Julius, Essays on Socialism, Dar es Salaam, 1969

Nyerere, Julius, Ujamaa - Essays on Socialism, Dar es Salaam, 1968

Obituary of Michael Blundell, The Independent, $9^{\text {th }}$ of August, 2012

Ozkirimli, Umut, Contemporary Debates on Nationalism - A Critical Engagement, New York, 2005

Pratt, Cranford, The Critical Phase in Tanzania, 1945 - 1968, Cambridge, 1976

Scharma, Simon, A History of Britain - The Fate of Empire 1776 - 2000, Volume Three, London, 2002 
Smith, Alex Duval, 'Tanzania Weeps for Father of the Nation' in The Independent, $20^{\text {th }}$ October, 1999

Smith, William Edgett, Nyerere of Tanzania, Harare, Zimbabwe, 1981

Smith, William Edgett, We Must Run While They Walk - A Portrait of Africa's Julius Nyerere, New York, 1971

Tignor, Robert, The Colonial Transformation of Kenya - The Kamba, Kikuyu, and Maasai from 1900 to 1939, New Jersey, 1976

United Nations Development Program, Investment Policy Review - Kenya, 2005, http://mirror.undp.org/kenya/IPC\%20-FDI.pdf (Accessed 20.8.2012)

Urfer, Sylvain, Une Afrique Socialiste: la Tanzanie, Paris, 1976

Wepman, Dennis, Jomo Kenyatta, London, 1988

Willis, Justin, 'The Administration of the Bonde - 1920 - 60: A Study of the Implementation of Indirect Rule in Tanganyika,' in African Affairs, Volume 92, Number 366, 1993

'Jomo Kenyatta' in Encyclopaedia Britannica Academic Addition http://www.britannica.com/EBchecked/topic/315185/Jomo-Kenyatta (Accessed 12th August, 2012)

Julius Nyerere in Encyclopaedia Britannica Academic Addition http://www.britannica.com/EBchecked/topic/423105/Julius-Nyerere (Accessed 15th September, 2012)

'Tanganyika' in Encyclopaedia Britannica Academic Edition http://www.britannica.com/EBchecked/topic/582427/Tanganyika (Accessed 27th August, 2012) 